\title{
Guidelines for Coordinated Management of \\ Noxious Weeds \\ in \\ The Greater Yellowstone Area
}

\section{Table of Contents}

Section Title Page

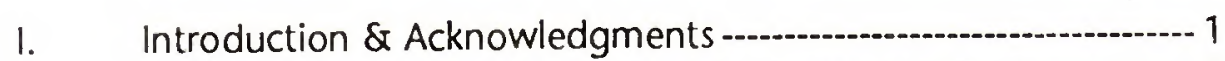

II. Purpose \& Organization of Weed Management Areas -...--..-.-.- 3

III. Awareness, Education, and Training -................................ 9

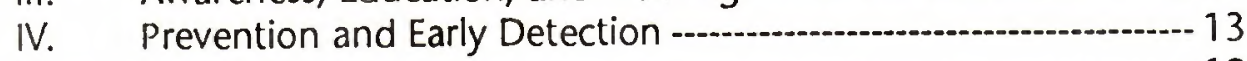

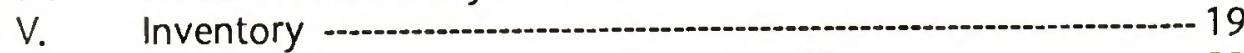

Vl. Management Plan / Annual Operating Plan -..--.-.-.-.-.-.-.-.---- 23

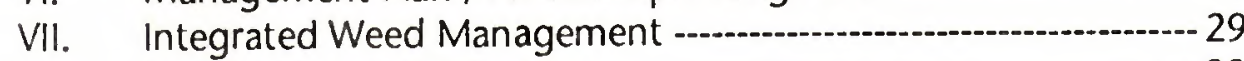

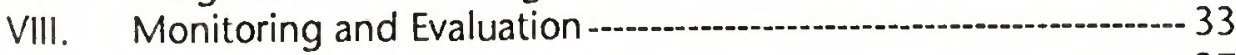

IX. Reporting - 37

X. Glossary and Abbreviations - 39

\section{Appendix}

1. GYA Memorandum of Understanding

2. List of Noxious or Exotic Weeds - County, State, Federal

3. List of Existing Laws, Regulations, and Policies

4. GYA Certification Standards

5. Guidelines for a Public Meeting

6. Noxious Weed Information Questionnaire

7. Reporting Forms

8. Monitoring Techniques

9. Noxious Weed Data Table

10. Site Information Worksheet

11. Guidelines for a Management Plan and an Annual Operating Plan

12. Guidelines for a Safety Plan

13. Guidelines for a Testing Program, Contract Clauses, and Closure Statements

14. List of WSSA Weed Names and Codes

15. List of Sources of Information

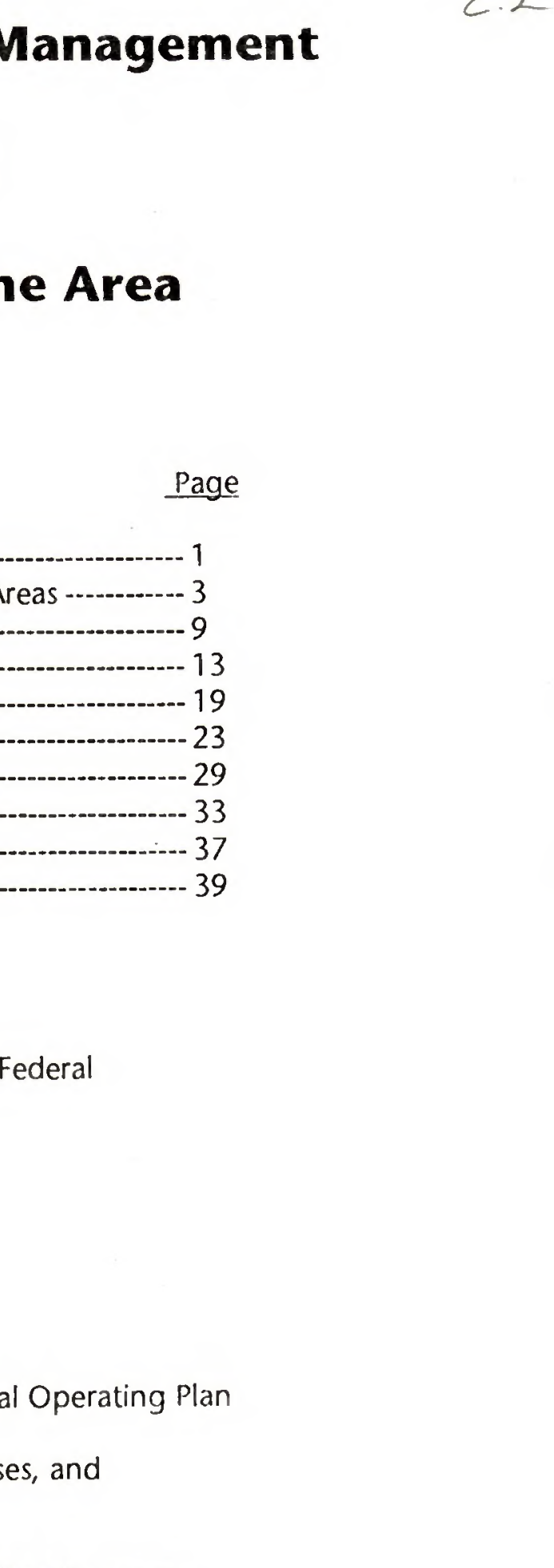

BLM Library

Denver Federal Center

Bldg. 50, OC-521

P.O. Box 25047

Denver, CO 80225 


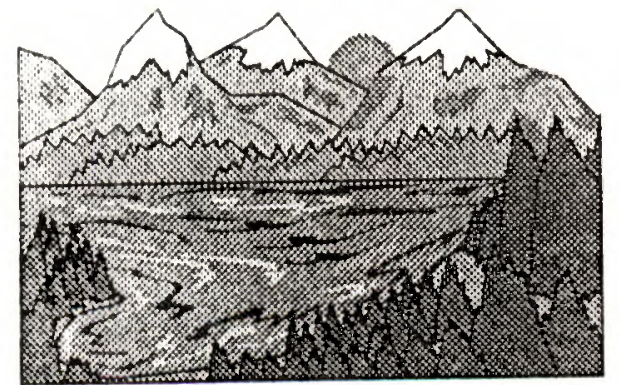

Weeds in the Greater Yeliowstone Area
World renowned for its renewable resources, this area offers outdoor recreation opportunities, scenery, geologic and thermal features, and it attracts millions of people annually.

\section{Section I}

\section{Introduction and Acknowledgments}

Undesirable plants are spreading into the Greater Yellowstone Area. Exotic plants and noxious weeds infest the native plant communities in increasing numbers throughout the area.

Public concern increases about the existing and potential harm. ful effects of unmanaged weeds. Unacceptable levels adversely affect crop and forage production, wilderness, wildlife habitat, visual quality, recreation opportunities, and land value. Land managers face the challenge to develop and conduct an effective program for controlling the spread of noxious weeds.

Seven National Forests and two National Parks comprise the GYA. The entire GYA encompasses 20 million acres that include the National Forests and the National Parks, federal reservations, plus state lands and parks, National Wildlife Refuges, Bureau of Land Management, Bureau of Reclamation, and private lands.

This area lies within three states -- Montana, Idaho, and Wyoming -- and includes all or part of 16 counties. World renowned for its renewable resources, this area offers outdoor recreation opportunities, scenery, geologic and thermal features, and it attracts millions of people annually.

A Memorandum of Understanding (Appendix 1) for Noxious Weed Management was signed by ail entities within the GYA to encourage and formalize the cooperative relationship necessary for effective management and coordination of Noxious Weed programs among the iand managers. This agreement will resuit in increased sharing of expertise, information, resources, and provide a process to improve the efficiency and effectiveness of ali weed management programs.

These guidelines provide a unified effort in developing a public awareness program; a prevention program; and a common inventory, mapping, monitoring, and reporting procedure. An overall Management Plan and specific action plans can be developed for logical units of land called Weed Management Areas.

The GYA can be divided into Weed Management Areas that have common characteristics and become the land unit for the 


\section{Section 1}

development of a Noxious Weed Management Plan. These areas replace jurisdictional boundaries in favor of natural boundaries that facilitate cooperation, coordination, and implementation of an integrated weed management program for noxious weeds. The County Weed Districts will be an important driving force in developing weed management programs for these areas.

Acknowledgments The following people contributed their expertise and technical guidance to develop "Cuidelines for Coordinated Management of Noxious Weeds in the Greater Yellowstone Area":

Jim Free, Chairperson

Range Management Staff

Forest Service, USDA

Rocky Mountain Region

Lakewood, Colorado

Barbra Mullin

Weed Coordinator

Montana Dept. of Agriculture

Helena, Montana

Hank A. McNeel

Weed/Pest Management Specialist

Bureau of Land Management

Billings, Montana

Robert R. Parsons

Supervisor

Park County Weed \& Pest Control District

Powell, Wyoming

James Sweaney

Supervisor Forestry Technician

Yellowstone National Park

Yellowstone N.P., Wyoming

Loal A. Vance

Weed Control Coordinator

Idaho Dept. of Agriculture

Boise, Idaho

Charles Henry

Ag West Communications

2305 Nottingham Ct.

Fort Collins, Colorado 


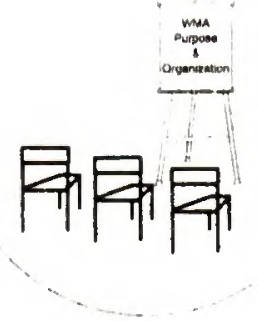

Part One Purpose of Weed Management Areas

Weed Management Areas (WMA) are distinguishable zones based on similar geography, weed problems, climate, or human-use patterns.

\section{Section II}

\section{Purpose and Organization of Weed Management Areas (WMA)}

The purpose of creating a WMA is to facilitate cooperation among all land managers and owners to manage a common problem with weeds.

The goal of a WMA is to prevent the reproduction and spread of weeds into and within the WMA. The formation of a WMA replaces jurisdictional boundaries that are barriers to weed management programs in favor of natural or more logical boundaries that facilitate weed management and control. A WMA will be an area in which one agency/landowner's weed management success will be largely determined by the cooperative efforts of other agencies or landowners in the area. The boundary of a WMA will usually be a hydrographic divide or vegetational zone boundary.

\section{How the WMA Concept Works}

The WMA enhances and unites individual ownerships or jurisdictions that form the land unit for mapping, planning, monitoring, and conducting weed programs. Cooperators in a WMA jointly prioritize weed management efforts based on species or geographical area. Cooperators then work together to manage the weeds within the WMA.

It is possible that most or all of the control effort within the WMA will take place on land managed by one agency/landowner. Based on the species or geographic priority, it may be several years into the plan before control actions take place on some jurisdictions.

As an example: if one county has a rapidly developing lealy spurge infestation and a neighboring county's only weed problem is woolly mullein in an abandoned gravel pit, it may be beneficial to both counties to pool their resources to control the spurge before going after the mullein. If individual landowners desire to continue to do their own control work, a joint planning, analysis, and monitoring program would still be efficient; and individuals might alter their priorities to coordinate the control of an infestation that spans a common boundary. 


\section{Section II}

The plan results in the greatest good for the entire WMA in the long run. Planning establishes priorities.

Under the WMA plan, a Iandowner or jurisdiction can address the problem of weeds spreading from neighboring land before the damage occurs.
A WMA may be weed-free and organized to quarantine an area from importation of weeds. The landowners may agree not to allow the use of hay from outside areas. They may agree to require that any construction, utility, logging equipment, etc., coming into the area be weed-free.

Always include county weed boards in the WMA even if only federal land is involved. The WMA does not supplant the county weed board, but insures that cooperation extends across county, state, and federal boundaries within the Greater Yellowstone Area.

\section{Advantages of cooperating in a Weed Management Area:}

1. It encourages cooperators to plan through the problem to its successful resolution.

2. The plan results in the greatest good for the entire WMA in the long run. Planning establishes priorities.

3. Cooperators can locally prioritize and give emphasis to species of a particular threat within individual WMAs.

4. The designation of a WMA by diverse individuals and agencies focuses attention and provides a united front to state and federal legislators. It also communicates to the general public the seriousness of weeds by increasing awareness of the weed and the need to contain or prevent infestations.

5. AWMA pools talents and resources. For instance, WMAs enable one agency to contract with another for its weed control.

6. Under the WMA plan, a landowner or jurisdiction can address the problem of weeds spreading from neighboring land before the damage occurs.

7. AWMA provides a channel for communication within the WMA.

8. It reduces the risk of damage by control actions to water, crops, Threatened \& Endangered (T\&E) species, etc.

9. The formation of a WMA increases the effectiveness of weed management by basing control efforts on biological and geographical factors rather than legal divisions.

10. Designation of a WMA helps secure funding or identifies a method for funding. 
11. The creation of different management zones within the WMA fits the most effective and environmentally sound weed management and control practices to each zone.

12. A well-written and implemented plan within the framework of a WMA addresses the following potential concerns:

A. A private landowner or agency may relinquish some individual autonomy. Everyone gains efficiency and increases their ultimate success by participating in a WMA.

B. An individual's or agency's priorities may differ from the WMA's priorities. Individual priorities are usually best served and success is greatest when managed within the context of the entire WMA's priorities.

C. The weed prioritization and planning process created by a WMA insures that one jurisdiction or agency cannot dominate.

D. By involving representatives from all diverse interests within a WMA, residents of one jurisdiction -- a county, for example, -- better understand why their weed treatment crews spend time working in a different county, or on Forest Service land.

Part Two

How to Organize a Weed Management Area (WMA)
A. Any weed control district, agency, or individual may take the lead towards initiating a WMA.

B. Consult with weed management specialists for ideas.

C. Initiate a planning (or inter-agency) organizational meeting. 1. Invite representatives from all management agencies within the perspective WMA.

2. Invite principal landowners or representatives from key landowner groups (sports clubs, wildlife organizations, stockgrowers, conservation district, etc.).

3. Keep the number of representatives from each agency or local interest to a workable minimum. 


\section{Section II}

4. To assure good attendance by the agencies and individuals involved, set time and place of meeting to compensate for seasonal work schedules, community-school events, and holidays.

D. Select a steering committee to initiate the next stages of organization.

\section{Objectlves of Initial WMA A Organizatlonal Meeting(s)}

The tollowing oblectives can blso serve as the ag enda for your organizational and publtc meetings.

A. Establish clearly defined boundaries coordinated with other WMAs.

1. : Boundaries of a WWA nay be created according to. watersheds, topography, weed species, land usage, and for rights of way.

2. : : identify prelininary specialmanagement zones within the WMA such as:
a. . . Avatic areas
b. : : Threatened o endanger ed species habi: lat or spectes of special concern
c. : : . Recreationallspecial use areas
d. : : transportation corridors - rights of way. nay need 10 be ex choded from the WMA or treated as a separate WMA.

B. . Select a leader champerson

1. : : Select leader based on the abiltites, interest, and qualifications, not 0 n agency bias.

2. . . Allow chaifperson access to office tacilties and personnet to insure completion of communica. tions and reports.

c. . Review funding ard avalable resources.

1. : : Discuss available funding and establish accounting guidelines.

2. Review obtaining additional funding if neces sary.

3. Review nanpower and time capabilities of individuals and agencies within the WMA.

D. . Review appropriate state weed laws and agency weed regulations and polices. (Ses summaries in Appendix 3)

E. Set date, time, and place for public neeting to allow. input from all individuals within the WMA.

F. . set arget dates for completion of different steps of the planning process. 


\section{Section II}

\author{
II. Initial Assessment by \\ WMA Steering Committee
}

A second meeting of the steering committee may be required. This step in the process is critical to determine what is known, and what information is missing.
A. At this stage, accurately evaluate the level of noxious weed awareness, and the existence or status of noxious weed mapping, inventory, or prevention programs in the weed management area.

B. A second meeting of the steering committee may be required. This step in the process is critical to determine what is known, and what information is missing.

C. It is important to make this assessment at this stage in the organizational process for several reasons.

1. This assessment helps predict the expected level of involvement of the residents, landowners, and other agency personnel in weed management planning and the management process.

2. The results of this assessment can determine initial weed management objectives. For instance, rather than treat weeds first, it is usually most effective to establish awareness and prevention programs first.

3. The assessment can provide answers to questions that may arise at the first public meeting. Your credibility and the potential value of an established WMA increase when you can correctly and concisely answer such questions as:

Do we have a weed problem? What does it cost us?

- Can we keep weeds out or prevent their spreading in the WMA?

- What weed species predominate in our WMA?

- Where do weed infestations exist in the WMA?

- Is there a weed prevention program in place?

Why is weed management important?

- How do weeds impact recreation, wildlife, fish, forestry, etc.?

4. Once you know the level of awareness in the WMA, the public meeting discussed in Part III can be utilized to collect additional needed information.

III. Detaiis of A Public A.
Meeting

Use all forms of publicity to inform everyone who might be affected or interested in the WMA.

B. Use a model for conducting a public meeting (See Appendix 5).

C. Ask the attendees to complete a Noxious Weed Information Questionnaire (See Appendix 6). 


\section{Section II}

D. Review the GYA coordinated weed management concept with the participants.

E. Explain the planning process, mapping, WMA concept, and other information in the planning meeting.

1. Be willing to modify initial objectives based on input from the public meeting.

2. Because of various barriers, even the proposed boundaries of the WMA may need changing.

F. Identify weed problems

1. Consider whether weed problems are a localized concern or a true threat to the entire WMA.

2. Properly identify the weed so there is no misunderstanding of what plant is considered a problem.

3. Provide a large scale map of WMA and use it to record infestations.

G. Clearly state that integrated weed management practices must be followed in the WMA (See Section VII, "Integrated Weed Management").

H. Record all ideas for future consideration.

1. Make adjustments in the membership of the planning/ working committee.

J. Obtain mailing addresses and mail results of Questionnaire and Management Plan to attendees.

IV. Writing a WMA Plan

A. The planning/organization committee drafts the WMA Management Plan after the public meeting.

B. Review the draft with all interested individuals before finalizing the Management Plan and development of the action plan.

C. Allow for changes or modifications in the Management Plan as conditions change. (See Section VI, "Management Plan/Annual Operating Plan") 


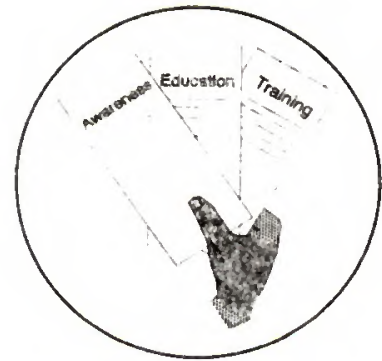

Education on the impact of noxious weeds to critical flora and fauna of the area is an important facet of any long-term weed management plan developed.

\section{Section III}

\section{Awareness, Education, and Training}

Awareness of what noxious weeds are and the problems they cause will help the general public to understand why a long-term program is important for the Greater Yellowstone Area (CYA). Education on the impact of noxious weeds to critical flora and fauna of the area is an important facet of any long-term weed management plan developed. All Federal, State, and local agency personnel, as well as private landowners involved in the management programs, must have proper training, licenses, and certification in the correct use of weed management techniques. The primary groups to be targeted by an awareness, education and training campaign are WMA residents, visitors, and Federal and State land management agency staff, both permanent and seasonal.

Exotic plants pose a serious threat to the native vegetation of the GYA. The invasive nature of most exotic plants that are considered noxious weeds makes it imperative that agency personnel working in the area are familiar with the most important noxious weed species and the damage they cause.

CYCC Education \& Awareness Objectives

Development of area-wide informational brochiries, educational and public awareness materals and training coord: nation is the responsibility of the Greater Yellowstone Coordinating Comnitree ( OKCC)

it is the tesponstbitty of each Weed Managenent Area steering conmittee to obtaln at infor mation on the weed managentent and awareness program availabie from the GYCC. EVery WMA can distibute this information through various areas within the WMA such as:

National Pats Entrances

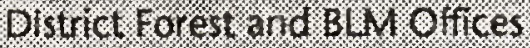

Visitior centers.

Park and National Torest Campfire and Trall Pro. grams

County Extension Ofinces

Area Chambers of Commetce

Local Touns

Local Widlite Organizations

Schools and Senice Organizations 


\section{Section III}

I. WMA Awareness and Education Objectives
A. Develop general public awareness programs outlining problems caused by noxious weeds, including:

1. Damage to wildlife habitat and crop and forage protection.

2. Impacts of health problems associated with weeds, including skin irritations and allergies.

3. Impact on scenic and recreatlonal values.

B Utilize GYCC sources and materials when available.

C. Develop and maintain demonstration plots which would:

1. Be in areas frequented by visitors

2. Illustrate the impact of different management techniques and treatment obtained in infested areas

3. Include information on:

a. The effectiveness of biological weed control (the establishment of an insectary would be beneficial).

b. The impact of pulling and mowing noxious weeds.

c. Herbicide treatments showing grass and forb response, including information on safe handling of herbicides, actual amount of herbicide applied to the area, and other environmental concerns.

d. Explanation of why each method of control is an acceptable choice for that specific area.

D. Develop annual tours to:

1. Update local area residents on the progress of noxious weed management within the GYA.

2. Update agency personnel on the results of management programs.

E. Develop and maintain displays and programs on selected noxious weeds to supplement those provided by the GYCC.

F. Encourage creativity by sponsoring an annual "new weed management idea" program in your WMA to increase weed awareness.

II. State and Federal Agency Education and Awareness Objectives
A. Follow GYCC Education and Awareness Objectives.

B. Assign one staff person to administer weed management plans for that agency and for each WMA. This person should have specific training in weed biology and integrated control systems, with formal education (such 


\section{Section III}

III. WMA Training Objectives

\section{Implement a regular education and training program to ensure that all cooperators maintain proper certification throughout the life of the project.}

as a weed management short course) or specific training from qualified experts.

C. Provide and support local training workshops for permanent and seasonal staff. It is essential to utilize resource people outside of the agencies for inter-agency training. These workshops should include:

1. Specific information on weed identification and biology

2. Basics of integrated weed management (IWM) and control options

3. The importance of prevention strategies within the GYA, and

4. Efficacy expected from management options chosen for an area

D. Establish local staff programs to identify all important weed species and to report infestations discovered to the lead staff member. Special incentives (such as extra compensatory time) to individuals who submit this information could be used to encourage participation by general staff members.

A. Develop cooperative training programs to educate and inform all participants in the WMA about the latest Integrated Weed Management options and technologies. These programs should include all land managers within the WMA, including state and federal agency land managers, as well as private landowners.

B. Develop a training program in cooperation with the Cooperative Extension Service and other agencies that ensures that all weed management techniques follow approved procedures, including proper use of all herbicides and calibration of application equipment.

C. Implement a regular education and training program to ensure that all cooperators maintain proper certification throughout the life of the project.

D. Sponsor training programs for private landowners to ensure proper pesticide use. Resources to provide training can include: weed district personnel, county extension agents, and university and agency personnel. Training should include:

1. Weed identification

2. Integrated weed management concepts (See Section VII - Integrated Weed Management)

3. Implementation of management techniques 
4. Proper selection of the most effective weed treatment technique

5. Pesticide safety equipment

6. Proper pesticide storage

7. Application equipment calibration

8. How to develop a weed management area (See Section II,"Purpose and Organization of Weed Management Areas")

9. How to develop a Management Plan and Annual Operating Plan (See Section VI, "Management Plan/Annual Operating Plan).

\section{NOTES:}




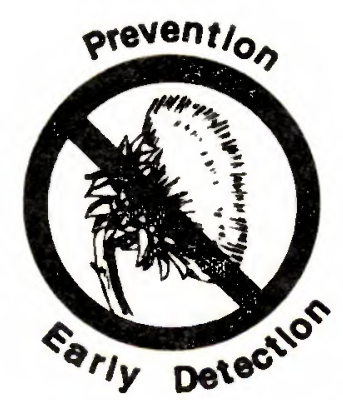

-
I. Early Detection and Eradication Requirements To Be Used In the GYA and Implemented in Each Weed Management Area

\section{Section IV}

\section{Prevention and Early Detection}

Prevention, early detection, and eradication of early detected noxious weed species are the most practical means of weed management. Prevention is best accomplished by ensuring that new weed species' seed or vegetative reproductive plant parts are not introduced into an area. Common methods of introduction include:

a Contaminated seed, feed grain, hay, straw or mulch

- Movement of uncleaned equipment or machinery from a noxious weed-contaminated area to a noncontaminated area. This includes equipment or machinery used for or by construction, recreation, agriculture, forestry, oil and gas exploration and production, utility companies, mining, and tourism.

a Animals (domestic and wildlife) that have viable weed seed present in their digestive tract or attached to their hair or wool.

a People scattering wild bird seed contaminated with noxious weed seeds, noxious weed plant parts with viable seed, or planting noxious weed seed for ornamentals.

Allowing noxious weeds to produce seed along waterways.

using gravel, roadfill, or top soil contaminated with noxious weed seed or vegetative reproductive plant parts.

Early detection Is Identifying and documenting newly introdiced weed specles into an area.

Eradication is emplaying appropriate narigge. ment methods to totally remove infestations: including reproductive potentivl of a weed spedies in an area.

A. Develop early detection methods and eradication programs for new invaders. This would include education and awareness programs where visitors and users of the area assist managers in locating and identifying new invader weed species.

B. Provide follow-up inspection to verify potential of new invader weed species. Initiate an eradication program if new invaders are confirmed. 


\section{Section IV}

II. Prevention Requirements

To Be Used In the GYA and Implemented in each Weed Management Area

a. Limit all public lands in CYA to the use of processed or certified weed-free feeds.

b. Develop stipulations that will not allow any importation of weedcontaminated hay or processed feeds through the GYA.

c. Develop certification standards or a quarantine program to ensure the production and use of weed-free hay and other agronomic crops in the WMA.
Following are specific recommendations for the prevention and early detection of the spread of the noxious weeds. More stringent guidelines may be necessary in certain parts of a WMA. Example: within National Park or wilderness areas. (See Section X, "Glossary and Abbreviations" - listing "Certified Weed-Free') See Appendix 13 for samples of testing programs, contract clauses, and closure statements that apply to the prevention requirements below.

A. Ensure that seed, feed grains, hay, straw or mulch are free of weed reproductive plant parts and meet standards set in the GYA Certification Standards for Feeds (livestock and wildlife), Mulches, Bedding and Re-seeding materials. (See Appendix 13)

1. Seed

a. Seed should be certified and tested for noxious weed seed at a state seed laboratory.

b. Develop clauses for revegetation plans of disturbed sites that include reseeding with weed-free seed.

2. Mulches

a. Develop contract clauses that do not allow any seed or reproductive plant parts present in mulch.

b. Certify mulch samples to meet GYA Certification Standards prior to any placement of the mulch in the area.

3. Certified hay or processed feeds

a. Limit all public lands in GYA to the use of processed or certified weed-free feeds.

b. Develop stipulations that will not allow any importation of weed-contaminated hay or processed feeds through the GYA.

c. Develop certification standards or a quarantine program to ensure the production and use of weed-free hay and other agronomic crops in the WMA.

B. Encourage proper management of livestock used in or trailed through the WMAs to slow noxious weed spread. 1. Use only feeds meeting GYA certification standards. Processed feeds inhibit the germination of weed seed and kill the vegetative plant parts. Pelleted feeds also reduce waste lowering the potential spreading of weed-contaminated feed. 


\section{Section IV}

Develop an Integrated Weed Management Program whereby all landowners within the WMA are working in a cooperative program that prevents weeds from producing seed.
2. Livestock used in cultural management of weeds should be held in a weed-free environment 96hours prior to moving them into the WMA. This allows the animals to clean their digestive tracts of weed seeds.

C. Ensure that equipment or vehicles are free of weed reproductive plant parts prior to movement into the WMA. Develop standards and follow proper guidelines to prevent the introduction of weeds by equipment or machinery used for or by:

Agriculture/Livestock

Commercial and Private Construction

Fire Suppression Measures

Geothermal Exploration/Production

Irrigation Ditch Companies

Mining and Quarries

Oil and Gas Exploration/Production

Range and Wildlife Improvement Projects

Recreation/Tourism/Hunting/Fishing

Right-of-way Construction/Maintenance

Timbering and Forestry

Utility Construction/Maintenance

1. Develop cooperative weed-prevention programs with the suppliers of sand, gravel, top soil, and other construction materials to ensure that these materials are free of weed seed or reproductive plant parts before quarrying, mining and/or transporting within or into the WMA.

2. Develop stipulations in the contracts that do not allow any weed seed present in the gravel or other material.

3. Develop clauses in timber sales contract that set standards on revegetation, weed-free seed and mulch, operation practices, etc.

D. Educate people to the variety of seed transport methods:

1. Picking and transporting plants or parts of plants, such as flowers, may spread noxious weed seeds.

2. Weed seeds may stick to clothing when walking through weed-infested areas.

E. Work with the county and city planning staff and zoning committees to include consideration for noxious weed management when developing or approving subdivision plans, special use permits, or new leases. 


\section{Section IV}

III. Fire Suppression and Site A.
Rehabilitation Plans

Fire suppression activities may contribute to invasion by noxious weeds. During and after a fire, firefighters, material, and equipment are brought in from all areas of the country and deployed throughout the fire, possibly dispersing weed seed.
F. Develop an Integrated Weed Management Program whereby all landowners within the WMA are working in a cooperative program that prevents weeds from producing seed.

G. Develop weed-awareness programs for local residents, fishing and hunting license-holders, the visiting public, and staff members of the different county, state, and federal agencies (See Section III, "Awareness, Education, and Training').

H. Develop cooperative agreements with enforcement agencies to assist in the prevention of introduction of weed species into the area.

Fire suppression results in the disturbance of land surface by vehicles, foot traffic, packstock, chemicals, helicopter buckets, bulldozers, fireline explosives, pumps, and handtools. In the GYA this disturbance occurs in the remote areas that would not otherwise be subject to the introduction of weeds, and where infestations are not likely to be detected following the fire. Fire rehabilitation practices may include seeding the firelines or burned area with exotic plants which are often contaminated with noxious weed seed.

B. The direct effects of the fire on potential weed problems varies. Most of our serious weeds are shade-intolerant invaders. The stand replacing fires common in the GYA results in large areas of the forest floor being exposed to sun for several years following the fires. There are, however, a complement of native plants such as fireweed, lodgepole pine, and many others that are equipped to take advantage of fire and vigorously occupy a burned site. These natives may outcompete Eurasion invaders that are not specifically adapted to fire.

C. Planning before fires occur can mitigate the impacts of noxious weeds during and after fire suppression activities.

\section{To minimize weed impacts:}

1. Approve noxious weed management actions that utilize the most cost-effective means of providing adequate watershed cover where competition from noxious weeds would render emergency revegetation of firelines and campsites ineffective. This includes setting standards in the fire plan that only weed-free seed is used for revegetation. 


\section{Section IV}

Require the cleaning of equipment and packstock used on the fireline and in

camp. This includes the development of proper cleaning methods of all equipment to be used on fires to reduce the possibilities of the spread of weed species.
2. Use chemical suppression in conjunction with reseeding only where on-going NEPA approved noxious weed control activities are underway. Approved supplemental treatment may be applied if completed prior to 1 year from initial approval of emergency action. The same considerations apply to rehabilitation of severely burned areas under FFF emergency burned area protection authority.

3. Where noxious weeds are a problem but no approved chemical control actions are underway, emphasize timely seeding of herbaceous cover species that will aggressively occupy disturbed sites until recovery by native plant species occur. Use drilling or other effective techniques to gain a high rate of plant establishment.

D. To prevent the invasion of weeds into burns:

1. Weed prevention will be a consideration in the daily fire-fighting operation.

2. Consider rehabilitation as part of the suppression effort. The planning section should address prevention in the rehabilitation plan.

3. Emphasize light-hand tactics to minimize the amount of soil disturbance.

4. Require the cleaning of equipment and packstock used on the fireline and in camp. This includes the development of proper cleaning methods of all equipment to be used on fires to reduce the possibilities of the spread of weed species. Example: Provide and use pressure cleaning equipment for use on all fire suppression equipment.

5. Avoid staging equipment and resources in weedy areas.

6. Consider the ecological and economic costs of potential invasion by weeds in the escaped fire analysis and the possible benefits of the contain and confine options. Aggressive suppression may result in the least amount of land disturbed by fireline and camps. The cheapest option will probably result in the least disturbance.

7. Use only seed that is certified weed-free.

8. Avoid seeding burned areas as much as possible. 
9. Restore firelines using the same material that was removed during construction.

10. Replant with native materials.

11. Replace top soil/sod immediately after fire is out. 12. Use aircraft rather than packstock.

E. In the GYA where timber values are low and wildife and recreational values are high, consider the beneficial effects of fire and the damage done by suppression activities, including the spread of weeds, when formulating long range plans. A decrease in diversity and the increase in old communities, fuel accumulation, and the intensity and the size of fires resulting from successful fire suppression programs may eventually increase the susceptibility of the GYA to invasion by weeds. 


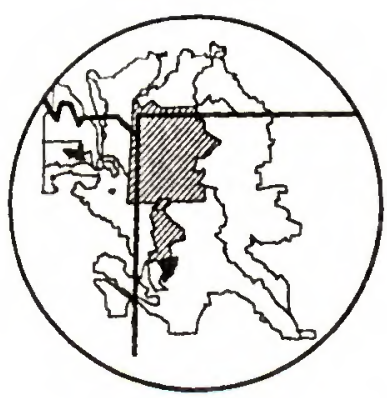

I. Mapping

WMAs are land units that have similar characteristics such as geography, weed problems, climate, or common interest and funding support. Boundaries will usually be a hydrographic divide which takes in a large watershed.

\section{Section V}

\section{Inventory}

Inventorying is one of the most useful parts of any noxious weed management program. You must know "what is out there" if you expect to manage your weed problems successfully. Agood inventory and mapping system: 1) clearly defines the problems; 2) brings awareness both visually and statistically; 3 ) is a tool used to develop prevention and IWM action plans; and 4) monitors the program effectiveness.

See sample map at end of this section.

A. Weed Management Areas will be established for the entire GYA. These areas will be established through coordination between the County Weed Districts and the Agency personnel. WMAs are land units that have similar characteristics such as geography, weed problems, climate, or common interest and funding support. Boundaries will usually be a hydrographic divide which takes in a large watershed. This eliminates jurisdictional boundaries that are barriers to weed control in favor of natural boundaries that are barriers to the spread of weeds.

B. Complete noxious weed management maps and an inventory of the weeds in Weed Management Areas.

1. Base maps will be USGS 1:24,000 topographic maps or Orthoquad maps. When these are not available, other maps that define the information needed may be used.

2. Certain features should be common to all noxious weed management maps. Use clear overlays to show additional features. The base maps should show, or you should be able to mark on them the following information:

a. weed infestations by species.

b. topographic features.

c. roads, trails, power lines, railroads, irrigation canals and ditch systems, jurisdictional boundaries, cropland, etc.

d. vegetation types, soils, groundwater.

C. In some situations weeds may infest a site (or sites) that crosses already established jurisdictional lines. For example, a large patch of weeds could infest Forest Service land and adjoining National Park or private land. 


\section{Section V}

II. Infestation location, acreage estimate, and level (density) of infestation by species
Individual jurisdictions may require reporting on the acres and severity of weeds only on their portion of a given site. For example, the Forest Service may want to inventory only their lands for weeds.

Therefore, when inventorying noxious weed in festation sites within a WMA, include the following de lineations to aid individual jurisdictions in their reporting requirements:

1. Jurisdictional boundaries (National Parks, National Forests, Bureau of Land Management, Administrative District Boundaries, etc.)

2. Ownership boundaries

3. State and county lines

4. Relatively permanent, administratively or legally classified areas boundaries (RNA, wilderness, experimental Forests, Administrative sites, etc.)

5. Other optional boundaries that should be consid. ered are: Range Allotment boundaries, Land Management Planning boundaries, soil series, vegetation types, roadways.

A. Procedure

1. Map infested acres using the following symbols on the mapped area to indicate the approximate size and location of the infestation. Five-letter WSSA codes will be used to indicate the weed species (Appendix 14). Color codes may be used on local maps to make the infestations more visible.

a. Keep an accurate list documenting areas surveyed where no weed infestations were found:<smiles>C1CO1</smiles>

b. Less than one acre: $\triangle$

c. One to five acres:

d. Greater than five acres:<smiles>C1CC2CCCC2C1</smiles>

2. Estimate of infestation level (density): Iss the following symbols to indicate infestation level (density).

a. $\quad L=L O W$ : Occasional plant per acre, iess than 5 percent canopy cover 


\section{Section V}

The use of a good mapping system will tell you the most about your land and the weeds out there. Mapping also gives you an historical weed infestation record so you can easily assess the success of your weed control program.
B. Discussion

b. $\quad M=$ MODERATE: Widely scattered plants, 5-25 percent canopy cover

c. $\mathrm{H}=\mathrm{HIGH}$ : More dense, 25-100 percent canopy cover Example: $4 \mathrm{M}=4$ acres of moderately CENMA dense spotted knapweed

1. Develop an inventory that addresses vegetation, site characteristics, and history status for the area. It helps you visualize your total weed problem, not just the one or two areas where you currently feel you have a problem.

2. The use of a good mapping system will tell you the most about your land and the weeds out there. Mapping also gives you an historical weed infestation record so you can easily assess the success of your weed control program.

C. Baseline Information

1. A good inventory of baseline data provides the manager data to evaluate weed management options. (See Appendix 9 for a data table that was developed to assist the land manager and should be completed for each infested site.)

2. There is tremendous value in having a computer to help chart progress and assist you in budgeting an effective multi-year plan. The advantages of a computer include uniformity of data entry, better organized information storage, and easy retrieval of data. A computer can also be used to monitor infestation trends and treatment and can be used as a planning tool. 


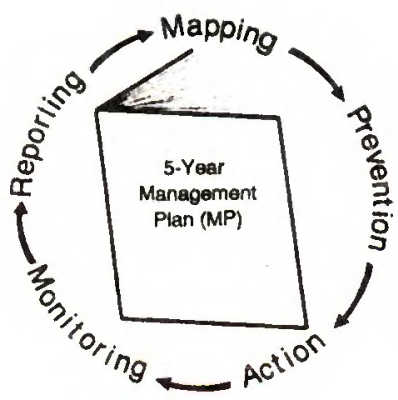

Manage Annual Operating Plan (AOP)

The Management Plan is the guiding document for each Weed Management Area. It is developed after the steps outlined in Section II, "Purpose and Organization of Weed Management Areas, Part Two", are completed.

heter to Appendl. 17 for

Management otan examples.

Section VI
The Management Plan

(MP) is considered the overall, long-term plan for the WMA. Ideally, its objectives address weed management for at least five years or longer.

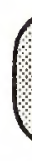

A. Define/Describe the WMA

(See Section V, "Inventory", for developing the following information)

1. Name and legal description

2. Describe boundaries

3. Describe land use -- timbering, recreation, grazing, farming, mining, etc. Be specific. List crops, domestic animals, visitor days for each recreational use, wood species timbered, etc.

4. Describe topography, major aquatic features, other natural resources

5. Describe wildlife and flora

6. Describe endangered species and species of special concern

7. Identify major towns, cities, resorts

8. Identify archaeological and Native American cultural sites

B. Define Purpose of WMA Management Plan

1. Describe long-term goals, objectives, and methods for controlling noxious weeds in this Weed Management Area.

2. Identify funding and resources for weed management.

3. Establish cooperation with residents, landowners, agencies, towns, organizations, counties, and states to effectively implement programs of prevention and control within the WMA.

4. Coordinate with other WMAs in the Greater Yellowstone Area.

C. Define WMA Policy

1. Commitment to cooperation

2. Commitment to use of Integrated Weed 


\section{Section VI}

Establish adherence to management of noxious weeds in accordance with CYA priorities as follows:

1 -- Prevention of potential invaders

2 .. Control of invading species new to a particularpart of the WMA 3 .- Management efforts on established stands
Management methods (See Section VII "Integrated Weed Management")

3. Establish adherence to management of noxious weeds in accordance with GYA priorities as follows:
a. $\quad$ First -- Prevention of potential invaders
b. Second -- Control of invading species new to a particular part of the WMA
c. Third -- Management efforts on estab- lished stands

4. Commitment to comply with all NEPA policies for at least 5 years

D. Define Long-Term WMA Objectives

Objectives should answer the needs of individual WMAs and may not need to address all aspects of noxious weed management listed here. Also, the need for and prioritization of the following objectives will vary between WMAs. It is important to consider each of these objectives, as success is greatest when an integrated plan is developed and implemented.

1. Develop and maintain an inventory

2. Develop and maintain funding and administration

3. Develop awareness, education, and training

4. Develop prevention and early detection programs

5. Develop long-term management objectives for weeds of concern, according to GYA prioritization (See \#5 below)

6. Develop and maintain monitoring and evaluation

7. Develop and maintain a reporting system

E. Identify WMA Weeds of Concern

1. List weed species and acres infested

2. Describe methods of introduction

3. Describe most likely areas of future infestations

F. Define WMA Roles and Responsibilities

1. List agencies and jurisdictions involved

2. Identify signatures required

3. Define planning timetable

4. Define terms and time of termination if applicable

5. Define insurance/liabilities

G. Define WMA Collection and Management of Funds

1. Consider budgeting methods 
Section VI

\section{Guidelines for Developing an Annual Operating Plan}

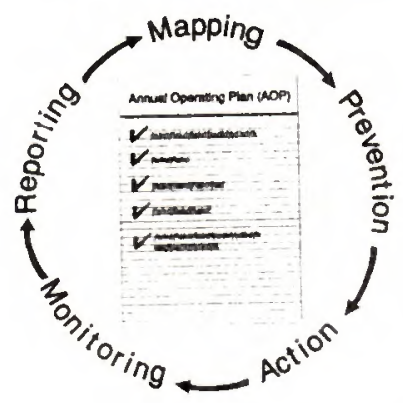

The Annual Operating Plan (AOP) addresses how, on an annual basis, the objectives of the overall Management Plan are implemented. It may not address all the objectives of the MP in a given year. This section will detail how to write a

Management Plan and an Annual Operating Plan. To distinguish between the two, remember, the MP addresses long-term (5 years or more) objectives and the AOP addresses annual objectives.
2. Determine fund management responsibilities

a. Determine whether WMA needs its own account

b. Determine administrative costs
The Annual Operating Plan (AOP) addresses how, on an annual basis, the objectives of the overall Management Plan are implemented. Due to manpower, funding, or other limitations, it may not be possible for the AOP to address all the objectives of the Management Plan in a given year. The Management Plan must set year-to-year priorities. The Annual Operating Plan guides implementation of the Management Plan in yearly increments.

Budgets and circumstances may change from year to year and these changes are best addressed in making new Annual Operating Plans, rather than rewriting the Management Plan annually.

An AOP may be developed for different management zones within the WMA. These zone-specific plans should be utilized only if they enhance weed management and control effectiveness and efficiency. For instance, a specific AOP may be necessary to manage only roadside weed problems within the WMA.

Refer to Appendix 11 for an Annual Operating Plan example. Review WMA and refresh yourself on your long-term objectives.

A. Define Roles and Responsibilities

1. List agencies and jurisdictions involved

2. Define signatures required

3. Define planning timetable

4. Define terms and time of termination if applicable

5. Define insurance/liabilities

B. Define Agreements and Compliance

1. Voluntary agreements: compliance of all land managers with district management standards.

2. Written agreements in intensive management areas may be needed.

3. Written agreement with landowners for control of noxious weeds along roadways

4. Procedure for non-compliance must be followed where applicable. 
5. Cooperative agreements (See Appendix 13)

a. Include: state agencies, municipalities, federal agencies, railroads, power company, others

b. Should only include listed noxious weed species

6. Revegetative standards and guidelines: written plan specifying methods for accomplishing revegetation, timing, methods.

7. Cost-share programs: noxious weeds only.

a. County commissioners and weed board should set standards for cost-share.

b. Cost-share programs for the district may differ from those designed for special projects areas.

c. Examples: district supplies chemical, district supplies labor, $50 \%$ of chemical cost, chemical supplied for drainage project areas, etc.

C. Define Annual Funding and Resource Availability

1. Determine sources of funding

2. Determine amount of funding

3. Determine sources of other resources

4. Determine amount of other resources

D. Define Proposed Actions to Meet Annual Objectives

1. Develop and maintain an inventory (See Section $V$ for guidelines)

a. Define areas for mapping and inventory

b. Determine who will be responsible

c. Determine manpower and funding required

2. Develop prevention and early detection programs (See Section IV for guidelines)

a. Define activities needed

b. Determine who will be responsible

c. Determine manpower and funding required

3. Develop awareness, education, and training (See Section III for guidelines)

a. Define activities needed

b. Determine who will be responsible

c. Determine manpower and funding required 
4. Develop an IWM system for the weeds of concern (See Appendix 11)

a. For each target weed:

1. Determine short-term IWM objective and methods

2. Describe reference materials to be used in determining IWM methods

3. Describe biological control agent if used for this weed

4. Describe pesticides if used for this weed

b. Determine who will make control recommendations

c. Describe safety precautions to be implemented

d. Determine who will implement treatment program

e. Determine manpower and funding required for control

f. Determine corrective measures to prevent recurrence of weed infestation

5. Develop and maintain monitoring and evaluation for all targeted weeds and according to Management Plan priorities and objectives (See Section VIII, "Monitoring and Evaluation" for guidelines).

6. Develop and maintain a reporting system for all proposed actions according to Management Plan priorities and objectives (See Section IX, "Reporting" for guidelines).

\section{Notes:}




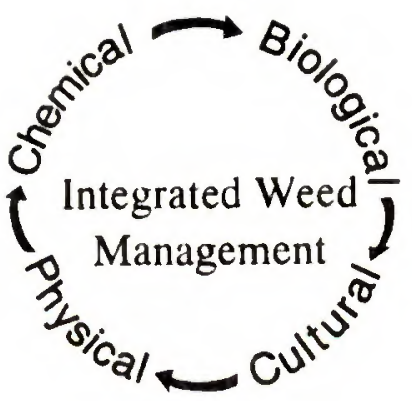

IWM is based on the fact that combined strategies for weed management work more effectively than a single strategy.

I. Cultural

\section{Section VII}

\section{Integrated Weed Management (IWM)}

Use the following guidelines to implement and determine the best method or methods for an integrated approach to weed management.

Integrated weed management is based on four general categories of management options (i.e., cultural, physical, biological, and chemical).

IWM is a decision-making process based on site-specific information on which decisions about treatment choices are to be based.

\section{No Action}

Before any optlions are considered, determine if no action is a viable solution. No action may be the correct culturat option if the following conditions exlst for a spedific site:

1. The problen will disappear without any action (e.g. annuals on newly disturbed areas).

2. Pollcles and laws prohilbit action

3. The general public prohibits action

4. The presence of threatened and endangered (T \& E) species or habitat for T \& E specles prohibits action

5. Aquatic or other site factors prohibit action

A. Prevention

1. Develop available preventive measures, such as quarantine and closure, to reduce the spread of the infestation.

2. Determine whether policy and laws allow for the use of all preventive measures, including local quarantine and closure.

3. If past management activities have allowed the introduction and spread of noxious weeds, determine how to change management after selecting a treatment method.

B. Livestock manipulation

1. Determine whether changes in livestock grazing will affect the target weeds. 
a. Reduced grazing may allow for increased competition from beneficial vegetation or just allow for more seeds to be disseminated.

b. Increased grazing may reduce beneficial vegetation or may be used to reduce seed source.

2. Determine changes in movement or type of livestock to reduce or contain the infestation due to movement of seeds on or in the animals.

3. Determine whether containing livestock in a weedfree area prior to introduction to the area would prevent new infestations.

C. Wildlife manipulation

1. Determine whether wildlife or wildlife feeding programs can be managed to reduce weed infestations.

2. Determine feasibility of changes in wildlife movement that would reduce or contain the infestation due to movement of seeds on or in the animals.

D. Soil Disturbance Activities

1. Revegetate all bare soil following disturbance.

2. Select plants species that will reduce the spread of noxious weeds.

3. Defer soil disturbance if possible until weeds are controlled or under management.

E. Public use

1. Determine most feasible land use to reduce and prevent infestations.

2. Determine whether specific public awareness programs could reduce the infestation or control the spread of weeds.

3. Determine whether exclusion is a possibility and how it would affect the weed infestation.

II. Physical control A. Manual control

1. Determine whether hoeing or "grubbing" will reduce (or increase) the infestation.

2. Determine whether hand pulling the weeds reduces the seed source.

B. Mechanical control

1. Evaluate terrain to allow for mowing and determine whether it is an acceptable option for control of the spread of seeds. 


\section{Section VII}

\section{Biological control}

\section{Remember, it is the use of all}

the available options in combination that results in the most successful integrated weed management. Support of IWM techniques should not be used as an excuse to exclude one management option over another.
2. Evaluate cultivation and other conventional farm. ing practices options that could be utilized cost effectively.

C. Control by burning

1. Determine whether policy and laws allow controlled burning and address regulations regarding smoke management.

2. Determine whether the terrain and vegetative cover allow for a controlled burn program.

3. Evaluate a controlled burn program to reduce the infestation.

4. Determine long-term effect of burning on nontarget species.

A. Natural competition

1. Determine whether there are naturally occurring agents within the ecosystem which can reduce the infestation.

2. Determine which elements affect naturally occurring control agents.
a. Determine whether these elements can be modified to reduce the negative effect on these agents.
b. Determine whether these elements can be enhanced to increase the effectiveness of these agents on the weed infestation.

B. Introduced competition

1. Determine whether biological control agents can be introduced into the ecosystem to reduce the amount of infestation.

2. Determine which introduced biological agents provide an acceptable control method for this infestation.

3. Evaluate if the biological control agent has been tested for adverse effects against all non-target species within the treatment area.

4. Determine whether the introduced biological agent can survive in the environment of the treatment area.

5. Determine whether policy and laws allow for the introduction of biological control agents.

6. Determine whether policy and laws allow for introduction and grazing of livestock as a biological control measure. 


\section{Section VII}

\section{Chemical control A. Fertilization}

1. Determine whether chemical fertilization would reduce the amount of weeds by increasing competition of beneficial plant species.

2. Determine whether increased nitrogen (or other nutrients) would reduce weeds due to direct effect (e.g., Curlycup gumweed).

B. Pesticides

1. Evaluate the acceptability of herbicides (or other pesticides) to control the infestation.

2. Determine whether pesticides are labeled for:

a. Use on the target weed

b. Use on the infested site (consider nontarget plants, soil type, groundwater location, topography, climate, state labeling, etc.)

c. Determine the most effective application techniques.

3. Determine the most effective and cost-efficient types of conventional application equipment.

4. Determine whether properly trained personnel are available to apply the pesticides.

\section{Notes:}




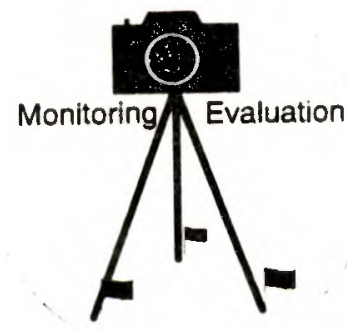

1. Monitoring

\section{Section VIII}

\section{Monitoring and Evaluation}

In many ways, monitoring and evaluation are among the most important parts of a weed program, but by themselves do not kill or prevent weeds.

Because monitoring and evaluation are non-controversial, there may be a temptation to substitute the monitoring and evaluation program for an effective weed management program.

Monitoring and evaluation are "determining the truth" about the program. It is critical not to manipulate data either to make the problem look worse to secure funding, or to minimize the problem in order to demonstrate progress or avoid action.

Monitoring and evaluation are not an external observation of the weed management program, but are as vital to the program as the actual spraying, biological release, or quarantine. They tell the condition of the area we manage and report changes in the condition, so that we can understand the forces driving the changes. Weed-free areas probably deserve more rigorous monitoring and evaluation than known infestations.

Monitoring and evaluation are useful to protect the WMA cooperators from liability for damage caused by others, or that caused in the past. It is important to be able to sort out changes in weeds caused by our weed management activities from those caused by external factors like weather. If treatment can be considered the heart of a program, then monitoring is the eyes and evaluation is the mind.

\section{Monitoring means repeated systematic observation.}

Monitoring begins with the pooling of available information (an inventory of known facts) to establish a point of departure for required monitoring activities. Then target specific information gaps. Assemble the baseline data already possessed by the members of the WMA or other agencies.

A. The purpose of a monitoring system is to:

1. Collect baseline field data on existing weed control practices.

2. Compile data on which to base weed control decisions. 
3. Evaluate effectiveness of treatments including modifications to the design or maintenance of the system and the education and training program.

4. Prevent restarts by returning to eradicated stands to determine if new starts have occurred over a period of time.

B. Different Levels of Monitoring: The following monitoring levels are dependent on the resources and manpower available. Level I requires fewer resources and less time than Level III. Specific areas of each Weed Management Area may require different levels of monitoring. It is almost impossible to fully monitor all areas and/or species; thus, prioritize what you monitor.

\section{Level I}

Objective: To detect new infestations and to assess the success of incidental or small-scale chemical or mechanical control programs.

a. Annually survey size and density of infestations and trend.

b. Assess public opinion towards weeds and weed control.

c. Assemble data on past and current weed control activities within the WMA.

d. Annually update the distribution/density map discussed in Section V, "Inventory."

e. Annually examine areas that are determined to be particularly susceptible to weed infestation.

\section{Level II}

Objective: Assess success of ongoing chemical, biological control, or prevention program in order to evaluate need for adjustments. Includes the elements of Level I plus:
a. Permanent transects to aid all visual monitoring (See Appendix 8).
b. Photo points. Catalog and store photos so that they are useful for recording trends (See Appendix 8).
c. Weather. Requires access to weather records and Palmer Drouth Index.
d. Success of public education program.
e. Monitors funding from various sources. 
f. Assess prevention effort.

g. Compare success of your timing and treatments with that of people in the neighborhood with similar problems.

h. Annual visual inspection for symptoms of damage to desirable plants.

i. Post-treatment inspection to determine need for retreatment and damage.

\section{Level III}

Objective: Assess success of major, sensitive, or experimental control programs. Includes the elements of Levels I and II, plus:

a. Monitor newspapers, turnouts, and opinions at public meetings. Possibly establish an opinion poll.

b. This level may require the use of aerial photos and statistical analysis and chemical analysis.

c. Computerized database. Geological Information Systems ( $\mathrm{ClS}$ ) lend themselves to this level of monitoring.

d. Automatic weather stations may be used. Fully investigate history of land use and weed infestations.

e. Requires specialized maps.

f. Groundwater analysis.

g. Soil analysis.

h. Health effects.

i. Impacts on wildlife.

j. Requires crews dedicated to weed management.

\section{Evaluation}

\section{Evaluation is relating information obtained} trom nomitoring to a goal

A. The purpose of evaluation is to answer those questions:

1. Does my weed management program come as close to accomplishing my goal as is possible with the resources at hand?

2. Is my goal still desirable and realistic? For evaluation to be effective it is necessary to have a goal or standard as a datum to compare the effect of treatments or non-treatments. Evalu- 
ation requires analyzing information gained through monitoring into consideration of benefits versus costs and comparing it with the cost/ benefit of other alternatives. It includes comparing treated with untreated areas. It includes the projected costs of no action.

B. To evaluate and improve the program, the following questions should be answered at the end of the season or between treatments:

1. Was the weed population adequately suppressed?

2. Was the planned procedure used? If not, what was different?

3. Was the cost of suppression equal to or less than the expected damage?

4. If the weed is a native plant or a plant that is valuable under some circumstances, should an alternative use of the land be considered?

5. What damage was produced? What damage was tolerable?

6. Were natural enemies affected by the treatment?

7. Was desirable vegetation affected by the treatment? Positively or negatively?

8. Were there any other side effects from the treatment?

9. Were the side effects included in the cost benefit analysis?

10. If ineffective, should the treatment be repeated?

11. If ineffective, should another kind of treatment be evaluated?

12. What are the new developments in weed control?

13. Did the specific control actions take manpower away from other projects where it might have been more effective?

14. Were money and manpower available at the appropriate time?

15. Was training adequate?

16. Were changes in the weed regime due to external factors? 


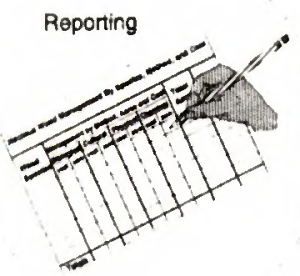

\section{Section IX}

\section{Reporting}

The administration of a noxious weed program includes all activities from inventorying infestations, establishing a Noxious Weed Management Area, developing a plan and applying the management practices to prevent the spread of noxious weeds.

Documentation of a noxious weed program should:

1. Provide an inventory by levels of infestation by species.

2. Be consistent in data collection to allow land managers' reports to be easily aggregated to the GYA level.

3. Track the number of Noxious Weed Management Plans and the number of acres managed by species, by treatment method, and by funding.

Land Management cooperators within the GYA will report the following information. The rationale for selecting these particular items to represent the noxious weed management job is presented after the descriptions of the measures. Each Weed Management Area will report the following information by February 1 of each year to:

Greater Yellowstone Area Team Leader Office

Box 2556

Billings, Montana 59103 (406) 657.6361

\section{Reter 10 Appendlit 7 for s ample forms for the following reportst}

Report \#1 -- Weed Management Area Status Report This annual report charts the progress made in an individual Weed Management Area (WMA) towards organization and completion of the WMA's objectives. This report also records funding required to complete all WMA Management Plan objectives successively. (Use Report Form \#1 found in Appendix 7 )

\section{Report \#2 -- Noxious Weed Management by Species, Method, and Funding}

This annual report represents the total number of acres of noxious weeds placed under management within Weed Management Areas. The treatment technique will differ by site and species. The measurementhere is of acres treated or retreated by 


\section{Section IX}

whatever technique is deemed appropriate in the Weed Management Area Plan. (Use Reporting Form $\# 2$ found in Appendix 7 )

\section{Report \#3 -. Noxious Weed-Infested Acres By} Level By Ownership

This report, filed at 3-year Intervals (beginning in 1991) represents the acres of noxious weed infestations within the Weed Management Area by land ownership (agency, state, private land). Provides a small-scale map of the Weed Management Area with the noxious weed infestations illustrated by species, infestation level, and with land ownership defined. (Use Report form \#3 found in Appendix 7

Infestation levels are:

Low: $\quad$ Occasional plant per acre, less than 5 percent canopy cover

MODERATE: Widely scattered plants, 5-25 percent canopy cover

HICH: $\quad$ More dense, 25-100 percent canopy cover

II. Discussion Noxiousweeds infest all types of lands and impact the quality and quantity of all renewable resources. Coordinated Noxious Weed Management within logical established areas provides the best strategy to achieve management objectives and fully incorporate integrated pest management principles.

Reporting weed infestations by species and infestation level on a 3-year basis will provide information needed to document the trends in noxious weed infestations, their economic impact, and long-term assessment of treatment needs. Reporting the number of Plans and Acres placed under management will provide annual accomplishments, strengthen cooperative actions, and improve the efficiency and effectiveness of noxious weed management in the GYA. 


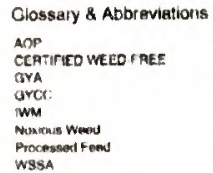

I. Glossary and Definitions

\section{Section $X$ \\ Glossary and Abbreviations}

Annual Operating Plan - A written document which describes in detail the methods, funding, and participants involved in a weed management area. It addresses, on an annual basis, how the objectives of the overall Management Plan are implemented.

Biological Agent - Managed living agents that can decrease the number of noxious weeds by reducing the available nutrients, modifying the plant, or feeding on the plant.

Blological Control Acre - Acre of weed-infested land that has an established biocontrol agent. Established means that a biological agent can be found and is actively reproducing.

Certifled Seed - Seed which meets the standards of a state seed certification program.

Certifled Weed-Free - Having met the GYA or a state weedfree certification standard.

Crop - Agronomic or farm product to be used as feed for livestock or wildlife, bedding, mulches, re-seeding, etc.

Cultural Control - Manipulation of the environment or plant community to reduce weed infestations. Using management techniques other than pesticides, biological control agents, or physical control practices to reduce the amount of noxious weed infestations.

Eariy Detection - Identifying and documenting newly introduced weed species in an area.

Eradication - Employing appropriate management methods to totally remove a weed species in an area, including the weed's reproductive potential.

Exotic Plant - A plant that is not a regular member of the native or natural community in which it is found.

Infested acres - An area of land containing a target weed specie or species. An infested acre of land is mapped by drawing a line around the extremities of the infestation, excluding large areas not infested. Consider only the area canopied by weeds as being infested. Acres containing only occasional weed plants per acre will be based on each weed plant equaling 1 square rod (16 
sq. $\mathrm{ft}$.) or $1 / 160$ th of an acre. Thus, 160 scattered plants equals one acre. Use this measurement because most perennial species are best managed if an area larger than that actually occupied by the weed plant canopy is considered.

Integrated Weed Management - A management system that uses all suitable methods in a compatible manner to reduce weed populations to levels below those causing acceptable economic or ecological consequences.

Managed Acre - A minimum of one acre of infested land where a weed has been treated or retreated by an acceptable method (chemical, biological, mechanical) for the specific objective of controlling its spread and/or reducing its density. An infested area of land would be mapped by drawing a line around the extremities of the infestation, excluding large areas not infested. If this area were treated, the total mapped unit would be counted as treated regardless of the density of the infestation.

Management Plan - A document justifying the necessity of a weed management area. The Management Plan is considered the overall, long-term plan for the WMA. Ideally, its objectives address weed management for at least five years or longer. The management plan shall be accompanied by an Annual Operating Plan.

Material Safety Data Sheets (MSDS) - Documents provided by the chemical manufacturer containing safety information as required by OSHA (Occupational Safety and Health Administration).

Natural Competition (As related to an IWM program) - Native, living agents that can decrease the number of weeds by reducing the available nutrients, modifying the plant, or feeding on the plant.

Noxious Weeds - Noxious weeds are those plant species designated as such by federal or state law. Noxious weeds generally will possess one or more of the characteristics of being aggressive and difficult to manage, parasitic, a carrier or host of serious insects or disease, and being non-native, new to, or not common to the United States.

Physical Control (As related to an IWM program) - The use of either hand labor, mechanical equipment, and/or hurning in control weeds. 
Prevention - Activity (inspection, regulation, sanitation, education) which will reduce the possibility of the introduction of target weeds into a weed management area.

Processed Feed - Any treatment or manipulation that destroys weed seed viability in the finished product. Mechanical processing (cubing, compressing) does not qualify as processed feed.

Steering Committee - A group of individuals appointed or elected to complete a management plan and action plan for a specific weed management area.

Threatened and Endangered Species - Plant species as defined in the Endangered Species Act.

Undesirable Plant Species - Plant species that are of little economic, aesthetic or nutritional value; or are classified as exotic or noxious plants under state or federal law.

Weed Management Area - An area of common characteristics and specific boundaries within the Greater Yellowstone Area which has been designated a logical area for the management of noxious weeds. The area can be based on criteria other than existing jurisdictional boundaries.

\section{Abbreviations}

AOP
BCA
BLM
CFWMA
EA
EIS
GTNP
GYA
GYCC
I\&E
IWM
MP
MSDA
NEPA
OSHA
PAR
PCWPCD
PUP
T\&E
USFS

Annual Operating Plan

Biological Control Agent

Bureau of Land Management

Clarks Fork Weed Management Area

Environmental Analysis

Environmental Impact Statement

Grand Teton National Park

Greater Yellowstone Area

Greater Yellowstone Coordinating Committee

Information \& Education

Integrated Weed Management

Management Plan

Material Safety Data Sheets

National Environmental Policy Act

Occupational Safety and Health Administration

Pesticide Application Record

Park County Weed and Pest Control District

Pesticide Use Proposal

Threatened and Endangered

United States Forest Service 


\section{Section X}
WMA
Weed Management Area
WSSA
Weed Science Society of America
YNP
Yellowstone National Park

\section{Notes:}




\title{
Appendix 1
}

\author{
MEMORANDUM OF UNDERSTANDING \\ between the \\ Governor, State of Wyoming \\ and \\ Governor, State of Montana \\ and \\ Governor, State of Idaho \\ and \\ The Regional Foresters \\ Northern, Rocky Mountain and Intermountain Regions \\ Forest Service \\ and \\ The Parks Director, Rocky Mountain Region \\ National Park Service \\ and \\ The State Directors \\ Montana, Hyoming and. Idaho \\ Bureau of Land Management
}

\section{PURPOSE:}

The purpose of this Memorandum of Understanding (MOU), is to encourage and formalize the coperative relationship necessary for effective management, coordination and implementation of Noxious Weed programs among Forest Service; States of Wyoming, Montana, Idaho; National Park Service and Bureau of Land Management within the Greater Yellowstone Area (GYA). It. continues coordination efforts between the agencies that began in the 1960's when National Forest \& Park managers in the GYA formed the Greater Yellowstone Coordinating Committee.

The objective for the GYA is a coordinated, cohesive \& effective Integrated Pest Management program for Noxious Weeds.

THE UNDERS IGNEI) PARTIES MUTUNLLY AGREE TO:

1. Participate in the Noxious Weed Technical Guidance Group created for the GYA.

2. Utilize the Noxlous Weed Program Guidelines prepared by the technical group to foster coordination, cooperation, and implementation on:

Goals and Objectives

Fieid Training (Education)

action Plans and Implementation

Monitoring

Program Assessments

Aoplying Eradication and/or Control Treatments 


\section{Appendix 2}

\section{Weeds Listed as Noxious or Exotic by Agencies and Jurisdictions within the GYA}

\section{Definitions and Classifications}

\section{Idaho Weed Classification}

Noxious -. Weeds so designated by current laws.

Counties may add additional weeds to the local noxious weed list.

\section{Montana Weed Classification}

Category 1 -- Weeds currently found in Montana at some level of infestation; containment and reduction is a management goal.

Category II - - Weeds currently found in Montana in limited infestations; eradication is a management goal.

Counties may add additional weeds to the local noxious weed list.

\section{Wyoming Weed Classification}

Designated -- The weeds, seeds, or other plant parts that are considered detrimental, destructive, injurious or poisonous, either by virtue of their direct effect or as carriers of disease or parasites that exist within this state, and are on the designated list.

Declared -. $\quad$ Any plant which the board and the Wyoming weed and pest council have found, either by virtue of its direct effect or as a carrier of diseases or parasites to be detrimental to the general welfare of persons residing within a district.

\section{Grand Teton National Park (GTNP) Weed Classification}

Category 1 -- Aggressive invaders that once established are capable of expanding into surrounding areas. Most of these species are designated as noxious weeds by Wyoming law. The primary concern is to stop the spread of these species through control efforts. Hand pulling and herbicide treatments are used with a high degree of success throughout most of the park.

Category 2 -. Invaders that have not been thoroughly researched for correct category designation. Many are thought to be weakly adapted species, spreading slowly into surrounding areas. Some are considered noxious by Wyoming law. The park concern is aimed at documenting their distribution and determining their threat to native vegetation. Control efforts are undertaken to eradicate isolated populations where the possibility of success is high.

Category 3 -- These species have invaded the park and would require intensive control efforts well beyond the current staffing and funding capabilities for eradication. Control efforts are 


\section{Appendix 2}

undertaken to eradicate small, isolated populations where the possibility of success is considered very good.

\section{Yellowstone National Park (YNP) Weed Classification}

Priority 1 .- Aggressive species, likely listed as noxious in surrounding states, now confined to relatively small areas of the park. Control efforts have a high probability of successfully eliminating or preventing spread of the exotic, and will be undertaken.

Priority 11 -- Less aggressive species, likely not noxious but still of concern to the park, found in localized pockets around the park. Control efforts have a fairly high probability of success and will be undertaken as budget and staffing allow.

Priority III -- Aggressive exotics, possibly noxious, which are dispersed over large areas of Yellowstone. Control efforts are likely to be ineffective, costly, and may have deleterious effects on the park ecosystem. Mapping and monitoring may occur as staff time allows. Efforts may be made to control their spread into new locations in the park.

\section{Weed Classifications by Species in the GYA}

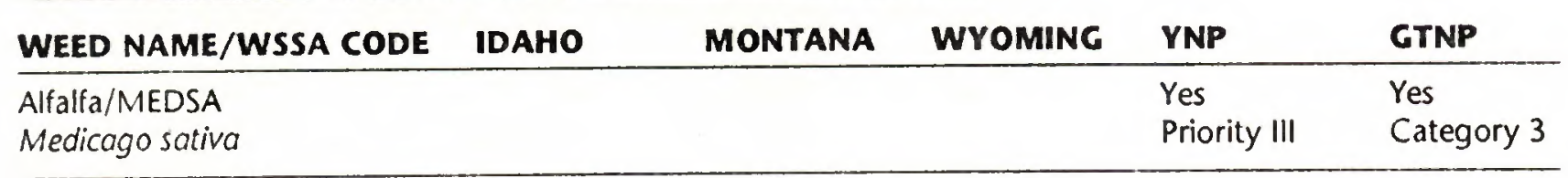

\begin{tabular}{|c|c|c|c|c|c|}
\hline $\begin{array}{l}\text { Austrian field cress/RORAU } \\
\text { Rorippa austriaca }\end{array}$ & $\begin{array}{l}\text { Yes } \\
\text { Noxious }\end{array}$ & & & & \\
\hline $\begin{array}{l}\text { Austrian pea weed/SWASA } \\
\text { Swiansona salsula }\end{array}$ & $\begin{array}{l}\text { Yes } \\
\text { Noxious }\end{array}$ & & & & \\
\hline $\begin{array}{l}\text { Buffalo bur/SOLCU } \\
\text { Solanum rostratum }\end{array}$ & $\begin{array}{l}\text { Yes } \\
\text { Noxious }\end{array}$ & & & & \\
\hline $\begin{array}{l}\text { Camelthorn/ALHPS } \\
\text { Alhagi camelorum }\end{array}$ & $\begin{array}{l}\text { Yes } \\
\text { Noxious }\end{array}$ & & & & \\
\hline $\begin{array}{l}\text { Canada thistle/CIRAR } \\
\text { Cirsium arvense }\end{array}$ & $\begin{array}{l}\text { Yes } \\
\text { Noxious }\end{array}$ & $\begin{array}{l}\text { Yes } \\
\text { Category } 1\end{array}$ & $\begin{array}{l}\text { Yes } \\
\text { Designated }\end{array}$ & $\begin{array}{l}\text { Yes } \\
\text { Priority III }\end{array}$ & $\begin{array}{l}\text { Yes } \\
\text { Category } 3\end{array}$ \\
\hline $\begin{array}{l}\text { Common burdock/ARFMI } \\
\text { Arctium minus }\end{array}$ & & & $\begin{array}{l}\text { Yes } \\
\text { Designated }\end{array}$ & & \\
\hline $\begin{array}{l}\text { Common crupina/CINVU } \\
\text { Crupina velgaris }\end{array}$ & $\begin{array}{l}\text { Yes } \\
\text { Noxious }\end{array}$ & $\begin{array}{l}\text { Yes } \\
\text { Category II }\end{array}$ & & & \\
\hline $\begin{array}{l}\text { Daimatian toadflax/LINDA } \\
\text { Linaria daimatica }\end{array}$ & $\begin{array}{l}\text { Yes } \\
\text { Noxious }\end{array}$ & $\begin{array}{l}\text { Yes } \\
\text { Category I }\end{array}$ & $\begin{array}{l}\text { Yes } \\
\text { Designated }\end{array}$ & $\begin{array}{l}\text { Yes } \\
\text { Priority III }\end{array}$ & $\begin{array}{l}\text { Yes } \\
\text { Category } 3\end{array}$ \\
\hline
\end{tabular}




\section{Appendix 2}

\begin{tabular}{|c|c|c|c|c|c|}
\hline WEED NAME/WSSA CODE & IDAHO & MONTANA & WYOMING & YNP & GTNP \\
\hline $\begin{array}{l}\text { Downy brome/BROTE } \\
\text { Bromus tectorum }\end{array}$ & & & & $\begin{array}{l}\text { Yes } \\
\text { Priority III }\end{array}$ & $\begin{array}{l}\text { Yes - Not } \\
\text { Classified }\end{array}$ \\
\hline $\begin{array}{l}\text { Diffuse knapweed/CENDI } \\
\text { Centaurea diffusa }\end{array}$ & $\begin{array}{l}\text { Yes } \\
\text { Noxious }\end{array}$ & $\begin{array}{l}\text { Yes } \\
\text { Category I }\end{array}$ & $\begin{array}{l}\text { Yes } \\
\text { Designated }\end{array}$ & & $\begin{array}{l}\text { Yes } \\
\text { Category } 1\end{array}$ \\
\hline $\begin{array}{l}\text { Dyers woad/ISATI } \\
\text { Isatis tinctoria }\end{array}$ & $\begin{array}{l}\text { Yes } \\
\text { Noxious }\end{array}$ & $\begin{array}{l}\text { Yes } \\
\text { Category } 11\end{array}$ & $\begin{array}{l}\text { Yes } \\
\text { Designated }\end{array}$ & & $\begin{array}{l}\text { Yes } \\
\text { Category } 2\end{array}$ \\
\hline $\begin{array}{l}\text { Field bindweed/CONAR } \\
\text { convolvulus arvensis }\end{array}$ & $\begin{array}{l}\text { Yes } \\
\text { Noxious }\end{array}$ & $\begin{array}{l}\text { Yes } \\
\text { Category I }\end{array}$ & $\begin{array}{l}\text { Yes } \\
\text { Designated }\end{array}$ & $\begin{array}{l}\text { Yes } \\
\text { Priority } 1\end{array}$ & $\begin{array}{l}\text { Yes } \\
\text { Category } 2\end{array}$ \\
\hline $\begin{array}{l}\text { Goatweed (St. Johnswort)/HYPPE } \\
\text { Hypericum perforatum }\end{array}$ & & $\begin{array}{l}\text { Yes } \\
\text { Category } 1\end{array}$ & & $\begin{array}{l}\text { Yes } \\
\text { Priority } \|\end{array}$ & \\
\hline $\begin{array}{l}\text { Globepodded hoarycress/CADP } \\
\text { Cardaeria pubescens }\end{array}$ & & & & $\begin{array}{l}\text { Yes } \\
\text { Priority III }\end{array}$ & \\
\hline
\end{tabular}

\begin{tabular}{|c|c|c|c|c|c|}
\hline $\begin{array}{l}\text { Henbane/HSYNI } \\
\text { Hyoscyamus niger }\end{array}$ & $\begin{array}{l}\text { Yes } \\
\text { Noxious }\end{array}$ & & & & $\begin{array}{l}\text { Yes } \\
\text { Category } 2\end{array}$ \\
\hline $\begin{array}{l}\text { Hoary cress (Whitetop)/CADDR } \\
\text { Cardaria draba }\end{array}$ & $\begin{array}{l}\text { Yes } \\
\text { Noxious }\end{array}$ & $\begin{array}{l}\text { Yes } \\
\text { Category } 1\end{array}$ & $\begin{array}{l}\text { Yes } \\
\text { Designated }\end{array}$ & $\begin{array}{l}\text { Yes } \\
\text { Priority } \|\end{array}$ & \\
\hline $\begin{array}{l}\text { Houndstongue/CYWOF } \\
\text { Cynoglossum officialnale }\end{array}$ & & & $\begin{array}{l}\text { Yes } \\
\text { Designated }\end{array}$ & $\begin{array}{l}\text { Yes } \\
\text { Priority } 1\end{array}$ & $\begin{array}{l}\text { Yes } \\
\text { Category } 2\end{array}$ \\
\hline
\end{tabular}

\begin{tabular}{|c|c|c|c|c|c|}
\hline $\begin{array}{l}\text { Jointed goatgrass/AECCY } \\
\text { Aegilops cylindrica }\end{array}$ & $\begin{array}{l}\text { Yes } \\
\text { Noxious }\end{array}$ & & & & \\
\hline $\begin{array}{l}\text { Leafy spurge/EPHES } \\
\text { Euphorbia esula }\end{array}$ & $\begin{array}{l}\text { Yes } \\
\text { Noxious }\end{array}$ & $\begin{array}{l}\text { Yes } \\
\text { Category I }\end{array}$ & $\begin{array}{l}\text { Yes } \\
\text { Designated }\end{array}$ & $\begin{array}{l}\text { Yes } \\
\text { Priority } 1\end{array}$ & $\begin{array}{l}\text { Yes } \\
\text { Category } 2\end{array}$ \\
\hline $\begin{array}{l}\text { Loosestrife/LYTSA } \\
\text { Lythrum salicaria }\end{array}$ & $\begin{array}{l}\text { Yes } \\
\text { Noxious }\end{array}$ & & & & \\
\hline $\begin{array}{l}\text { Musk thistle/CRUNU } \\
\text { Carduus nutons }\end{array}$ & $\begin{array}{l}\text { Yes } \\
\text { Noxious }\end{array}$ & & $\begin{array}{l}\text { Yes } \\
\text { Designated }\end{array}$ & $\begin{array}{l}\text { Yes } \\
\text { Priority } 1\end{array}$ & $\begin{array}{l}\text { Yes } \\
\text { Category } 1\end{array}$ \\
\hline $\begin{array}{l}\text { OX-eye daisy/CHYLE } \\
\text { Chrysanthemum leucanthemum }\end{array}$ & & & $\begin{array}{l}\text { Yes } \\
\text { Designated }\end{array}$ & $\begin{array}{l}\text { Yes } \\
\text { Priority } 1\end{array}$ & \\
\hline $\begin{array}{l}\text { Perennial pepperweed/LEPLA } \\
\text { Lepidium latifollium }\end{array}$ & $\begin{array}{l}\text { Yes } \\
\text { Noxious }\end{array}$ & & $\begin{array}{l}\text { Yes } \\
\text { Designated }\end{array}$ & & $\begin{array}{l}\text { Yes } \\
\text { Category } 2\end{array}$ \\
\hline $\begin{array}{l}\text { Perennial sowthistle/SONAR } \\
\text { Sonchus arvensis }\end{array}$ & $\begin{array}{l}\text { Yes } \\
\text { Noxious }\end{array}$ & & $\begin{array}{l}\text { Yes } \\
\text { Designated }\end{array}$ & & \\
\hline $\begin{array}{l}\text { Plumeless thistle/CRUAC } \\
\text { Cardius acanthoides }\end{array}$ & & & $\begin{array}{l}\text { Yes } \\
\text { Designated }\end{array}$ & & \\
\hline
\end{tabular}




\section{Appendix 2}

\begin{tabular}{|c|c|c|c|c|c|}
\hline WEED NAME/WSSA CODE & IDAHO & MONTANA & WYOMING & YNP & GTNP \\
\hline $\begin{array}{l}\text { Poison hemlock/COIMA } \\
\text { Conium maculatum }\end{array}$ & $\begin{array}{l}\text { Yes } \\
\text { Noxious }\end{array}$ & & & & $\begin{array}{l}\text { Yes - Not } \\
\text { Classified }\end{array}$ \\
\hline $\begin{array}{l}\text { Puncture vine/TRBTE } \\
\text { Tribulus terrestris }\end{array}$ & $\begin{array}{l}\text { Yes } \\
\text { Noxious }\end{array}$ & & & & \\
\hline $\begin{array}{l}\text { Quackgrass/AGRRE } \\
\text { Agropyron repens }\end{array}$ & & & $\begin{array}{l}\text { Yes } \\
\text { Designated }\end{array}$ & $\begin{array}{l}\text { Yes } \\
\text { Priority III }\end{array}$ & $\begin{array}{l}\text { Yes - Not } \\
\text { Classified }\end{array}$ \\
\hline $\begin{array}{l}\text { Rush skeletonweed/CHOJU } \\
\text { Chondrilla juncea }\end{array}$ & $\begin{array}{l}\text { Yes } \\
\text { Noxious }\end{array}$ & $\begin{array}{l}\text { Yes } \\
\text { Category II }\end{array}$ & & & $\begin{array}{l}\text { Yes } \\
\text { Category } 2\end{array}$ \\
\hline $\begin{array}{l}\text { Russian knapweed/CENRE } \\
\text { Centaurea repens }\end{array}$ & $\begin{array}{l}\text { Yes } \\
\text { Noxious }\end{array}$ & $\begin{array}{l}\text { Yes } \\
\text { Category I }\end{array}$ & $\begin{array}{l}\text { Yes } \\
\text { Designated }\end{array}$ & $\begin{array}{l}\text { Yes } \\
\text { Priority I }\end{array}$ & $\begin{array}{l}\text { Yes } \\
\text { Category } 2\end{array}$ \\
\hline $\begin{array}{l}\text { Scotch thistle/ONRAC } \\
\text { Onopordun acanthium }\end{array}$ & $\begin{array}{l}\text { Yes } \\
\text { Noxious }\end{array}$ & & $\begin{array}{l}\text { Yes } \\
\text { Designated }\end{array}$ & & \\
\hline
\end{tabular}

Silver-leaf nightshade/SOLEL Yes

Solanum elaeagnifolium

Noxious

Skeletonleaf bursage/FRSTO Y

Ambrosia tomentosa

Yes Yes

Noxious Designated

\begin{tabular}{|c|c|c|c|c|c|}
\hline $\begin{array}{l}\text { Smooth brome/BROIN } \\
\text { Bromus inermis }\end{array}$ & & & & $\begin{array}{l}\text { Yes } \\
\text { Priority III }\end{array}$ & $\begin{array}{l}\text { Yes - Not } \\
\text { Classified }\end{array}$ \\
\hline $\begin{array}{l}\text { Spotted knapweed/CENMA } \\
\text { Centaurea maculosa }\end{array}$ & $\begin{array}{l}\text { Yes } \\
\text { Noxious }\end{array}$ & $\begin{array}{l}\text { Yes } \\
\text { Category I }\end{array}$ & $\begin{array}{l}\text { Yes } \\
\text { Designated }\end{array}$ & $\begin{array}{l}\text { Yes } \\
\text { Priority } 1\end{array}$ & $\begin{array}{l}\text { Yes } \\
\text { Category } 1\end{array}$ \\
\hline $\begin{array}{l}\text { Syrian bean caper/ZYGFA } \\
\text { Zygophyllum fabago }\end{array}$ & $\begin{array}{l}\text { Yes } \\
\text { Noxious }\end{array}$ & & & & \\
\hline $\begin{array}{l}\text { Tansy Aster/CHYU } \\
\text { Tanacetum vulgare }\end{array}$ & & & & $\begin{array}{l}\text { Yes } \\
\text { Priority } 1\end{array}$ & $\begin{array}{l}\text { Yes } \\
\text { Category } 1\end{array}$ \\
\hline $\begin{array}{l}\text { Tansy ragwort/SNEJA } \\
\text { Senecio jacobaea }\end{array}$ & $\begin{array}{l}\text { Yes } \\
\text { Noxious }\end{array}$ & & & & \\
\hline $\begin{array}{l}\text { Timothy/PHLPR } \\
\text { Phleum protense }\end{array}$ & & & & $\begin{array}{l}\text { Yes } \\
\text { Priority III }\end{array}$ & $\begin{array}{l}\text { Yes - Not } \\
\text { Classified }\end{array}$ \\
\hline $\begin{array}{l}\text { Wild Carrot/DAUCA } \\
\text { Daucus carota }\end{array}$ & $\begin{array}{l}\text { Yes } \\
\text { Noxious }\end{array}$ & & & & \\
\hline $\begin{array}{l}\text { Woolly (common) mullein/ } \\
\text { Verbascum thapsus }\end{array}$ & & & & $\begin{array}{l}\text { Yes } \\
\text { Priority II }\end{array}$ & $\begin{array}{l}\text { Yes } \\
\text { Category } 1\end{array}$ \\
\hline
\end{tabular}




\section{Appendix 2}

\begin{tabular}{|c|c|c|c|c|c|}
\hline WEED NAME/WSSA CODE & IDAHO & MONTANA & WYOMING & YNP & GTNP \\
\hline Yellow starthistle/CENSO & Yes & Yes & & & \\
\hline Centaurea solstitialis & Noxious & Category II & & & \\
\hline Yellow sweetclover/MEUOF & & & & Yes & Yes \\
\hline Melilotus officinalis & & & & Priority III & Category 2 \\
\hline Yellow toadflax/LINVU & Yes & & Yes & Yes & Yes - Not \\
\hline Linaria vulgaris & Noxious & & Designated & Priority $\|$ & Classified \\
\hline
\end{tabular}

\section{Notes:}




\section{Appendix 3}

\section{Existing Weed Laws, Regulations, and Policies}

National Definition: Integrated Pest Management (IPM) is the consideration, evalu-

Forest ation, and use of alternatives available in resource management to prevent, Service eradicate, or mitigate noxious weeds and their impact.

Management of noxious weeds embodies those activities consistent with noxious weed objectives. Management activities may include education and efforts to prevent, eradicate, reduce, confine, or control noxious weeds through mechanical, biological, chemical, or cultural treatments, or other measures as appropriate.

Noxious weeds are those plant species designated as such by the Secretary of Agriculture, Secretary of Interior, or by state law or regulation. Generally, noxious weeds will possess one or more of the characteristics of being non-native, aggressive and difficult to manage, parasitic, or a carrier or host of serious insects or disease.

The objectives of the National Forest Service for noxious weed management include:

1. Implement an integrated pest management approach in management of noxious weeds through cooperation, coordination, and communication among federal, state, and local agencies, organizations, and individuals.

2. Provide, promote, and facilitate continuing research and technology developments for implementing integrated pest management approaches for managing noxious weeds.

3. Cooperate with other land management agencies in developing mutually compatible noxious weed management policies.

4. Provide leadership for partnerships with state and local weed control organizations.

5. Increase the general level of knowledge, awareness, and commitment to noxious weed management.

6. Consider the non-harmful, beneficial uses of noxious weeds as part of an IPM approach that will not promote the establishment and spread of noxious weed populations.

The policy of National Forest Service noxious weed management is as follows:

1. All forest land management plans will address noxious weed management through an integrated resource approach.

2. Priority for treatment of noxious weeds shall be the prevention of establishment of potential invaders first, control of new and invading species second, followed by management efforts on established stands.

3. Treatment efforts shall be coordinated with cooperators, and be 


\section{Appendix 3}

cost-effective as determined by the potential impact of the possible spread of noxious weeds into new environments. Emphasize preventing establish -ment first, followed by the growth and spread of noxious weeds in all land management projects and activities.

4. The Forest Service shall manage, to the extent practical, noxious weeds on all National Forest System lands. All resources program areas of the National Forest System are responsible for noxious weed management, prevention, and control.

5. Seed planted on National Forest System lands shall be certified and be noxious weed seed-free under the guidelines set in the Secretary of Agriculture's Seed Certification Policy. Coordinate with state certification programs to meet state standards.

6. Encourage cooperative research, development, and application programs that define the ecological requirements of noxious weeds, costeffective management strategies, and beneficial uses.

7. Cooperate with national and international agencies in the research and introduction of biological control agents for noxious weeds.

8. Encourage continuing education of integrated pest management approaches for noxious weeds through state extension services, state universities, and state Departments of Agriculture.

9. Cooperate with other Federal agencies, State, county, and local governments in the redistribution of biological control agents in North America for noxious weeds.

10. Encourage research, development, and the use of desirable plant species in revegetation and fire rehabilitation projects that are competitive with noxious weeds.

11. Emphasize human and environmental safety in carrying out all programs and activities relating to noxious weed control.

12. Assess all proposed control projects to determine the factors which favored the initial establishment and spread of noxious weeds. Design management to correct (where possible) those conditions to reduce the need for future treatment(s).

13. Cooperate in the development of state and federal inter-agency data bases, training, educational materials, and handbooks for management of noxious weeds.

14. Support the USDA National Agricultural Pest Information System by providing National Forest System noxious weed data.

15. Cooperate in the development of an inter-agency system to inventory, monitor, and evaluate the management of noxious weeds.

16. Encourage local regulation for controlling the transport of noxious weed seeds onto National Forest System lands via livestock feeds, logging, contruction, and recreation equipment. 


\section{Appendix 3}

\section{Responsibility:}

The Forest Supervisor:

1. Prepare a noxious weed action plan, tiered to the Forest Plan, that emphasizes integrated management, prevention, and includes inventory, treatment, monitoring, and public awareness and participation programs.

2. Monitor the intensity and extent of noxious weed infestations and provide an estimate on the current and potential impacts to all resources on National Forest System lands.

3. Provide training for the identification of known and potential noxious weeds in and surrounding the Forest.

4. Ensure that environmental concerns, including applicable laws and regulations such as NEPA, NFMA, Clean Water, etc., are followed in all decisions related to the application of herbicides for noxious weed management or control.

Authority:

1. The authority for noxious weed management on National Forest System lands is in 36 CFR 222.8

2. USDA Departmental Regulation Number 9500-10

3. Federal Noxious Weed Act of 1952 [PL 93-629] as amended

4. Carlson-Foley Act of 1968 [PL 90-583]

5. Halogeton Golmeratus Control Act of 1952 [USC 1651-1656]

6. Federal Seed Act of 1939 [7 USC 1551-1611]

7. Federal Plant Pest Act of 1957 [7 USC, Section 150aa-ii]

8. See FSM 2201 for additional legislative authorities.)

Funding: All resource program areas of the National Forest Service are responsible for noxious weed management, prevention, and control. Direct funding for noxious weed treatment programs is within the range management budget.

Bureau of Definition: The Bureau of Land Management (BLM) controls all noxious weed Land infestations through use of an Integrated Pest Management (IPM) program.

Management Given a variety of alternatives for a particular problem, the most cost-effective and environmentally sound method is chosen. In addition to conforming to departmental policy, the BLM must also prepare an environmental analysis for each pest control proposal.

Responsibility: The BLM director formulates noxious weed control policy within the confines of the Department of the Interior policy guidelines. The Forestry staff is responsible for reviewing all pest control programs for compliance with label restrictions where pesticides are the chosen method. Each BLM state director then reviews the pest control programs for his area. The actual planning and implementation of the pest control plans are the duties of each district manager. 


\section{Appendix 3}

The district manager coordinates all plans with appropriate State agencies, other interested agencies, user groups, and the general public.

Funding: Currently, funding for noxious weed control is derived either from the Range Management Division (special appropriations) or from Range Improvement funds, acquired through grazing fees.

National Park Service

Definition: The National Park Service (NPS) utilizes an Integrated Pest Management (IPM) program to deal with alien, exotic or weed plant species. It is the policy of the Department of the Interior and individual parks to use chemical herbicide control only if all other alternatives are unacceptable. Herbicides must be approved in advance by the Regional and Washington offices.

The IPM program includes mapping and identifying sources of infestation. The program evaluates the impact of each specie on the environment, as well as the probable impact of ensuing control actions. Priorities are designated using the system in the NPS Guide to Pesticide Use. Top priority includes exotics that highly affect park resources and have a reasonable chance of succeeding. Control efforts include monitoring traffic and restricting the introduction of additional or new exotic weed seeds through introduced vegetation or forage supplies.

Responsibility: The Resource Management and Visitor Protection Division at Yellowstone and the Science and Natural Resources Division at Grant Teton are primarily responsible for writing and implementing the Resource Management Plan (RMP), of which the IPM is a division. In Yellowstone Park a committee consisting of the Assistant Chief Ranger, a research biologist, the IPM coordinator, and an additional member of the Resource Management staff is responsible for determining and updating park-wide categories (Priority Classifications I-IV for exotic species control) for management action. The assignment of exotic species into categories may change with time, therefore the listing appears in appendices of the Exotic Vegetation Management Plan and may be revised by the Resource Management staff as needed.

The IPM coordinator is responsible for direct supervision of exotic species and hiring seasonal crews for field work. Revisions of the IPM and RMP are also under the coordinator's jurisdiction if deemed necessary.

Funding: The park resources management divisions fund exotic species control efforts. Grand Teton National Park contracts with the Teton County Weed and Pest Control Board for herbicide treatments along with some of the road rights-of-way in the park. Individual parks must make a sincere effort to provide for ongoing, priority control efforts in the annual budget. Otherwise monies may be derived by applying for Natural Resources Preservation Program funds. 


\section{Appendix 3}

MONTANA Organization: Every county in Montana is designated as a weed district area. NOXIOUS County commissioners appoint a weed board to administrate the weed control WEED LAW program. Each weed control district must develop a management plan. The plan includes goals and priorities, distribution and abundance of noxious weed species, and an estimate of personnel cost, operation, and equipment for the program.

Noxious Weed List: The designated noxious weed list is established at the state level and must be followed by all counties. Individual counties also have the option to include additional weeds in their area.

Funding: Funding for weed control is collected at the county level. A county can levy up to a 2 mills to fund the weed district. Funding may also be derived from the general county fund, however that happens infrequently.

A state grant program exists from which counties or groups within a county may solicit funds. The cost-share is funded from a Noxious Weed Trust Fund financed by a $1 \%$ surcharge on all herbicides sold in the state and a $\$ 1.50$ per licensed vehicle surcharge. An advisory council distributes grant money based on individual group requests. Most requests target control of a specific weed. Organizations and groups requesting funds must have been organized for a certain amount of time and the county must have an active weed district.

IDAHO Organization: In Idaho, each county is also a weed district. The county NOXIOUS WEED LAW commissioner is the weed authority and hires a weed superintendent to enforce the program. The law specifies that landowners must control their own weeds and cover the expenses themselves.

A new revision in Idaho's weed law states that all control efforts must be directed at eradication. However, special management zones are set up to designate areas where weed infestations are beyond economically feasible control levels. Special management zones are listed at the state agricultural office and the county weed office. Prospective commodity buyers check the listing to rule out the possibility of noxious weed seed infestation.

Noxious Weed List: The noxious weed list is established at the state level but within the rules and regulations of the state law. Idaho legislators placed the noxious weed list in the rules and regulations so that as weed species were changed, the decision didn't require a vote.

Funding: Funding for weed control is appropriated through a county mill levy up to $6 / 10$ of a mill. The county can increase up to this level. The cost of weed control is the landowner's or land agency's responsibility. Cost-share funds are also available to counties through a legislative appropriation budgeted at approximately $\$ 100,000$ annually. 


\section{Appendix 3}

WYOMING Organization: All land within the state, including federal, state, private, and NOXIOUS municipally-owned lands, are included in a district. Municipalities with a population of 5,000 or greater may establish and administer their own program. If the cities choose not to, the district administers the program. If a city administers its own program they receive $85 \%$ of funds collected within the city and $15 \%$ is retained by the county to provide technical assistance.

County commissions appoint a district board which oversees the district activities. District boards have certain duties and powers issued by state statutes. The district must employ a certified supervisor. Cost-share programs may be established at the discretion of the district board.

Noxious Weed and Pest List: The noxious weed and pest list is designated at the state level between the State Board of Agriculture and the Wyoming Weed and Pest Council. Individual districts may request that a declared weed or pest be added to the list if it poses significant or detrimental threat within the district. The addition only applies to their area.

Funding: Funding for the district program is derived from a one mill levy assessed up on all property within the county. This tax is not part of the general county or city mill levies. Funds collected are used to carry out the act within the district. Special funding may be requested from the state legislature. If a weed or pest is seriously endangering areas of the state, assistance in control may be provided by legislative appropriation for this purpose.

Weed and Pest Special Management Program: An additional one mill may be assessed within the county to implement the special management program. The option to initiate this program is at the discretion of the district board and county commissioners. If the program is implemented the district has to establish management zones, complete an inventory survey, and establish management criteria. Assistance to a district's coordinated program may also be provided by legislative appropriation. 


\section{Appendix 4}

\section{GYA Certification Standards}

Feeds (livestock and wildlife), Mulches, Bedding, and Re-seeding Materials shall be free of noxious weeds as defined in the GYA noxious weed guidelines. Weed species classified as declared, designated, prohibited, restricted, primary, secondary or classified as noxious by other federal or state law shall be considered prohibited and will not be allowed into the GYA.

A. Feeds, Mulches, Bedding, and Re-seeding Materials shall be inspected in the State of Origin by proper officials or authority.

B. Feeds, Mulches, Bedding, and Re-seeding Materials shall also be inspected in the field of origin (field shall include surrounding ditches, fence rows, roads, easement, right-of-way or buffer zone).

C. Field shall be inspected prior to cutting or harvesting.

D. Feeds, Mulches, Bedding, and Re-seeding Materials which contains any noxious weeds or weeds classified as noxious by state or federal law may be certified if the following requirements are met:

1. Field upon which the feeds, mulches, bedding, and re-seeding materials were produced was treated to prevent seed formation or seed ripening to the degree that there is no danger of dissemination of the seed or any injurious portion thereof from such weeds or undesirable plant species.

2. Weed(s) or undesirable plant species was treated no later than bud stage.

3. Propagative parts of the plant are not capable of producing a new plant.

4. Field shall be inspected prior to cutting or harvesting by the proper officials or authority.

E. Certificate shall document that the above requirements have been meet (a..d) based upon a reasonable and prudent visual inspection.

F. Treatment method can include but is not limited to:

1. burning

2. mowing or cutting

3. cultural methods

4. chemicals

G. Interstate and intrastate shipment of feeds, mulches, bedding, and reseeding materials shall be accompanied by a certificate issued by proper officials or authority in the state of origin. Shipments not accompanied by proper certificate may be rejected.

H. Proper officials or authority

1. Representatives of the State's Department of Agriculture

2. Weed Supervisors or Weed Superintendents

3. University Extension Agents

4. An individual designated by that State's Law

5. Authorized individuals from agencies within the GYA. 


\section{Appendix 4}

I. Exemption:

1. Pellets and pelleted milled feeds processed may be exempt based on official testing completed annually by a state or federal seed lab for weed seed viability. Proof of results shall be submitted to GYCC team leader or his designee or accompany the transporter of the crops. Exemption may also be granted providing the following requirements are met:

a. Ditches, fence rows, roads, easements, rights-of-way, or buffer zones surrounding the field of origin is treated to prevent seed formation or seed ripening to the degree that there is no danger of dissemination of the seed or any injurious portion thereof of such weeds or undesirable plant species.

b. Weed $(s)$ or undesirable plant species was treated no later than bud stage.

2. Special exemption to portions of the GYA Certification Standards may be granted by the affected WMA in consultation with the GYA team leader or his designee on a case-by-case basis.

3. Special exemption to portions of the Certification Standards may be granted by the affected agency in consultation with the WMA on a case-by-case basis.

4. Shipment of agronomic crops or farm products through the GYA need not be certified if covered in a prescribed manner as not to allow the dissemination of weeds or undesirable plant species.

J. Proof of Certification shall accompany the shipment of agronomic crops or farm products. The certification certificate shall contain the following:

1. Name of cooperator

2. Description and amount of agronomic crop or farm product

3. Issue date

4. Name, address, title of authorized person issuing certificate

5. Point of origin of feeds, mulches, bedding, and re-seeding materials

K. Using a certificate for feeds, mulches, bedding, and re-seeding materials from other fields or farms than the one specified shall constitute a violation or administrative action or ticketing and charges may be filed with the proper authority or county attorney for prosecution or permit revocation.

DISCLAIMER: Certification standards may not meet the forage quality standards adopted by the Hay Marketing Task Force of the American Forage and Grassland Council. 


\section{Appendix 5}

\section{Guidelines For Public Meetings}

This section offers guidelines and a helpful checklist for conducting a successful public meeting (see meeting materials checklist at end of this section).

\section{Keep It Simple, to the Point, and Brief!}

\section{Keep the Tone of the Meeting Positive at ALL Times!}

I. Determine A. Define the purpose of this meeting and what you hope to accomplish.

Meeting B. Who should be invited?

Objectives

1. Identify and invite local residents known to be interested and active in weed management.

2. Personally contact the key people you want to participate (who can challenge or block a decision?).

3. Make sure key agencies are represented (who can make decisions for the agency?).

4. Make sure the group is broad-based.

5. Keep it local (hold several meetings if necessary to accomplish this).

II. Organize The

A. Type of Meeting - Presentation, feedback, problem-solving, decisionMeeting Well making, combination

B. Define clear desired outcomes

C. Design effective agendas (see worksheet in this section)

1. Determine length of the meeting (keep the meetings short)

2. Identify who will serve as chairperson, meeting manager, facilitator, and recorder.

3. Keep discussion centered on the agenda (form a WMA, determine the best management options, treatment priority, etc.).

D. Stay on time.

E. Form a Board of Directors or Steering Committee to keep project progressing.

1. Choose a broad-based board or committee.

2. Keep board/steering committee to fewer than 10 members.

III. Anticipate A. Flip Charts or overheads

and Provide B. Markers

Meeting C. Maps to identify areas to be discussed

Materials D. Coffee, refreshments (Be sensitive to your audience and the time of the meeting). 


\section{Appendix 5}

IV. Decision-A. Clearly define the decision-making process.

Making Process B. How will decisions be made?

1. Consensus

2. Majority vote

3. One person

C. Who will be the final decision maker?

1. Manager

2. Group

3. Some other manager or group

V. Conduct A. Get everyone involved.

Productive B. Facilitate discussion to keep it on track.

Meetings C. Use a strategy for solving problems and responding to opportunities.

D. Build high quality, consensus decisions.

1. Consensus decisions are built on a series of agreements.

2. Consensus decisions agree with desired outcomes.

VI. Insure cood A. Evaluate the effectiveness of meetings.

Meeting B. Organize the information produced.

Follow-up C. Produce useful minutes.

D. Plan for implementation of decisions and future meetings.

\section{Notes:}




\section{Appendix 5}

\section{Checklist For Setting Up A Public Meeting}

$\square$ Reserve appropriate room and equipment

$\square$ Decide on seating arrangement

$\square \quad$ Design an agenda

$\square$ Send out a memo announcing the meeting and an agenda

$\square \quad$ Make charts and overheads

$\square$ Arrange for refreshments

$\square \quad$ Make sure key influencers received invitations to the meeting

$\square \quad$ Arrive at the meeting room early to double check the room arrangements, verify any audio/visual equipment needed is in proper working condition, and display any charts or brochures

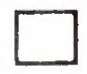

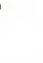




\section{Meeting Preparation Form}

\section{Date}

\section{Action Planning Worksheet for Meeting}

Why:

Why have a meeting? Is there a need? Is there another way to solve the problem?

Who:

Who should attend the meeting? Who has relevant expertise, is concerned, has the power to make the decision, or has the power to challenge or block the decision?

\section{Desired Outcomes:}

What will be the desired outcomes of the meeting?

What will success look like?

Specifically, what should be accomplished?

Type:

What type of meeting will you hold (presentation, feedback, problem-solving, decisionmaking, combination)?

\section{Length:}

What will be the length of the meeting?

\section{Roles:}

What will be the various roles in the meeting? Who will serve in these roles? Will there be a senior manager or chairperson? Will there also be a facilitator? Will there be a recorder and wall minutes (group memory)?

Manager/chairperson:

Facilitator:

Recorder:

\section{Decision-Making Process:}

Who will be the final decision maker? Who will make the final decisions? Who will have the power to decide and how will decisions be made (manager, group, or some other manager or group)? 


\section{Appendix 5}

\section{Public Meeting Agenda}

Group/Meeting Name:

Date:

Time: From

to

Location:

Purpose:

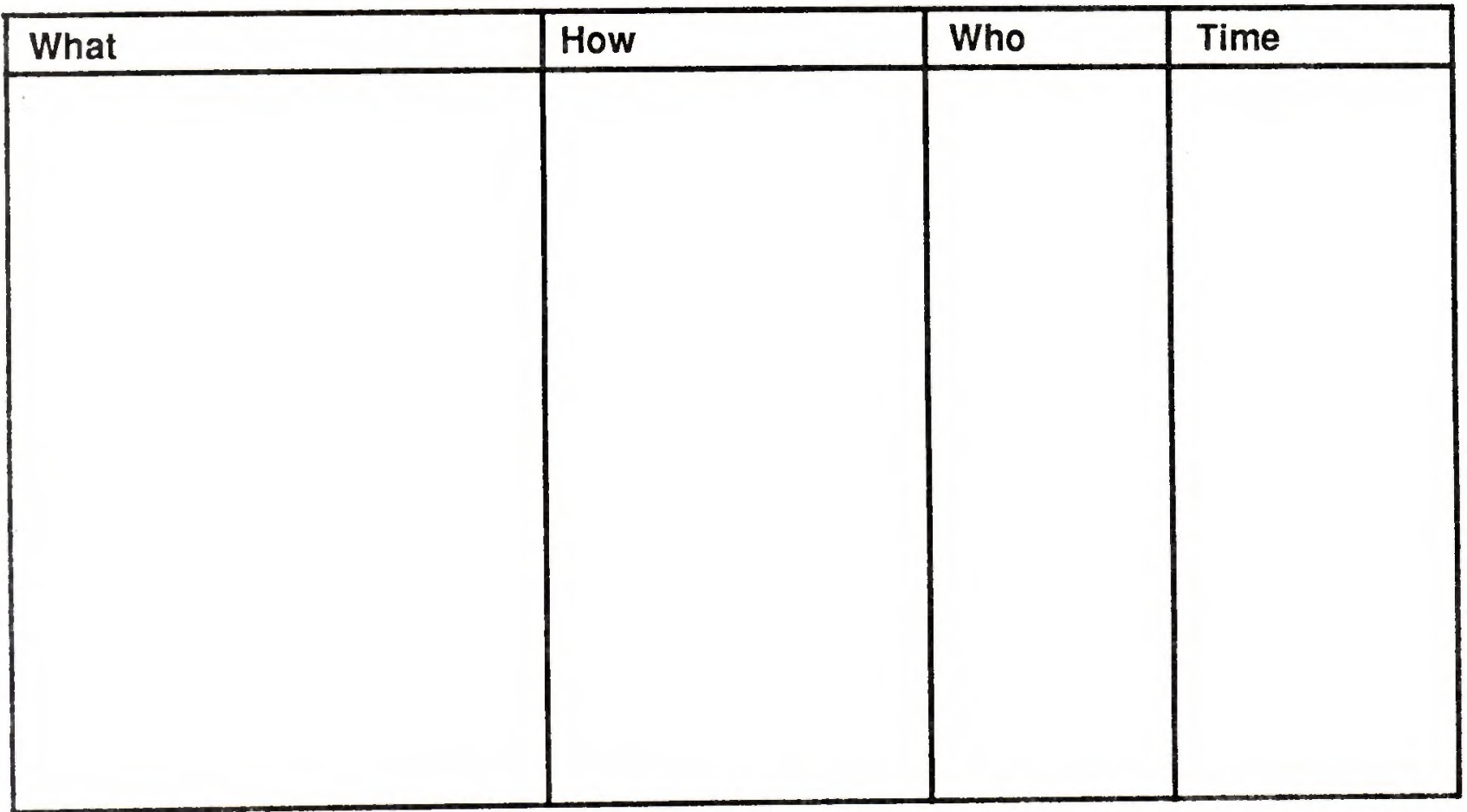




\section{Appendix 6}

\section{Noxious Weed Information Questionnaire}

\begin{tabular}{l} 
PROPERTY NAME \\
OWNER \\
ADDRESS MANAGER \\
TOWN \\
PHONE NO. \\
COUNTY STATE \\
LAND LOCATION \\
\hline
\end{tabular}

1. Total Acres In Unit

\begin{tabular}{|c|c|}
\hline ACRES OWNED & LAND TYPE \\
\hline & Rangeland \\
\hline & Right-of-way \\
\hline & BLM \\
\hline & State \\
\hline & Other \\
\hline
\end{tabular}

ACRES LEASED

Please answer the following questions as completely as possible. This questionnaire is useful if it also reveals what we DON'T KNOW about our Weed Management Area. An accurate picture of our WMA is a valuable tool towards ultimate weed management success.

2. Predominant Weed Species in this unit? Place a check by the ones that you can identify.

ACRES/WEED SPECIES Canada Thistle Dalmatian toadflax Diffuse knapweed Houndstongue Musk thistle Rush Skeletonweed Spotted knapweed Tansy ragwort Yellow starthistle
ACRES/WEED SPECIES Common crupina Dyer's woad Field bindweed Leafy Spurge Perennial sowthistle Russian knapweed St. Johnswort Whitetop Yellow toadflax

3. Are the weeds currently mapped?

Yes No Don't Know 


\section{Appendix 6}

4. Is there an organized Control Program underway?

Yes

No Don't know

5. How many acres treated? Don't Know

6. Specify the predominant application method used on your unit: (mark "yes" by all that apply) Self-applied: $\%$ rope-wick applicator hand sprayer boom/broad jet sprayer biological Don't Know Custom-applied: $\%$ helicopter fixed wing control grazing mechanical

7. Where do you feel the major source of your weeds come from?

Right-of-way
adjoining land
self-induced irrigation water other other

Don't Know

8. Is the source being treated?

Yes

No

Don't know

9. Will the spread of these weed infections threaten the value or productivity of other lands?

Yes

No

Don't Know

10. Is your land currently being threatened by the infestation from other lands?

Yes No Don't Know

11. Are there sensitive areas in this unit adjacent to weed-infested areas? (mark "yes" by all that apply) Riparian habitat

Orchard Residential area Sensitive crops Recreational home Biocontrol site Cultural site

Don't Know 


\title{
Weed Management Area Status Report
}

\author{
(Annual Report)
}

Weed Management Area (WMA)

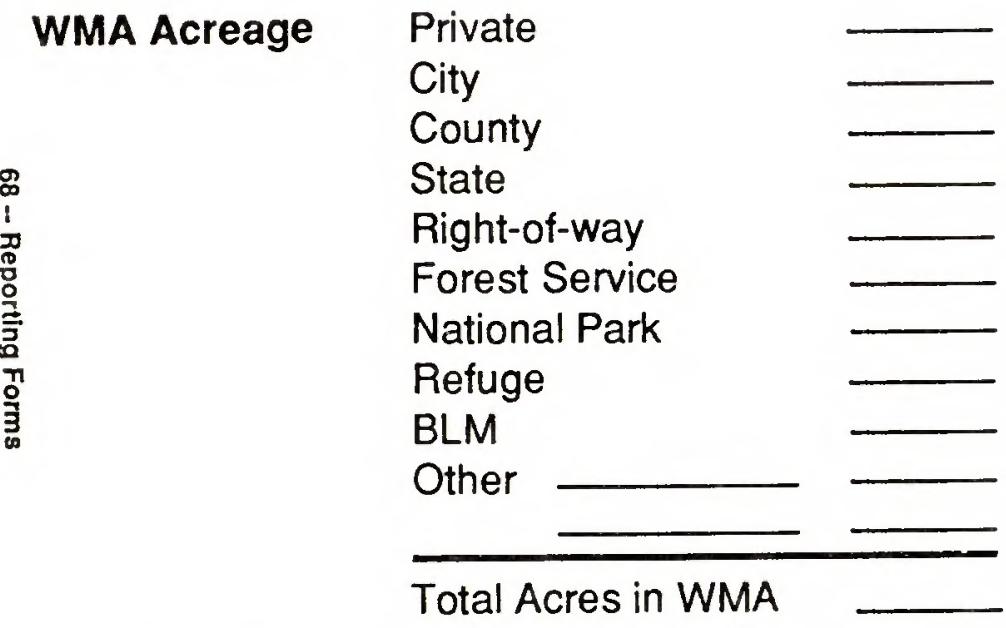

Submitted by

Address

Address

\section{WMA Organization Status:}

1. WMA Organized Yes

Date Title (See Section II, "Purpose and Organization of Weed Management Areas" for the five steps involved in organizing a WMA)

2. Management Plan Completed

Yes No No_ Date completed

3. Management Plan Approved by all WMA cooperators Yes No Date approved

\section{WMA Objectives Status:}

Please rate on a percentage basis the progress completed towards achieving the objectives for your WMA as detailed in your WMA Management Plan. A $100 \%$ rating indicates a successfully completed objective. "Funding required" equals funding needed to meet $100 \%$ of the WMA objective for the year approved.

\section{WMA Objective}

Percent
Completed

1. WMA Inventory Status (see Section V)

2. WMA Awareness, Education, Training (see Section III)

3. WMA Prevention and Early Detection (see Section IV)

4. WMA Acres Treated/Under Management (see Section VI)

5. WMA Monitoring \& Evaluation (see Section VIII)
Funding Required

\section{$\$$}

$\$$

$\$$

$\$$

$\$$ 


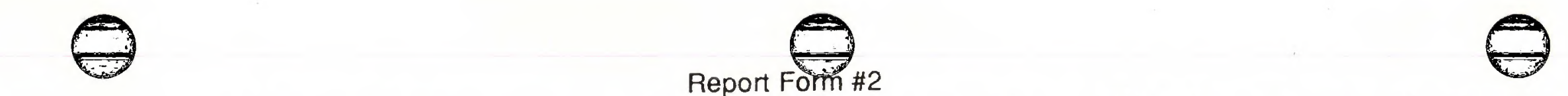

Noxious Weed Management By Species, Method, and Cost

(Annual Report)

Weed Management Area (WMA) Date

Submitted by Title

Address

Address

\begin{tabular}{|c|c|c|c|c|c|c|c|c|c|c|}
\hline \multirow{3}{*}{$\begin{array}{c}\text { Weed } \\
\text { Species }\end{array}$} & \multicolumn{8}{|c|}{ Management by Method, Acres, and Cost } & \multirow{3}{*}{$\begin{array}{l}\text { Total } \\
\text { Acres }\end{array}$} & \multirow{3}{*}{$\begin{array}{l}\text { Total } \\
\text { Cost }\end{array}$} \\
\hline & \multicolumn{2}{|c|}{ Biological } & \multicolumn{2}{|c|}{ Cultural } & \multicolumn{2}{|c|}{ Physical } & \multicolumn{2}{|c|}{ Chemical } & & \\
\hline & Acres & Cost & Acres & Cost & Acres & Cost & Acres & Cost & & \\
\hline & & & & & & & & & & \\
\hline & & & & & & & & & & \\
\hline & & & & & & & & & & \\
\hline & & & & & & & & & & \\
\hline & & & & & & & & & & \\
\hline & & & & & & & & & & \\
\hline & & & & & & & & & & \\
\hline & & & & & & & & & & \\
\hline Totals & & & & & & & & & & \\
\hline
\end{tabular}




\section{Noxious Weed Infested Acres By Level By Ownership}

(Report At 3-year Intervals, Beginning in 1991)

Weed Management Area (WMA) Date Submitted by Title

Address

Address

Refer to Section IV, Part III, and your inventory maps to complete this form

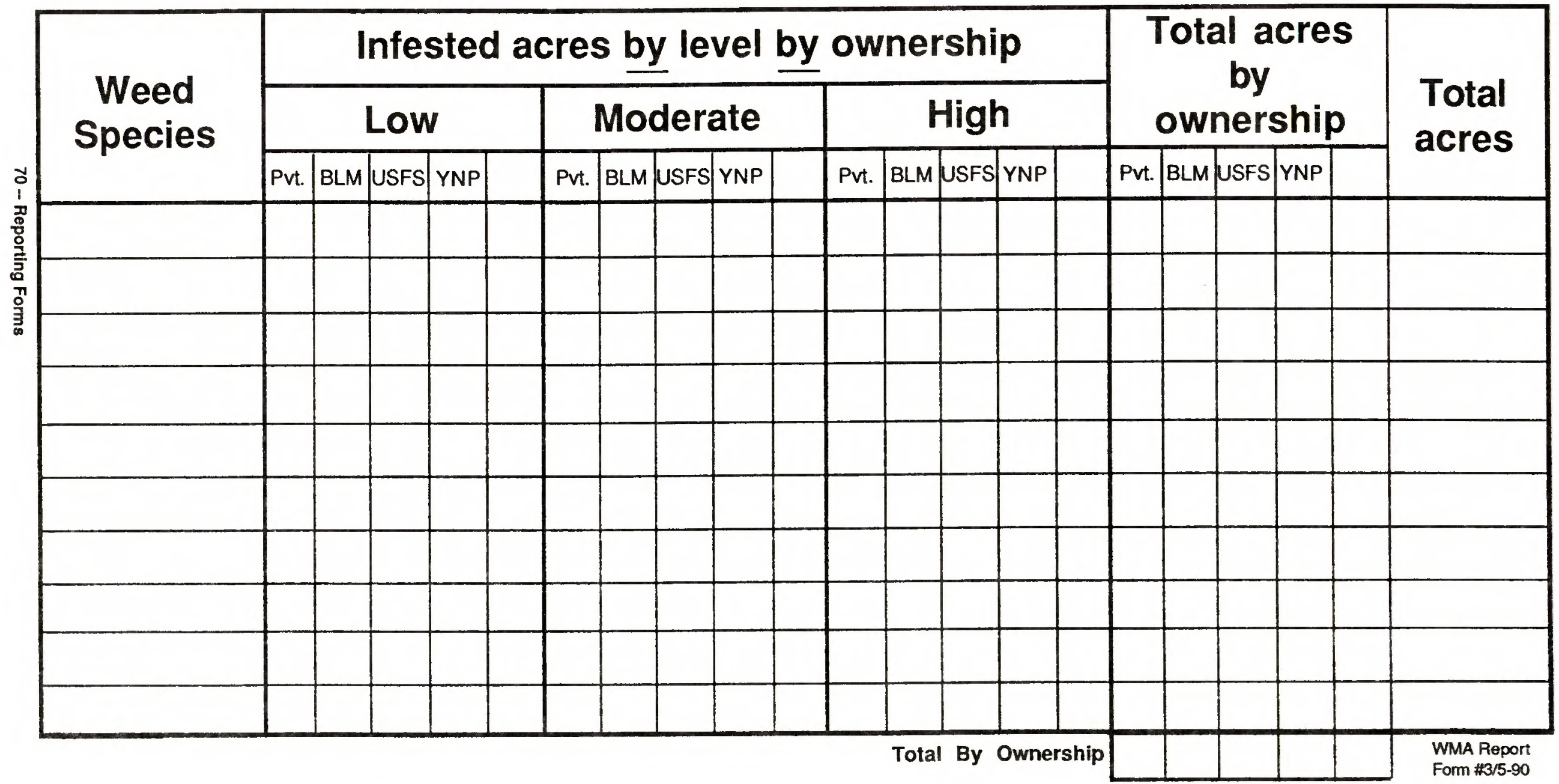




\section{Appendix 8}

\section{Monitoring Techniques}

This appendix provides guidelines for three types of noxious weed management monitoring techniques:

I. Permanent Photo Points

II. Vegetation Monitoring with Permanent Transects

III. Insect Biological Control Agents

Additional information on the monitoring techniques described in this appendix is available from university and government specialists. The information supplied here provides a useful starting point for developing successful weed management monitoring plans and programs.

I. Guidelines for Developing Permanent Photo Points

Permanent photo points are an easy and effective method to evaluate management actions and determine the progress of a weed control program. Comparing photographs of the same site taken over a period of years furnishes visual evidence of vegetation changes. Photo points should be established before initiating a control program in an area to ensure that there is a record of the resource situation prior to changes in management. Photographs, both closeup and general view, should be obtained at each evaluation site. IT IS VERY IMPORTANT TO ACCURATELY IDENTIFY EACH PHOTOGRAPH.

\section{A. Equipment}

1. Stakes ( $3 / 4$ inch angle iron at least 16 inches long)

2. Plot frame ( $3 \times 3$ or $5 \times 5$ foot metal frame)

3. Photo identification label (see attached)

4. $\quad 35 \mathrm{~mm}$ camera (ideally with a $28 \mathrm{~mm}$ wide-angle lens)

5. Color slide film

6. Metal post (for marking location of the site)

7. Post driver

8. Orange spray paint (for marking post)

9. Compass

B. Site Selection: At least one permanent photo point should be located in each KEY area. Key areas are "critical" sites within the project area where the proposed management should have a significant impact. The number of key areas needed in a project area will be influenced by soils, vegetation, topography, etc., and number of acres involved in the project. Key areas may be selected on the basis of environmental, social, and/or political criteria.

C. Procedures

1. Mark the key area with a permanent "transect location" post (spray post with orange paint). Locate a typical area about 25 feet from the "transect location post". Record the exact distance, compass heading and mark the plot with angle iron. This will be the permanent "close-up" photo print.

2. Number the site on the photo identification label. Locate the identification label in the center of the plot. Focus on ID label when taking photographs. 


\section{Appendix 8}

3. Timing: If possible, photographs should be taken when the weed is most visible (flowering).

4. Close-up Photographs: Place square frame within angle iron. Place the photo identification label flat on the ground. The camera point, or location from which the photograph is taken, should be on the north side of the photo plot so there will be no shadows across the photo. To take the photograph, stand over the photo plot with toes touching the edge of the frame. Include the photo label in the photograph.

5. General View Photographs: General view photographs present a broad view of a study site. The photo identification label is placed in an upright position so that it will appear in the foreground of the photograph. To take general view photographs, stand at the "transect location post", include the photo label, a general view of the site, and some sky in the photographs.

6. Repeat Photographs: Photographs should be taken at the same time each year using the above procedures. BE SURE TO USE THE SAME 35 MM CAMERA, COLOR SLIDE FILM, AND FACE THE SAME DIRECTION EACH YEAR WHEN TAKING REPEAT PHOTOS.

D. Narrative: A narrative must accompany each photograph so the results can be interpreted. A sample narrative is attached for reference. (Attachment A). The first 10 questions should be completed the first year. In subsequent years, questions $1,3,6,7,8,11$, and 12 should be completed.

E. Map: A map that shows the location of all project area photo points should be kept on file.

\section{ATTACHMENT A Photograph Narrative}

1. Photograph Identification Number

2. Date of photograph

3. Grazing use (estimate utilization)

$<33 \%$

$33-66 \%$

$>66 \%$

4. Soil surface texture

sandy

loamy

clay

other

5. Soil organic matter (optional) -- \%

A soil sample can be sent to the soil testing lab to determine organic matter if desired.

6. Herbicide application

Rate (gal./acre)

Surfactant: 


\section{Appendix 8}

Type of applicator: aerial handgun boom backpack

Applicator: county federal agency

state agency commercial

private (landowner)

7. Stage of growth of most important weeds at application

(check one) Weed Weed Weed

rosette (or shoot)

early bolt

pre bloom

flowering

post bloom

fall regrowth

8. Degree of infestation (what percent of total vegetation on the site is weed species)

$<10 \%$
$10-25$
$>25 \%$
Size of infestation (sprayed acres):
This is a key area because:

11. Percent weed control.

$<10 \%$

Weed

Weed

Weed

Weed

$10-30 \%$

$30-60 \%$

$60-90 \%$

$>90 \%$

12. Describe follow-up management (i.e. spot treatments, grazing management, etc.) 


\section{Appendix 8}

II. Vegetation Monitoring With a Permanent Transect
Permanent transects are an effective and accurate method to evaluate management actions and determine the progress of weed treatment projects. The purpose of a permanent transects is to monitor the treatment on the weed species and show over time the changes in vegetation. Only use this method if you have the need and objective to establish long-term monitoring.

Procedures for establishing these transects and collecting the data can be found In Indivlaual Federal Agency Hand books. The best method that Us.er noxilou, Weeds as indlcator plant species would be the Short Nested Microplot Method. This method would be specific to the Weeds of concern and limit the amount of time needed to read the transects.

Select those sites where the proposed management should have a significant impact on the vegetation and represents the project area. These should be established before initiating a treatment program in an area to ensure that there is a record of the resource situation prior to changes in management. These plots will be used on tours to explain the before and after situation and for evaluating program effectiveness. The location of permanent plots must be displayed on aerial photos and resource management maps. If the plots cannot be relocated they have no value in monitoring the change of vegetation over time. The location and number of permanent plots installed should be carefully considered because of the time and cost required for data collection.

\section{A. Sampling Methods}

There are several sampling methods available that can be located and marked on the ground for use as a permanent plot. The following methods may be used for predicting vegetation response to treatment, monitoring change over time, and determining canopy cover by species for ecological status. The procedures for carrying out these methods can be found in federal agency handbooks.

1. Density Method This method is designed to provide density (i.e., number per unit area) estimates of plant species, gopher mounds, pellet counts, and other important variables. Additionally, plant species density may be recorded by age-size class or some other class grouping. Sampling is usually conducted within five to seven transects which are randomly located along a macroplot baseline. Sampling may also be conducted within five to seven circular plots dependent on study needs. Transect lengths are usually 66 feet but may be changed depending on study needs. Counts of specific items (plant species, etc.) are made perpendicular to each transect line within a specified transect width. For example, a 2.2-foot width along a 66-foot transect line is equivalent to a $1 / 300$-acre plot. Density counts of an item collected within such a transect may be multiplied by 300 to obtain item number per acre. 


\section{Appendix 8}

2. Cover Microplot Method The Cover Microplot Method is designed to provide quantitative vegetation data at a plot. It is used when a replicated sampling design and statistical analysis are required or there is a need to calibrate ocular estimates. In this method canopy cover by species, ground cover, and production by life form are estimated through replicated sampling of microplots. A typical sample would contain 30 microplots along a $100 \mathrm{ft}$. transect. This method is not suitable for isolating the effects of climatic variability from management practices when describing changes in vegetation populations or composition with time.

3. Nested Microplot Method Nested Microplot Method is designed for statistically describing changes in vegetation over time, through use of nested rooted frequency measurements of plants. The same types of data are collected in this method as in the Cover Microplot Method with the addition of nested rooted frequency by plant species. It is the most suitable for isolating the effects of climatic variability from management practices when describing changes in vegetation composition over time.

4. Short Nested Microplot Method This method is used to record the same data contained in the Nested Microplot Method; however, only a few select plant species are sampled. This method will only sample the indicator plant species, such as the weed species and dominant grass, forb, or shrub species. A maximum of 12 species will be selected for sampling to detect changes over time. Data obtained by this method may be used for predicting vegetation response to treatment and monitoring change over time.

\section{B. General Features}

The location of permanent plots must be displayed on aerial photos and resource management maps. If the plots cannot be relocated they have no value in monitoring the change of vegetation over time. The location and number of permanent plots installed should be carefully considered. The purpose of a permanent plot is to monitor the treatment on the weed species and show over time the effectiveness of the method. Only use this method if you have the need and objective to establish long-term monitoring. Select those sites where the proposed management should have a significant impact and represents the project area. These should be established before initiating a treatment program in an area to ensure that there is a record of the resource situation prior to changes in management. These will be used on tours to explain the before and after situation and for evaluating program effectiveness. 
Complete a detailed, large scale, permanent plot description map for each plot with notes concerning:

1. How to locate the general area of the plot;

2. How to locate the transects;

3. A photo of the transects which includes reference background features.

4. Compass bearing of the transects and bearing to a reference point and distance.

5. Bearing of the transects from the Photo stake.

6. Location of stakes on the transects.

III. Insect $A$. Biological

Once a biological control agent has been released, it becomes necessary to determine:

1. What is occurring at the release site?

2. Did the agent becomes established?

3. Are its numbers increasing or declining?

4. Is this species acting as expected in its effect on the target organism?

5. Is the population of the target organism increasing or declining?

6. What are the biotic and abiotic forces acting on the bioagent?

7. What effect are these forces having on the newly released bioagent?

8. How does the agent interrelate with other established organisms?

B. The convenient method of answering these questions is to sample the locality to determine how the populations of the biocontrol agent and the target pest change, and in some cases, to observe the amount and type of damage actually inflected on the target host. The best method of sampling depends on:

1. How the agent utilizes its host.

2. The suspected density of the agent at the time of sampling.

3. The life cycle of both agent and host.

4. The desired accuracy of the data to be obtained.

5. The amount of effort, labor and money which can be expended on taking the samples.

C. Monitoring can be conducted in three ways:

1. Actively sampling the study area.

2. Attracting desired specimens to a trap.

3. Using a passive trap which collects whatever comes by.

D. Examples of active sampling include the following:

1. Observation -- The simplest, although also the least statistically reliable method of sampling, observation provides limited amounts of information. From this method you can learn:

a. that both the target organism and the agent are present. 


\section{Appendix 8}

b. what the agent is doing during the time that it is being observed.

c. the type and amount of damage inflected on the host.

d. how this damage has physically affected the host.

2. Daubenmyer/Ring Samples --When specific areas are to be sampled with exact results needed, squares, rectangles or rings of known area can be used. Daubenmyer plant sampling frames of specific size can be placed on the ground and all plant material within counted, measured, identified, clipped, sorted and/or weighed to determine the plant composition, canopy cover and biomass of the area.

3. Sweep Net Sampling -. Similar to observations, sweep net sampling is conducted when the agent is attracted to, or is in the vicinity of the host. With weed agents, this period is generally restricted to intervals when the agent is feeding on the flowers, leaves or stems, or when the adult bioagent is attempting to lay eggs.

With insect bioagents, the agents are most frequent in the vicinity of the prey/hosts when they are feeding or attempting to parasitize the target organism. Therefore, one must be familiar with the natural agent-host association and phenology.

4. Dissections -- When bioagents or parasites work within the host, both plant and insect host material can be collected and dissected. This provides information as to:

a. the infestation or infection rate of the host population.

b. the number of agents per given host.

c. stage of development of both agent and host

d. species composition of agents when numerous agents are involved.

e. location within the host where the agent resides.

$f$. the amount damage being inflected by the agents. If the sample size is sufficient, data will provide very accurate indications of the true agent and host population in the surrounding territory.

5. Suction or Vacuum -- Vacuums can be used to obtain live insets, spiders and mites from plants in the field. However, unless all plant material is strongly agitated in the suction area, and the soil area also vacuumed, many specimens may be missed. Some species are very difficult to dislodge from debris and vegetation. Therefore, this is not a reliable method to determine density unless the vegetation is checked afterwards to confirm that II organisms have been collected.

6. Before and After Photographs -- This is one of the simplest methods for recording results when working with biocontrol agents of weeds, but is useless when attempting to measure results of insect bioagents. This method does not provide information as to density of the target host, etc., but does display the end results. The photographic records are undeviating and 


\section{Appendix 8}

display dramatic, visual differences which generally have a greater impact on an audience than do dry figures and tables.

7. Digging -- Various stages of arthropods, nematodes, fungi, etc. can be located in the soil or in the root system of the target organism. Depending on the size of the organism being sought, various mesh screens can be used to sift the soil and expose the desired material, water can sometimes be used to float the specimens. Berlese funnels can drive the organisms into collecting traps, and dissections of the root material of the target plant can reveal the bioagent in its natural surroundings.

8. Berlese Funnel -- These are funnels with a heat source at the top cause the soil inhabiting organisms to try to escape the heat. They drive through the screen mesh or wire mesh material holding the soil, and fall through the funnel into a collecting container where they are generally killed. This is effective in collecting most soil inhabiting organisms including arthropods such as mites, spiders, insects, scorpions, etc.

9. Water Sorting -- Sampling for mites, nematodes and other small worms is often done by dissolving small soil samples in water and checking the fluid under a microscope. By knowing the volume of soil washed and the number of organisms obtained, one can calculate the density of the population. Often samples are taken at continuous levels to determine at what depth in the soil profile the species is most concentrated.

E. Examples of Attractant Traps

1. Black Light -- Black light traps are commonly used for attracting flying insects. Not all types of insects will be attracted to the light, because not all species see the same wave lengths of light. Moths and butterflies, flies, some beetles, lacewings, etc. are most often collected. The black light is generally operated at night.

2. Pheromone -- These are attractants, or odors which are most often species specific. Usually, they are sex attractants and lure only males or females. To calculate the amount of area that the pheromone covers, determine the approximate density of a population. Only minute quantities of material are needed which is carried for great distances on the breeze. This method can attract insects into cages where they can be live-trapped without harm.

3. Sound .- This method of attracting insects can also be used to determine the approximate density of a population if the organism can be attracted by sound and if one knows the area covered by the sound. Otherwise, like all other attractants, it only shows that there is something in the area at the time sampled. Sound is probably the least used sampling method and is generally very host specific. This method can be used for collecting live materials without having to handle it. 


\section{Appendix 8}

4. Entrance Traps -- These are screen traps with a passage which allows the organism to enter, but the portal is difficult to locate when it wishes to leave. These traps are often provided with some type of food attractant.

F. Passive Sampling Traps.

1. Pitfall Traps -- These are commonly cans, glass jars, or some other type of container which can be buried with the opening flush with the soil surface, and which can hold chemicals for killing the specimens. Because the preserving fluid can often evaporate and there is generally a long period of time between visits, regular antifreeze is often used.

2. Sticky Traps -- These are similar to the old sticky fly traps. A strip or board is covered with a non-drying sticky material and left in the vicinity of the target species. Sometimes a food attractant, such as sugar, is added, or a bright yellow or orange color is used which attracts many flying species.

\section{Notes:}




\section{Appendix 9}

\section{Noxious Weed Data Table}

This appendix expiains how to set up a Noxious Weed Data Table. The table may be constructed either by hand, by using a computer spreadsheet, or by using a computer database program.

Suggested Data Columns by Infestation Site

COLUMN \#1 Digit number, first digit is District number

COLUMN \#2 Drainage name, 20 spaces aipha

COLUMN \#3 1/4, $1 / 4$ of section, aipha, i.e., NW

COLUMN \#4 1/4 of section, one ietter indicates $1 / 2$ of section, l.e., NW, E

COLUMN \#5 Section number, 2 digits

COLUMN \#6 Township, aipha numeric, 3 spaces, i.e., $10 \mathrm{~N}$

COLUMN \#7 Range, alpha numeric, 3 spaces, i.e., 20W

COLUMN \#8 County, 3 digits, same as ail other data bases, i.e., Broad water is 007

COLUMN \#9 Road number

COLUMN \#10 Land use: grazing, timber, recreation, flower-picking

COLUMN \#11 Grazing allotment number, 3 digits

COLUMN \#12 Elevation, 5 numeric spaces, round off nearest 100'

COLUMN \#13 Aspect, 2 aipha spaces, i.e., NW

COLUMN \#14 Soil, 3 numeric spaces for landtype

COLUMN \#15 Distance to surface water, aipha numeric over 100' show as $100+$

COLUMN \#16 Distance to swamps or subirrigated areas, aipha numeric, over 100' show as $100+$

COLUMN \#17 Timber stand number, CIS 


\section{Appendix 9}

COLUMN \# 18

COLUMN \#19

COLUMN \#20

COLUMN \#21

COLUMN \#22

COLUMN \#23

COLUMN \#24

COLUMN \#25

COLUMN \#26
Species of weed or plant to be treated, by WSSA code (See Appendix 13):

EPHES (L. Spurge)

CIRAR (C. Thistle)

CADDR (Whitetop)

LINDA (D. Toadflax)

LINVU (Y. Toadflax)

ISATI (D. Woad)

CRUNU (M. Thistle)

SENJA (T. Ragwort) etc.

CONAR (F. Bindweed)

Acres, 2 spaces to the right of the decimal, 3 spaces to the left, for roads assume $100^{\prime}$ R-O-W

T\&E species, i.e., bald eagles, peregrine falcon

Canopy cover of noxious weeds, 1 space alpha

$\mathrm{L}=$ Low (less than 10\%)

$\mathrm{M}=$ Moderate (10-25\%)

$\mathrm{H}=$ Heavy (greater than 25\%)

Type of treatment, i.e., pesticides, mowing, grubbing, biological, burning

Chemical names, listed as follows:

TORDON TORDON/2,4-D TORDON/BANVEL ROUNDUP

Application rates of chemicals

Application method: BOOM, SPOT GRANULES

Date of treatment 


\section{Appendix 10}

\section{Site Information Worksheet}

1. Directions for filling out the Site Information Worksheet

Target weed - Use both the common and scientific names

Land use - General use of land included in treatment site (Rangeland, noncrop, right-of-way, etc.)

Infested acres - Use the same reporting method for the entire program

1. Total acres inspected while surveying, regardless of the number of weeds found per acre, or

2. Total number of acres within the management area that contain at least one target weed, or

3. Total amount of land physically inhabited by target weeds

II. Options A. Indirect IWM option Method - Indicate control method (Chemical, biological, physical, cultural)

B. Control Agent

1. Herbicide - List the common and chemical name

2. Biological - List the common and scientific name

3. Physical or Cultural - List equipment or manpower to be used

C. Rate per site

1. Herbicide - List the amount of active ingredient(s) and total number of units in accordance with label directions

2. Biological - List the number of insects, pathogen, head of livestock etc., which will be released per site

3. Physical or Management - List number of man-hours or equipment-hours per site or per acre

D. Number of releases or acres - Estimated (or actual) number of infested acres in this site or number of biological releases to be made at this site

E. Agent cost per unit - Estimated (or actual) cost of control agent per unit (gallon, pound, count, etc.)

F. Agent cost per site - Multiply the number of estimated releases or infested acres in this site by the cost per unit

G. Method of distribution or application - Method in which the control agent will be dispersed or applied (if applicable)

1. Herbicide - List type of application equipment to be used

2. Biological - List release method and/or methods for redistribution 


\section{Appendix 10}

H. Labor required per site or unit - Number of hours of labor required per site or acre for distribution or application (do not include administration time)

I. Labor cost per release or unit - Cost of labor per hour or release (include only the direct cost of application or distribution, not administrative costs)

1. Total labor cost - Multiply the estimated number of releases or infested acres by the labor cost per release or acre

K. Administrative cost per site - Total administrative costs of using this option

L. Total cost per site - Add agent cost per site, labor cost per site, and administrative cost per site

M. Effect on non-target species - Include if there is an adverse effect on non-target species with the use of this option

N. Expected percent of control first, second, third, fifth, and tenth year Use information from chemical companies, university studies, government studies, etc. 


\section{WMA Site Information Worksheet}

Weed Management Area (WMA)

Date

Site \#

Page \#

of

Completed by

\begin{tabular}{|l}
\hline Site Description \\
\hline Target Weed \\
\hline Land Use \\
\hline Infested Acres
\end{tabular}

Option \#1 Option \#2 Option \#3 Option \#4 Option \#5

Control Method

Control Agent

Rate (Units/Acres or Site)

\# of Acres or Releases

Agent Cost/Unit

Agent Cost/Site

Method of Distribution

or Application

Labor Required/Site-Acre

Labor Cost/Release-Unit

Total Labor Cost

Administrative Cost/Site

Total Treatment Cost

Effect On Non-Target Species

Exp. \% Control - 1st Year

Exp. \% Control - 2nd Year

Exp. \% Control - 5th Year

Exp. \% Control - 10 Year 


\title{
Appendix 11
}

\section{Guidelines for a Management Plan (MP) and an Annual Operating Plan (AOP)}

The following prototypes are examples of actual Management Plans and Annual Operating Plans used by the agencies listed under each plan.

Note: Any page or appendix references in the following examples are to pages or appendices within the sampies, not to other portions of the Guideilnes for Coordinated Management manual.

Remember that in actual weed management situations, not all the elements addressed in Section VI, "Management Plan/Annual Operating Plan", will necessarily be addressed in any one plan. Thus, the following prototypes serve only as examples as how completed plans will look in the specific situations described for each plan.

Your WMA objectives should answer the needs of your individual WMA and may not need to address all aspects of noxious weed management listed in the examples. The need for and prioritization of the following objectives will vary between WMAs. It is important to consider each of these core objectives, as success is greatest when an integrated plan is developed and implemented.
A. Develop and maintain an inventory
B. Develop and maintain funding and administration
C. Develop awareness, education, and training
D. Develop prevention and early detection programs
E. Develop long-term management objectives for weeds of con-
cern, according to CYA prioritization
F. Develop and maintain monitoring and evaluation
C. Develop and maintain a reporting system

1. Prototype

Management Plan (MP)

Summary

\author{
1. Mit. Hood National Forest \\ Noxious Weed Management Plan \\ January, 1990
}

Various noxious weeds are found at locations throughout the Mt. Hood National forest. These weeds pose a threat to the productivity of our National Forests and to adjacent agricultural lands. Forest lands can serve as a breeding ground for noxious weeds and provide a corridor for transfer of these weeds to adjacent agricultural lands. Noxious weed infestations can cause untold economic losses to agricultural and forest crop production as well as reduction in the value of the land for recreation, wildlife, and aesthetics. In cooperation with County and state government, the forest must implement a vigorous and effective control program.

This management plan identifies which weeds are priorities for control on particular portions of the Forest. Needs and methods for survey, control, and monitoring are included, as are objectives for developing a continuing, adequately funded noxious weed program.

\section{Overview}

Scope: This plan encompasses the entire Mt. Hood National Forest which is administratively divided into seven Ranger Districts.

Purpose: This plan describes goals and objectives and methods for controlling noxious weeds. It also identifies ways to develop adequate funding and establish cooperation with other agencies to effectively implement a program of prevention and control. 


\section{Appendix 11}

Pollcy: The Mt. Hood National Forest is committed to cooperating with State and County weed control agencies in controlling existing infestations and preventing the further encroachment of noxious weeds on the Forest that pose a threat to adjacent landowners and Forest land users.

Goal: 1. Control plants that have been identified as pests by the State Department of Agriculture.

2. Coordinate cooperative noxious weed control with State and County Weed Control agencies.

3. Finance the integrated noxious weed control program through multi-base funding and implement in the most cost effective method possible.

4. Identify, by species, the priority for control.

Objectives:

1. Prevent the eastward spread of Tansy Ragwort through intensive control measures (see map in appendix).

2. Prevent the westward expansion of the knapweeds through intensive control measures (see map in appendix).

3. Prevent the further expansion of Scotch Broom through intensive control measures on satellite infestations and use of biocontrols on established infestations.

4. identify the basis for prioritization for control.

5. Develop a coordination process that includes the State Department of Agriculture and formally organized County weed control districts (see appendix for list).

6. Develop a process for cooperation with all parties interested or concerned with noxious weed control on the Forest.

7. Develop a funding base utilizing Knutson-Vandenberg, Rangeland Betterment, Noxious Farm Weed and Road Maintenance Funds.

8. Conduct surveys to determine the distribution of noxious weeds, forest-wide.

9. Develop a process for reporting newinfestations of noxious weeds and maintaining an accurate data base.

10. Provide an education program for Forest personnel and visitors to assist in reporting and prevention of new noxious weed infestations.

11. Continue to develop support for and expand upon the use of biocontrol agents on the Forest.

Situation: Historical Background: The Mt. Hood National Forest comprises 1,059,456 acres. Human activity and fires have disturbed much of this acreage, creating conditions conducive to the invasion of pest weed species. Some of these noxious weeds are localized while others occur throughout the Forest. Effective control measure depend on accurate knowledge of distribution of noxious weeds. The primary concern is the threat these weed species pose for private agricultural lands adjacent to the Forest. In some instances control measures are instituted to protect forage values where noxious weeds have invaded range sites or to prevent livestock poisoning where grazing is permitted on the Forest. Seed from infested Forest land can be borne by wind, water, vehicles, and other means to agricultural lands which may result in increased costs and lowered crop quality and quantity. Noxious weeds also pose a threat to biodiversity on the Forest. Once established, pest weeds have the potential to crowd out native species and turn a plant community comprising a diverse assemblage of species into a virtual monoculture.

The Original Plan:

This management plan was initially organized in 1982 by a team of individuals from the Mt. Hood National Forest, Oregon Department of Agriculture, and respective counties within the Mt. Hood National forest boundary. This management plan established integrated control methods that were implemented at that time and are currently being used today with the exception of herbicide spraying. Chemical herbicides have not been used on the Forest since the 1984 ban, however prescribed spraying will resume as soon as implementation guidelines are established. Spraying for noxious weeds will be limited to hand spraying of carefully identified areas in accordance with the guidelines established in the Managing Competing and Unwanted Vegetation Final Environmental Impact Statement (Nov. 1988). 


\section{Appendix 11}

Major Forest Concerns:

The pest weeds that have been of most concern on the Forest are tansy ragwort (Senecio jocoboeo), Canada thistle (Cirsium arvense), the knapweeds (Centoureo spp.), and Scotch broom (Cystisus scoporius). Also of concern are rush skeletonweed (Chondrilla junceo), which was discovered on the Forest in 1989 on the Hood River Ranger District, and Gorse (Ulex europaeus), which was discovered adjacent to Forest Service land near Sandy in 1989. However if any of the weeds listed on the District detection lists are located they need to be eradicated before they have a chance to become established. Other species, such as holly (llex opoco or I. acquifolium) and ivy (Hedero helix), are beginning to show up on the Forest. These can both be aggressive species once established and may require treatment before they become a problem. Blackberry brambles (Rubus discolor) are taking over a few low elevation meadows and in one case may be encroaching upon a sensitive plant species.

Integrated Control

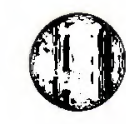
Strategles:

Control strategies have recently emphasized biological, manual, and cultural techniques. To date 15 different biological control agents have been released (see Appendix C pp. 20). Manual hand pulling of pest weeds has occurred in areas of critical concern (i.e. major travel corridors and satellite infestations) to prevent dispersal into uninfested areas. The planting of competitive species has also been attempted on the Forest.

Current Status of Priority Weeds:

Knapweeds have invaded the forest from the east and are steadily moving westward. The goal is to prevent their further movement into the Willamette Valley. These weeds are very aggressive and quite mobile due to their burr-like seed heads, which readily cling to many surfaces.

Tansy ragwort has spread throughout the Forest, with the heaviest infestations generally occurring west of the Cascade Crest. An intensive program has been initiated to eliminate the small infestations of tansy that have invaded the eastern portion of the Forest in recent years.

Scotch broom is an aggressive pest which is already well established across much of the Forest west of the Crest. Satellite infestations and new infestations along travel corridors will be intensively controlled.
Directions from other Documents:
Control measures specified in this document are specified under the direction of the Car son-Foley Act (PL 90-583) and the Federal Noxious Weed Act (PL93-629). State legislation relating to noxious weeds includes ORS 570.505 and RCW 17.10. Control measures will additionally be accomplished in accordance with Managing Competing and Unwanted Vegetation Final Environmental Impact Statement (Nov. 1988).

\section{Proposed Actions \\ To Meet Objectives:}

\section{Objective 1: Control Eastward Spread of Tansy Ragwort:}

The Barlow, Bear Springs, and Hood River Ranger Districts will coordinate and cooperate with the State Department of Agriculture and the Wasco and Hood River Weed Control Districts in implementing an intensive control program for tansy ragwort on the eastern half of the Forest (map in Appendix). The control line in the supplement provides a general guideline but specific control measures need to be implemented on a site-specific basis. This program will be coordinated with the Warm Springs Confederated Tribes through the Bureau of Indian Affairs. The secondary objective of this project will be to apply biological controls throughout the Forest where these species are beyond intensive control measures, primarily west of the Cascade Crest.

\section{Objective 2: Control Westward Spread of Knapweed:}

The Forest will cooperate with the State Department of Agriculture and appropriate Weed Control Districts in applying intensive strategies west of the control line to prevent any further extension of knapweed. The control line provides a general guideline but specific control measures need to be implemented on a site-specific basis. 


\section{Appendix 11}

\section{Objective 3: Control Further Expansion of Scotch Broom:}

The Forest will cooperate with the State Department of Agriculture and appropriate Weed Control Districts in applying intensive strategies in the control of satellite infestations of Scotch broom as well as manageable infestations that occur along travel corridors. Biocontrols will continue to be used on large established populations.

\section{Objective 4: Apply Controi Measures on a Priority Basis:}

Noxious weed programs will be directed at controlling weed species listed as A, B or Detection pests. Priority will be given to controlling " $A$ " rated weeds and Detection weeds through intensive methods. " $B$ " rated weeds will be controlled by less intensive methods, primarily the use of biological agents. Determination of priority will be coordinated through the Supervisor's Office. See pp. 10-17 for lists.

\section{Objectlve 5: Control Program Coordination:}

The forest and all Ranger Districts will coordinate their noxious weed programs and projects with the State Department of Agriculture, and where established, with County Weed Control Districts. This may be accomplished by working closely with and maintaining open communications with these organizations. A meeting involving appropriate forest, County and State personnel will be held each year, and an annual forest summary of activities will be produced by the Forest Noxious Weed Coordinator. See list in appendix of organized weed control districts.

\section{Objective 6: Cooperation:}

Provide information and cooper ate with other parties who may be concerned with or interested in the Noxious Weed Program on the Forest. See partial listing in appendix.

\section{Objective 7: Develop Funding Base}

Each timber sale should be evaluated in light of past experience or potential hazard to provide conditions suitable for the invasion of noxious weeds. Knutson-Vandenberg funds $(K-V)$, can be programmed through the Sale Area Improvement Program to mitigate any adverse effects of the harves activities.

Noxious weed problems can be controlled through the use of monies provided by Protection and Maintenance ( $P \& M)$, Range Revegetation or Rangeland Betterment funds. Noxious weed control projects, within Range allotments, should be identified in the allotment plan and listed as proposed range improvement work. Where noxious weed invasion/distribution is associated with road rights-of-way, Road Maintenance funds can be used for control. Since truck traffic related to logging has the greatest potential for spreading noxious weeds, funding will primarily come from the Coop deposit account, though FR\&T funding may also be available.

\section{Objective 8: Conduct Surveys}

Establishment of priorities and appropriate levels of funding depends on accurate assessment of the distribution of noxious weeds. Surveys can be accomplished by forest Service personnel and through cooperation with the State Department of Agriculture and County Weed Control District.

\section{Objective 9: Reporting Process and Data Base Creation}

A step-by-step process for reporting noxious weed infestations will be developed by the Oregon Department of Agriculture and the Forest Service. A summary of treatments employed and posttreatment evaluation of infestations also needs to be compiled in a central computer data base. This data base will provide a measure of program needs and accomplishments.

\section{Objective 10: Education}

An ongoing program of training for District personnel needs to be established to assist in the reporting and prevention of new noxious weed infestations. This can be accornplished by making training materials available (see Appendix D) and the Oregon Department of Agriculture is available to provide training sessions on Districts. 


\section{Appendix 11}

Detection of Noxious Weed Infestations

Reporting Process for Weed Sightings:

Forest Priority for Noxious Weed Control:

Integrated Control Methods

\section{Objective 11: Blocontrol Program}

The Forest will continue to work with Oregon Department of Agriculture to expand on the used of biological agents on the Forest. The Forest will also cooperatively with the State develop a monitoring program to access the efficacy of biocontrol use.

Surveys for Noxious Weeds: Some noxious weed species lend themselves to aerial detection methods using helicopters. Tansy ragwort, when in bloom, can be readily identified by trained observers, and the use of helicopters permits relatively quick coverage of large areas. Trained observers are a necessity, but their training is fairly simple and brief.

Ground surveys or detection methods can be accomplished in many instances by alerting regular Forest personnel to recognize noxious weed species on sight or by having them collect samples of suspected plants to be identified by other qualified people on the Ranger District. Posters, booklets, color photographs, video and slide programs are available and can all be effectively used to train District personnel to recognize and identify noxious weeds. The Oregon Department of Agriculture is available to provide training in the identification of noxious weeds as well as to answer any questions that arise.

Report all infestations of Detection and " $A$ " rated weeds to the Ranger District Contact person. Include the following information: 1 - weed species; 2 - location (T-R-Sec., road number, etc.); 3 - size of infestation (appropriate number of plants, or acres, etc.); 4 - site type (roadside, clear cut, log landing, meadow, etc.).

Also, it may be appropriate to make note of major problem areas of "B" rated weeds on your District so control measures can be implemented.

The District Contact will compile this information and pass it along to the Supervisor's Office and the Oregon Department of Agriculture so appropriate action can be taken.

A step-by-step reporting process will be developed by the Oregon Department of Agriculture and Forest Service for use on the District.

Within the Forest Policy framework the Forest has established priorities for implementing or continuing noxious weed programs and allocating funds available for this purpose. The Mt. Hood National Forest priorities are:

Priority 1: To prevent the establishment of Detection rated weeds (see District lists, pp. 1017) and immediately eradicate with intensive control methods all new infestations.

Priority 2: To control or prevent the further expansion of " $A$ " rated weeds (see District lists, pp. 10-17) using intensive control methods where appropriate.

Priority 3: To control or prevent the establishment of " $B$ " rated weeds (see District lists, pp. 10-17) using primarily biocontrol agents where available.

In addition to following the priorities established for funding noxious weed programs, the Forest will favor projects where State or County Weed Control Agencies are cooperatively participating in control activities. Each Ranger District is encouraged to work closely with State or local County Weed Control agencies in developing noxious weed programs that meet mutual goals and objectives. Effective programs must include companion projects both on and off the Forest in most instances.

A full range of alternatives is available to develop prescriptions for the control of noxious weeds. The se consist of cultural, mechanical, manual, prescribed fire, biological, chemical, and regulatory strategies used singularly or in combination. The control methods must be tailored to meet the goals and objectives established for the noxious weed program and in addition be compatible with other resource values and uses. 


\section{Appendix 11}

Use of Cultura!, Mechanical, and Manual Methods: Cultural methods entail the use of competitive plantings of desirable species in disturbed areas to prevent noxious weeds from being able to become established. Mechanical methods, including mowing, cutting, and tilling, can be used to contain the spread of noxious weeds by reducing seed production and vigor. Mechanical methods may not be appropriate for species which spread by rootstocks. Hand pulling, digging, and clipping are all manual methods that have been used extensively in recent years.

Use of Prescrlbed Fire: Burning can be used to kill annual weeds and contain the spread of perennial herbs and shrubs. However, the ability to use fire effectively is predicated upon having a population dense enough and large enough to carry a fire.

Use of Biological Controis: The ability of introduced noxious weeds to invade areas is enhanced by the absence of naturally occurring pathogens in the area into which they've infested. Use of biological controls involves collecting naturally occurring pathogens of specific weeds and redistributing them in areas where the weed has become established. Before any biocontrol is introduced into an area it has been thoroughly studied to evaluate it's effect upon the ecosystem into which it is being introduced.

Use of Chemical Herbicides: Chemical herbicides have not been used on the National Forest since the 1984 ban. This ban has recently been lifted but the process for herbicide implementation remains to be formalized. Sixteen herbicides were considered for use by the Forest Service but only 13 have been selected for use. These are asulam, atrazine, bromacil, 2,4-D, 2,4-DP (dichloprop), dalapon, dicamba, glyphophate, hexaxinone, picloram, simazine, tebuthiuron, and triclopyr. of these 13, 2,4-D is allowed only as a last resort and most of the others carry restrictions for use in addition to the EPA label instructions. Decamba, picloram, and triclopyr are the three that will be most applicable for noxious weeds on the forest. There are also additional restrictions involving the use of kerosene and diesel oil as carriers. Any use of herbicides will be implemented in strict accordance the guidelines established in Managing Competing and Unwanted Vegetation Final Environmental Impact Statement (Nov. 1988).

Post Treatment Needs:

Monitoring of Treatments: Monitoring will be carried out as an integral part of representative projects to determine the effectiveness of the prescribed treatment that has been applied. The Forest is currently finalizing a Memorandum of Understanding with the Oregon Department of Agriculture to establish a five-year project starting in $\mathrm{FY} 90$ to monitor the effectiveness of biological controls that have been established on the Forest. The effectiveness of all cultural, mechanical, and manual treatments needs to be assessed as a part of the follow up treatment. Chemical herbicide treatments will require post-treatment assessment of effectiveness and will be done in accordance with the guidelines established in Managing Competing and Unwanted Vegetation Final Environment Impact Statement (Nov. 1988)

Reporting of Treatments: The District Contacts will be responsible for compiling information on the treatments undertaken on their District that year. The information should include the date, location, acreage, and amount of treatment (i.e. numbers of insects released, numbers of plants pulled, volume and mix of herbicides, etc.). Treatments will be reported by the Forest range conservationist on Range Improvement Forms (FS-220-127) via FRAMIS. Each Ranger District should be reported as a single allotment. A Forest-wide computer data base should be developed to provide a quick and accurate reference to what's been done and serve as a guide in directing future treatments.

Role and Responsibilities of Agencles Involved:

\section{Forest Supervisor's Office Responsibilitles:}

1. Management and development of budget and distribution of monies to the Districts.

2. Coordinate Forest-wide noxious weed programs with the Oregon Department of Agriculture, including formation of contracts and MOUs.

3. Compilation of survey and site reporting data as well as data regarding treatments in a central computer data base.

4. Provide direction to District noxious weed programs. 


\title{
Appendix 11
}

\author{
Ranger District Contact Responsibilities: \\ 1. Coordinate noxious weed control activities on the District. \\ 2. Act as a contact person for the Supervisor's Office, Oregon Department of \\ Agriculture and County. \\ Attend annual coordination meeting with Forest Service, Oregon \\ Department of Agriculture, and County. \\ 3. Act as a resource and information source for District personnel. \\ Heighten district employees awareness of the consequences of noxious weed \\ infestations. \\ Assist district employees in identification of target species. \\ Direct district employees as to how to report noxious weed sightings to the \\ district coordinator. \\ Schedule district noxious weed training and request trainers from ODA. \\ 4. Provide noxious weed input and/or mitigation measures to project NEPA \\ documents (i.e. timber sale and Project Opportunity Area EAs, pit development \\ EAs, etc.). \\ Prepare K-V plan to collect funds for control of noxious weeds. \\ 5. Maintain and update files and records regarding noxious weed sightings, \\ treatment, and budget. \\ Report annually to Forest Range conservationist any treatment activity. Include \\ the species treated, type of treatment, type and amount of funds expended to \\ do the work, acres of ground treated. Compile noxious weed sighting informa- \\ tion according to suggested reporting method.
}

\section{Role of Oregon Department of Agricuiture:}

1. Act as an informal resource for the noxious weed program on the Forest.

2. Coordinate programs between the Supervisor's Office, Ranger Districts, and the County.

3. Produce annual report of noxious weed treatment accomplished under Forest Service contract.

4. Provide expertise in integrated control methods, i.e. biological, prevention, manual, mechanical, cultural, and chemical.

5. Provide expertise in developing target and detection noxious weed lists for the Forest.

6. Provide education in the form of training sessions to Forest personnel, i.e., weed identification, control methods, and overall program emphasis.

7. Coordinate monitoning, collection and redistribution of biological control agents.

\section{Role of County:}

1. Report all control activities to the Oregon Department of Agriculture for inclusion in annual report.

2. Implement control and monitoring projects identified by the Oregon Department of Agriculture and Ranger Districts.

3. Coordinate all noxious weed management activities through the Oregon Department of Agriculture and appropriate Range Districts.

4. Act as a resource and provide noxious weed control and identification expertise to appropriate Ranger Districts.

Mt. Hood National Forest Noxious Weed Classification System

\section{Noxlous weeds are rated A, B, and Detected.}

1. "A" Rated weed: A weed of known economic importance of of limited distribution in the State of Oregon and/or in a Mt. Hood National Forest Ranger District, and is subject to intensive control or eradication where feasible at the Ranger District level.

2. " $B$ " Rated weed: A weed of known economic importance that is widely distributed on the Mt. Hood National Forest and is subject to control where feasible at the District level. 


\section{Appendix 11}

3. Detected weed: A weed of known economic importance known to occur in the State of Oregon in small infestations to make eradication practical and not known to occur in a Mt. Hood National Forest Ranger District.

Action: if found to occur in the Mt. Hood National Forest, this weed is to be placed on the appropriate A or $B$ list.

\section{Barlow Ranger District}

\begin{tabular}{|c|c|}
\hline $\begin{array}{l}\text { Tansy Ragwort } \\
\text { Spotted Knapweed }\end{array}$ & $\begin{array}{l}\text { Senecio jacobaea } \\
\text { Centaurea maculosa }\end{array}$ \\
\hline $\begin{array}{l}\text { Canada Thistle } \\
\text { St. Johnswort } \\
\text { Scotch Broom } \\
\text { Diffuse Knapweed }\end{array}$ & $\begin{array}{l}\text { Cirsium arvense } \\
\text { Hypericum perforatum } \\
\text { Cystisus scoparius } \\
\text { Centaurea diffusa }\end{array}$ \\
\hline $\begin{array}{l}\text { Corse Detected weeds } \\
\text { Dalmatian Toadflax } \\
\text { Leafy Spurge } \\
\text { Musk Thistle } \\
\text { Rush Skeletonweed } \\
\text { Yellow Starthistle } \\
\text { Russian Knapweed } \\
\text { Brown/Meadow Knapweed } \\
\text { Purple Loosestrife } \\
\text { Poison Hemlock } \\
\text { Perennial Pepperweed }\end{array}$ & $\begin{array}{l}\text { Ulex eropaeus } \\
\text { Linaria dalamatica } \\
\text { Euphorbia escula } \\
\text { Carduus nutans } \\
\text { Chondrilla juncea } \\
\text { Centaurea solstitialis } \\
\text { Acroptilon repens } \\
\text { Centaurrea jacea/C. pratensis } \\
\text { Lythrum salicaria } \\
\text { Conium maculatum } \\
\text { Lepidium latifolium }\end{array}$ \\
\hline
\end{tabular}

These lists are subject to change at the Forest Supervisor's discretion.

\section{Columbla Corge Ranger Distrlct}

A rated weeds

Diffuse Knapweed

Spotted Knapweed

Scotch Broom

B rated weeds

St. Johnswort

Canada Thistle

Tansy Ragwort

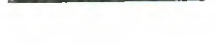

Detected weeds

Gorse

Dalmatian Toadflax

Leafy Spurge

Musk Thistle

Rush Skeletonweed

Russian Knapweed

Yellow Starthistle
Centaurea maculosa

Cystisus scoparius

Hypericum perforatum

Cirsium arvense

Senecio jacobea

Ulex europaeus

Linaria dalmatica

Euphorbia escula

Carduus nutans

Chondrilla juncea

Acroptilon repens

Centaurea solstitialis

These lists are subject to change at the Forest Supervisor's discretion. 


\title{
Appendix 11
}

\author{
2. Clarks Fork Weed Management Area (CFWMA) \\ Management Plan \\ 1990
}

\section{Define/Describe the WMA}

The CFWMA includes all the land within the drainage area of the Clarks Fork of the Yellowstone River; from the headwaters to its emergence from the Clarks Fork Canyon near Clark, Wyoming. Excluded from the CFWMA are the highway rights-of-way under the jurisdiction of the Montana and Wyoming Highway Departments and those portions of the Beartooth Highway under the jurisdiction of Yellowstone National Park. (Noxious weed control for these excluded areas will be addressed under a separate WMA).

Included in the CFWMA are lands within the legal boundaries of the Wyoming county of Park and the Montana counties of Park and Carbon. Legal jurisdiction of public lands include the U.S. Forest Districts of Clarks Fork and Gallatin, the Absaroka-Beartooth Wilderness, and the Wyoming Game and Fish Department. Private lands include ranches, tourist facilities, seasonal cabins, subdivisions, incorporated townsites, and private game sanctuaries.

Recreation is the Major use of the lands within the CFWMA. Activities include sight-seeing, big game hunting, camping, snowmobiling, back country hiking, and fishing. Agricultural uses include ranching, hay production, and livestock grazing of both sheep and cattle. Commercial uses include tourism, lumber production, and commerce.

The topography consists of mountains and intermountain valleys. The elevation varies from 12,799 feet at Cranite Peak to less than 5,000 feet at the mouth of the Clarks Fork Canyon. All species of North American wildlife are found in the area. Some of the lower areas serve as a wintering and calving range for the Yellowstone elk herds. Mule deer, moose, and big horn sheep are also found in the area included in the CFWMA. Numerous high mountain lakes and streams support many fish species including arctic grayling, brook, cutthroat, rainbow, brown, lake, and golden trout.

Vegetation is typical to that found in high mountain meadows, and the forests include a variety of pine trees and aspen. Cultivated lands are usually planted to a mixture of grasses and legumes which are either grazed or harvested for livestock and wildlife feed. Irrigation is limited to flood irrigation from water diverted from either streams or rivers.

The CFWMA is heavily impacted during the summer months by tourists entering or leaving Yellowstone National Park (YNP) by the Northeast entrance. The town of Cooke City provides commerce for the tourists and residents of the area. Both the Beartooth and the Chief Joseph highways are designated as scenic highways and are recommended tour routes by many private and public information agencies. Small subdivisions have been established on several parcels of private land, and seasonal cabins and houses are found on both private and special use public lands.

Define Purpose of WMA Management

Plan

\author{
Define WMA
Objectives \\ efine WMA
Objectives
}

This management plan is established to comply with the concept of a master plan for noxious weed control in the Greater Yellowstone Area (CYA). It is intended to concentrate available resources and capital on the noxious weed problem regardless of political boundaries. Through the cooperation of all agencies and individuals involved, it is the objective of this plan to prevent, contain, reduce, and hopefully eradicate noxious weeds in the Clarks Fork Weed Management Area (CFWMA).

\section{Objective \#1: Develop and maintain an inventory}

Mapping and documenting noxious weed infestations will be executed in the manner described in Section V, "Inventory." (Additional guidelines will be obtained from Noxious Weed Management Planning Cuidelines Workbook available from by Ag West Communications, Ft. Collins, CO) The agencies involved will be responsible for furnishing the required topography maps for the lands under their jurisdiction. The maps will be updated on a regular basis with newly reported infestations and previously treated areas clearly indicated. All agencies will offer input into the location and types of infestation. The Clarks Fork Ranger District is responsible for updating and maintaining the maps. 


\section{Appendix 11}

\section{Objective \#2: Deveiop awareness, education, and training}

Concern for the control of these noxious weed have been expressed from several different factions of the population. Livestock producers find these weed compete with the more nutritious and palatable plants used by their grazing animals. In addition, the movement of these weeds onto lands not previously infested is a real concern. Hunters and other people interested in the recreation opportunities found in the CFWMA, are concerned about the loss of habitat and feed for the wildlife. Because most of these weeds have no or few natural enemies, they have the potential of multiplying and disrupting the present ecosystem.

\section{Objective 3: Spotted knapweed}

Because of its potential to spread, Spotted knapweed is the weed of major concern. There is a vast seed source of this weed in areas adjacent to the CFWMA which is introduced into the management area by vehicles and mankind. Failure to control just one infestation within the management area will produce a seed source which will cause an increase the total number of infested acres in the CFWMA.

\section{Objective 4: Gravel pits}

Two gravel pits within the CFWMA have been identified as having infestations of specific noxious weeds not known to existed anywhere else in the area. Musk thistle was first identified at the temporary gravel storage area at the base of Dead Indian Pass in 1979 and Spotted knapweed was known be present in the Pilot Creek gravel pit as early as 1977.

\section{Objective \#5: Ox-eye daisy and Daimatian toadflax}

Plants such as $\mathrm{Ox}$-eye daisy and Dalmatian toadflax are easily disseminated by tourist and residents picking the flower for its aesthetic value. Ox-eye daisy is found west of the CFWMA and Dalmatian toadflax is a major weed problem in the Mammoth area of YNP. The most abundant weed found in the CFWMA is Canada thistle. However, it has become so established that eradication is no longer a viable option and only containment and reduction should be considered with available methods.

\section{Objectlve \#6: Trailheads}

Another source of infestation seem to be near trailheads were horses and other livestock are unloaded from vehicles, held in confinement for a period of time and fed unprocessed feeds such as hay. Other infestations have been reported along heavily used trails of both livestock and wild life. Both the disturbance of soil and the introduction of noxious weeds through animal waste cause an increase in noxious weed infestations.

Define WMA Weeds of Concern

Noxious weeds have been introduced into the CFWMA from a variety of sources. The most obvious infestations seem to have started along the highway rights-of-way. This is supported by visual observations of noxious weeds such as $\mathrm{Ox}$-eye daisy and spotted knapweed being found along the Beartooth and Chief Joseph Scenic Highways and nowhere else in the CFWMA.

Many other infestations have been identified in areas that have been disturbed by man. Areas where timber sales have occurred are often heavily infested with noxious weeds. The combination of removing the native vegetation for the building of roads, reducing soil compaction by disturbing the soil, the introduction of noxious weed seeds from contaminated equipment, and the increased amount of light being allowed to contact the ground because of the removal of the trees, all enhance the introduction, growth, and increase of noxious weeds.

Noxious weeds known to exist in the CFWMA included:

Canada thistle (Circium arvense)

Common burdock (Arctium minus)

Dalmatian toadflax (Linaria dalmatica)

Field bindweed (Convolvus arvensis)

Hoary cress (Cardaria draba)

Houndstongue (Cynoglossum officinale)

Musk thistle (Carduus nutans) 


\section{Appendix 11}

Define WMA Pollcy
Ox-eye daisy (Chrysanthemum leucanthemum)

Perennial sowthistle (Sonchus arvensis)

Spotted knapweed (Centaurea maculosa)

Yellow toadflax (Linaria vulgaris)

1. Commitment to use of Integrated Weed Management:

A complete integrated weed management (IWM) system shall be implement in accordance with the guidelines in Section VII. Each infestation wil! be evaluated based on location, species of weed, non-target vegetation intended land use, and topography. The actual control method to be used on each infestation will be stated in the yearly action plan. Pesticide application will be in accordance with label instructions and all safety precautions specified in the material safety data sheets (MSDS) shall be followed. A comprehensive safety plan shall be established and followed (See Appendix 12)

2. Establish adherence to management of noxious weeds in accordance with GYA priorities:

Priorities will be based on two considerations. The first consideration will be the weed species and its potential of spreading to areas not previously infested. Weeds which have not been previously detected or are found in small, isolated spots within the CFWMA will receive first priority. Attempts will be made to eradicate the new infestation and to determine the source. If possible, control measures will be implemented to prevent re-infestation.

The second basis for priority of weed control practices will be the location of the infestation in relationship to topography and usage by man and livestock. Infestations at the head of water sheds, along trails of high seasonal use, and areas of intense grazing are the types of areas which shall receive first consideration when initiating a plan of work.

\section{Proto- Clarksfork Weed manacement area (CFWMa) type Annual 1990 Annual Operating Plan}

Operating $A$. Plan (AOP)

A. Define Roles and Responsibilities

Agencies directly involved with the CFWMA by providing funding, resources, or expertise include:

Park County Weed and Pest Control District, Powell, WY

Park County Weed District, Livingston, MT

Carbon County Weed District, Joliet, MT

Wyoming Department of Agriculture, Cheyenne, WY

Montana Agriculture Department, Helena, MT

Shoshone National Forest, Clarksfork Dist., Powell,WY

Gallatin National Forest, Gardiner Dist., Gardiner, MT

Wyoming Game and Fish Department, Cheyenne, WY

University of Wyoming, Laramie, WY

Montana State University, Bozeman, MT

B. Define signatures required

(Title), Park County Weed and Pest Control District

(Title), Park County Weed Control District

(Title), Carbon County Weed Control District

(Title), Wyoming Game and Fish Department

(Title), University of Wyoming

(Title), Shoshone Nat'l Forest Clarksfork Ranger District

(Title), Gallatin Nat'l Forest Gardiner Ranger District

(Title), Wyoming Department of Agriculture 
(Title), Montana Department of Agriculture

(Title), Montana State University

C. Define terms and time of termination

This management plan shall remain in affect until terminated by mutual consent of the agencies involved.

Agencies that have been consulted and will be included in long range planning include: Yellowstone National Park, Mammoth, YNP

Custer National Forest, Beartooth District, Red Lodge, MT

Wyoming Highway Department, Cody maintenance area, Cody, WY

Greater Yellowstone Coordinating Committee, Billings, MT

Townsite of Cooke City, Cooke City, MT

Wyoming Highway Patrol, Cheyenne, WY

Montana Highway Patrol, Helena, MT

Wyoming State Extension Service, Laramie and Cody, WY

Montana State Extension Service, Bozeman and Livingston, MT

D. Define Annual Funding and Resource Availability

The following agencies agree to provide:

Park County Weed and Pest Control District (PCWPCD), Powell, WY

1. The cost of all pesticides used in the chemical treatment of Spotted knapweed

2. The administration to implement, coordinate, and carry-out the CFWMA management plan

3. Application equipment (under contract to PCWPCD) for the chemical treatment of noxious weeds in the CFWMA. The first 20 hours will be without remuneration. The balance of the application time will be reimbursed at actual cost.

Park County Weed District, Livingston, MT

1. Use of their application equipment. The first 20 hours will be without remuneration. The balance of time will be reimbursed at actual cost.

2. The cost of all pesticides used in treatment of Dalmatian toadflax

Carbon County Weed District, Jollet, MT

1. Use of their application equipment. The first 20 hours will be without remuneration. The balance of time will be reimbursed at actual costs.

2. The cost of all pesticides used in treatment of Leafy spurge

Wyoming Department of Agriculture, Cheyenne, WY

1. Printing, copying and mailing cost associated with the producing both the management plan and the action plan for the CFWMA

Montana Agriculture Department, Heiena, MT

1. The cost of creating, printing and distributing a brochure explaining the concept of a management plan for the CFWMA

Shoshone Nationai Forest, Clarks Fork District, Powell, WY

1. $\$ 3500.00$ toward the cost of pesticide control

2. $\$ \$ 00.00$ toward the cost of introduction of biological control into the CFWMA

Galiatin National Forest, Cardiner District, Gardiner, MT

1. $\$ 2000.00$ toward the cost of pesticide control

2. $\$ 500.00$ toward the introduction of biological control into the CFWMA

Wyoming Game and Fish Department, Cheyenne, WY

1. $\$ \$ 00.00$ toward the cost of pesticide control

2. $\$ 500 . / 00$ toward the introduction of biological control into the CFWMA

University of Wyoming, Laramie, WY

1. One pesticide control research plot

Montana State University, Bozeman, MT

1. One biological control research plot 


\section{Appendix 11}

E. Define Proposed Actions To Meet Annual Objectives

1. Chemical treatment may include Tordon 22K, Banvel, or Stinger, or 2,4-D. The selection of pesticide will be determined on-site by using the "Turn Around, Look Around" method of decision making recommended in the video film of the same name. All pesticides will be used within recommended label rates as suggested by the University of Wyoming's Recommended Weed Control Guide.

2. Mechanical control practices will be limited to those areas where single plants or small patches of spotted knapweed are located. After chemical treatment, seed heads will be removed and carried to an area safe for burning. Removal of the entire plant or seed head will be conducted only if it is reasonable for the existing situation.

3. Preventative plans shall include the adoption of the recommended "Weed Free Certification Program" originated by the Wyoming Department of Agriculture. Specific plans shall be finalized through cooperation with the Forest Service, the Park County Weed and Pest Control District, the Park County Sheriff 's department, and the Wyoming and Montana Highway Patrol. All livestock and wildlife feed introduced into the CFWMA shall meet the standards of the "Weed Free Certification Program."

4. Biological control will include the introduction of approved insects or pathogens on known areas of Canada thistle. The Montana State Extension Service shall supply the recommendations and the control agent introduction will be made by the Park County (MT) Extension Service.

5. Chemical control will continue with emphasis on new infestations or small areas of weeds. Retreatment will be conducted as needed and variety of approved products will be used to prevent the chance of developing plant resistance.

6. Mechanical control will be used when seed head removal is a viable control method or non-target vegetation prevents the use of herbicides. Because labor in mechanical control is so costly, hand labor will only be used in areas of high priority and high sensitivity.

7. Preventative methods will continue to be implemented whenever possible. The "Weed Free Certification Program" will continue to be enforced and cooperative agreements entered into with enforcement agencies. The Wyoming and Montana Extension Services will present education programs on a regular basis for the private and public sector within the CFWMA. The Park County Weed and Pest Control District will work with the Forest Service to educated both the temporary and permanent employees on noxious weed iden tification and survey methods.

8. Biological control will be initiated and monitored throughout the CFWMA. Emphasis will be placed on biological control agents that adversely affect $C$ anada thistle and other weeds which are widespread and prevalent throughout the CFWMA. The University of Wyoming and Montana State University will be the lead agencies in biological control.

9. The first priority will be all trailheads and other disturbed sites with vehicle access. Chemical treatments will start at Colter Pass and continue west along the Beartooth Highway to Twin Lakes Scenic Vista near the summit of the Beartooth Range. Additional treatment will start at the junction of the Beartooth Highway and Chief Joseph Scenic Highway and continue over Dead Indian Pass to the Forest Service boundary and will include those areas associated with the Sunlight Creek Road. Treatment methods for this portion will consist of a truck mounted spray unit with hand held nozzles and two operators per unit.

10. The second priority will be areas such as subdivisions and seasonal cabins. The weed districts will be responsible for enforcing weed control on private land. The cost of treatment will be the responsibility of the landowner but the weed districts can use any cost share program they wish to help defray the expenses. Treatment methods will be left to the discretion of the landowner and the weed 


\section{Appendix 11}

district supervisor.

11. The third priority will be along heavily used access trails. Specific trails will be identified by Forest Service personnel during the first months of the summer and incorporated into this plan. Method of treatment for this portion of the program will consist of backpack or horse mounted units.

F. Develop and maintain an inventory

If additional funds exist, the balance will be used to survey and map areas of suspected infestation. These areas will include wetlands, regions of intense livestock grazing, and areas of intensified concentration of wildlife. Mapping of these areas will conform with the recommendations in Section $V$.

G. Develop and maintain a reporting system

A meeting of the involved agencies shall be held annually, sometime during the first three months of the calendar year, to develop and modify the action plan. Such action plan shall be attached to management plan and shall be come an intricate part of this document. 


\section{Appendix 12}

\section{Guidelines for a Safety Plan}

I. General All pesticide users must comply with 29 CFR 1910.1200, (OSHA's Hazard CommuGuidelines nication Standard). A Material Safety Data Sheet (MSDS) shall be obtained with each type of pesticide ordered. Pesticide applicators shall receive training on how to read the MSDS and be briefed on the information relating to the particular pesticide they use. The user must refer to each MSDS for specific information regarding first aid, transportation, storage and handling, disposal, and emergency actions. All users must comply with their individual agency standards regarding safety plans.

II. First Aid First aid involving chemical exposure should be incorporated into the WMA training and education courses. Personnel involved in all WMA projects should know the name, address, and telephone number of physicians and hospitals where treatment and information can be obtained. Post this information on any facilities where weed management activities occur.

A. First aid equipment should include a radio, an adequate first aid kit, a sprayer protection kit, a portable eye wash, and spill safety kit.

B. Emergency action steps necessary in the event of accidental poisoning:

1. Move the individual away from the pesticide and remove contaminated clothing. Wash the pesticide off skin.

2. If the individual is not breathing, or breathing is weak, initiate first aid (refer to label instructions).

3. Notify a physician of the pesticide involved. Administer antidote if advised by physician. Keep patient warm, quiet, and calm.

4. If appropriate, take the individual to the hospital. Have a copy of the pesticide label.

C. Poison Control Centers

1. In the case of any suspected poisoning accident, call the nearest Poison Control Center at once.

2. Poison Control Centers also provide treatment for poisoning.

\section{The Denver Poison Control Center number is}

$800.332 .30 \% 3$

D. General first aid procedures for various types of exposure:

1. Pesticide on skin: Immediately remove contaminated clothing and wash the affected area thoroughly with soap and water.

2. Pesticides taken orally: Read label and follow instructions. Consult physician immediately.

3. Pesticides in the eyes: Hold the eye(s) open and flush with a gentle stream of water for 15 minutes.

4. Pesticide burns: Remove contaminated clothing, wash skin 


\section{Appendix 12}

with large amounts of water, and cover with loose cloth. Treat for shock (see below). Do not treat with ointment or greases.

5. Pesticides inhaled: Move individual to fresh air, loosen clothing, and administer artificial respiration if breathing has stopped. Treat for shock (see below). If individual is in an enclosed space, do not enter the area without respiratory equipment.

E. Shock:

Sometimes poisoning victims go into shock. If untreated or ignored the victim can die from shock even if the poisoning injuries would not be fatal.

1. Shock symptoms

a. Skin is pale, moist, cold, and clammy.

b. The eyes are vacant and lackluster with dilated pupils.

c. Breathing is shallow and irregular.

d. Victim may be unconscious or in a faint.

2. Treatment of Shock

a. Unless the individual is vomiting, keep the victim flat on their back with legs up 1- to 1-1/2 feet above their head.

b. Keep victim warm enough to prevent shivering. Do not overheat.

c. If the victim is conscious and has not swallowed any poison, give small amounts of water or a dilute salt solution ( $1 / 2$ teaspoon table salt to $1 \mathrm{qt}$. of water). Give as often as the victim will accept it.

d. Keep victim quiet and reassure often.

e. Never try to give anything by mouth to an unconscious victim.

III. Transport-A. ing Pesticides
Carry pesticides in the cargo area of the vehicle, never in the passenger compartment.

B. Ensure that no container leaks develop, that no container is punctured or ruptured, that no lids or caps are loosened, and paper containers are kept dry.

C. Take special precautions while loading and stacking pesticide containers on a vehicle. Containers should be secured down, so that none can fall or roll about due to vehicle movement.

D. Containers must never be transported while open. Partially used containers must be securely resealed prior to movement.

E. After transport, inspect all pesticide containers for damage and leaks. Examine the vehicle carefully for contamination.

F. Generally, trucks with wooden platforms should not be used since documentation will probably require replacement of the planking.

G. The vehicle should carry herbicides only - never a mixed load. Irucks used to transport herbicides must never be used to transport food, 


\section{Appendix 12}

clothing, beverages, household goods, animal feeds, or similar commodities without prior decontamination.

IV. Storage and $A$
Handlling
A. General Safety Guidelines

Follow these guidelines to minimize spills and accidental contamination and allow better response in the case of fire.

1. Store all pesticides in a secure storage room which is kept locked at all times except when in use. Storage in the field during operations may require a full-time watchman.

2. Use locked storage on all vehicles used in pest control operations and transport of materials.

3. Label all materials in such a manner that the contents of all containers are plainly visible.

4. Keep chemicals separated by type to prevent cross-contamination.

5. Do not use obsolete or unsatisfactory materials and equipment.

6. Permit no smoking or eating in the storage area and post area with signs to that effect.

7. Identify pesticide storage area with prominent waterproof signs over each entrance (including windows) and on all sides of building. Post a llst of chemicals on the outside of building, along with storage plan.

8. Inform police, fire department, and medical officials in writing of the location and layout of the storage areas, types of materials stored, and hazards involved. Provide fire chief with telephone numbers of those personnel responsible for storage. Fire companies should map the locations of pesticide chemical storage in their respective areas. Pesticide Fires: Prevention, Control and Cleanup is available from AFPMB, Washington, D.C.

9. Inform nearest physician and hospital of potential hazards, and ensure that medical personnel know how to treat for pesticide exposure. Ensure that the Clinical Handbook on Economic Poisons is available. Obtain copy from HHS, Communicable Disease Center, Office of Pesticides, Atlanta, Georgia 30333.

10. Obtain desirable fire-fighting equipment (extinguishers) and have all employees familiarize themselves with its operation. Be sure the equipment works properly.

11. Keep pesticide containers, particularly glass, away from windows and sunlight so they will not be subject to heat and ignition.

12. Keep combustibles away from steam lines and heat. Read label for information on flammability and store accordingly.

13. Dispose of unlabelled pesticides. Treat them as highly toxic.

14. Keep a quantity of absorbent material on hand for detoxification. 


\section{Appendix 12}

15. In the event of container leakage, immediately make drop pans available until repackaging is completed.

16. Never use milk or beverage bottles, or any type of food containers, for storage of toxic chemicals.

17. Clean up spilled chemicals immediately.

B. Handling of Pesticides

1. It is extremely important to follow label requirements pertaining to the use of safety equipment and clothing. Each job should be assessed for hazard - there may be occasions when common sense requires additional precautions to be taken even though not required by law.

2. Pesticide poisoning of applicators or those associated with the application usually occurs from absorption through the skin. To avoid pesticides from coming into contact with the skin, it is recommended that the following minimum requirements apply to

all pesticide use, regardless of the hazard category (label specifications may require more stringent measures):

a. Coveralls that should cover the entire body from wrists to ankles should be worn at all times during handling, mixing, flagging, or application operations. Pant legs and sleeves should be worn outside of boots and gloves.

b. Gloves and Boots should be made of unlined rubber or neoprene material. In some cases the label will specifically state which type of gloves and boots to be used. Check the gloves for leaks prior to use, by filling with water and squeezing the glove. Boots should be of the type that has support around the ankles to prevent injury when walking in rough terrain.

c. Goggle/Face Shield - Goggles should be worn when pouring or mixing concentrates. Goggles should be the type that are non-fogging. Face shields should be made of clear plastic and be attached to the hat so they can be raised and lowered. Do not use eye protection with a headband that can absorb pesticide.

d. Hats should be made of a liquid-proof, washable plastic with plastic sweatband. These hats should be worn during pesticide application, flagging, and mixing opera. tions. Hats with leather sweatbands should not be worn.

e. Respiratory Device - The respirator must properly fit the face, so that air leakage does not occur. The user must be clean shaven. Use only equipment that is approved by the National Institute for Occupational 


\section{Appendix 12}

Safety and Health or the Mining Enforcement and Safety Administration. The user must be instructed in its use.

C. The following additional guidelines should be followed when handling pesticides:

1. Handle full barrels of chemicals with care to avoid personal injury - use barrel rolls if applicable.

2. To minimize inhalation, handle all pesticides in well-ventilated areas only.

3. Immediately wash any contamination off the skin, with detergent and water. Frequent washing of the skin during and after pesticide application is as important as protective clothing.

V. Container Pesticide containers retain a small amount of pesticide even after being rinsed.

Disposal Therefore, the disposal of all pesticide containers must comply with Federal, State, and local laws. County extension agents, County weed supervisors, or State regulatory officials should be familiar with the local requirements.

1. Account for every used container and never allow unrestricted use by individuals.

2. All liquid containers must be rinsed at least three times prior to disposal. Spray the rinse water on to the treatment area.

3. Disposal of containers must be made in accordance to local and state regulations. Some landfills refuse pesticide containers.

It is extremely important that pesticide project plans include a carefully thought

VI. Emergency

Action out course of action which addresses emergency situations. Without prior planning, unnecessary delays and additional damage or injury could occur as a result of a spill or fire. Everyone involved in the project should be aware of the procedures and their responsibilities for implementation.

Notes: 


\section{Appendix 13}

\section{Testing Programs, Contract Clauses, and Closure Statements}

I. Sample
Professional
Personal
Services
Contract

This Professional Personal Services Contract made and entered this 1 day of luly 1985, by and between the Montana Department of Fish, Wildlife, and Parks from its Helena office, hereinafter referred to as department, and Cascade County Weed Control of Cascade County, hereinafter referred to as contractor.

WHEREAS, department has need of the personal services of contractor in the profession of Weed Control, and contractor desires to provides those services to department.

Now, THEREFORE, in consideration for the terms, conditions, and promises as hereinafter set forth, department and contractor agree as follows:

1. Purpose. The purpose of this contract is to provide department with the professional personal services of contractor in order to do the following: Spray leafy spurge on Department lands on Smith River (BLM in-lieu lands.)

2. Contractors' duties. In order to fulfill the purpose of this contract, contractor agrees and promises to carry out the following duties.

Spray leafy spurge on Department lands on Smith River and such other related tasks as necessary to fulfill this contract.

3. Compensation. Department agrees and promises to pay to contractor compensation as follows: $\$ 7.00 / \mathrm{Hr}$. Labor $-\$ 6.00 / \mathrm{Hr}$ Truck + Chemical per diem prorated with other accounts. Maximum compensation not to exceed $\$ 400.00$.

Payment for partial performance of any services under this contract may not be made prior to approval of that performance by the department liaison. Final payment under his contract may not be made until all services required under his contract and all applicable terms of the contract have been met. Each billing by contractor shall include the following wording and appropriate party shall sign accordingly: been paid therefor."

"I certify that the foregoing statement is true and accurate and that I have not

\section{(Contractor)}

\section{Revised}

April 1984

4.

Effective date and performance schedule. The term of this contract is from July 1. 1985 through Sept. 1, 1985.

5. Liaison. Department designates Dave Todd as liaison for contractor under this agreement. Contractor agrees to make all official contacts with department with this designee, or such other person as the designee appoints.

6. Department assistance. Department agrees and promises to provide assistance to contractor as follows: Provide maps as necessary.

7. Ownership and publication of materials. Unless specifically set forth in this item, department retains ownership for all purposes of the working papers, working products, and end products resultant from partial or full performance under this contract. Contractor agrees and promises to have all information concerning activities under his contract approved by the designated liaison prior to release of that information.

8. Independent contractor. This contract is with contractor as an independent contract and does not establish an employer-employee relationship with contractor or any person employed by him for any purpose. In this regard, contractor agrees to pay all state, federal, or local taxes, fees, or other assessments related to employment of himself or any person or individual employed by him as necessary in fulfillment of this contract.

8a. The contractor agrees to obtain in full force and effect, without any 


\section{Appendix 13}

periods of lapse, worker's compensation insurance on all employees of the contractors. This insurance coverage shall be continuous during the entire term of this contract. As an alternative to maintaining effective worker's compensation insurance coverage on all employees of the contractor, these members may be certified as independent contractors provided that criteria for such election described in 39-71-401, MCA, and the Administrative Rules of Montana, are met.

8b. Student intern. This contract is with contractor as a student intern. The school program sponsored and required of contractor by the educational institution he is attending is N/A. Contractor hereby states he is neither an independent contractor nor an employee of the Montana Department of Fish, Wildlife and parks, but rather a student of _ N/A (applicable educational institution)

9. Special conditions. Contractor agrees and promises to perform the special conditions under his agreement as follows:

Use caution when spraying along water's edge

10. Records by contractor. Contractor agrees and promises to keep and maintain reasonable records of activities performed under this contract.

11. Access to records. As required by law, contractor agrees to permit access to those contractor's records as may be necessary for legislative post-audit and analysis purposes in determining compliance with the terms of this contract. This contract shall automatically terminate upon refusal of contractor to allow access to records necessary to carry out the legislative post-audit and analysis functions set forth in Title 5, Chapters $12 \& 13, \mathrm{MCA}$.

12. Termination and default. This contract may be terminated by notice in writing to the opposite party at its address as set forth herein at least days prior to the effective date of termination. Upon default by either department or contractor, the nondefaulting party may terminate this contract as set forth in this item. If default is remedied prior to the effective date of termination, the nondefaulting party may elect not to terminate this contract. Upon termination, department agrees and promises to pay contractor for work performed up to and including the termination date, and contractor agrees and promises to return all materials supplied by department except those used in performance of this contract as well as working papers, working products, and end products resulting from this agreement.

13. Venue. Department and contractor agree that venue for any court action arising under this agreement shall be in the First Judicial District in and for Lewis and Clark County, Montana. Further, department and contractor agree that this contract shall be interpreted according to the laws of Montana.

14. Assignment. Department and contractor agree that as this contract is for the personal services of contractor, this contract is not assignable, may not be transferred, nor may a subcontract be let hereunder unless both parties agree in writing prior to any such action.

15. Entire agreement-modification. This writing contains the entire agreement between department and contractor on the subject matter of this contract; statements, promises, or inducements made by either party or agents of either party, which are not contained in this agreement, are not valid or binding. No modification, enlargement, or alteration of this contract is valid or binding except upon written agreement signed by all parties to this contract.

16. Bonds. The department, or any subdivision thereof (board, council, commission or trustee), or body acting for the department, may require a bond to insure the 1) faithful performance of all the provisions of the agreement; 2) full payment of all laborers or subcontractors; 3) full payment to all persons supplying goods, services, materials or supplies to complete the work herein prescribed. It is hereby agreed that the contractor, upon adequate and due notice from the department prior to consummation of this agreement, will supply sufficient 


\section{Appendix 13}

bond, provided by a reputable and established surety company or other method approved by the State of Montana, the terms of which will be established by the department.

A copy of said bond shall be filed with the County Clerk and Recorder for Lewis and Clark County, and other counties where such work is performed.

17. Equal Employment Opportunity. Pursuant to Sections 49-2-303 and 49-3-207, Montana Code Annotated, no part of this agreement shall be performed in a manner which discriminates against any person on the basis of race, color, religion, creed, political ideas, sex, age, marital status, physical or mental handicap, or natural origin by the persons performing the agreement. Any hiring shall be on the basis of merit and qualifications directly related to the requirements of the particular position being filled.

18. Fair Labor Standards. The contractor agrees to comply with all federal and state wage and hour rules, statutes and regulations, and warrants that all applicable federal and state fair labor standards provisions will be complied with, both by the contractor, in the event the sub-contracted services to fulfill the terms and conditions of the agreement are agreed upon by the department and the contractor.

19. Inability to Fulfill Contract. It is understood that contractor will notify the liaison of the department immediately upon determination that any malady or occurrence has taken place which would, in any way, affect or alter the duties, responsibilities, authorities, relationships or ability of the contractor to fulfill the provisions of this agreement in a timely manner and as prescribed herein.

20. Execution. Each party has full power and authority to enter into and perform this agreement, and the person signing this agreement on behalf of each party further acknowledges that he has read this agreement, understands it and agrees to be bound by it.

IN WITNESS WHEREOF, the undersigned parties to this contract caused this contract to be entered into on the date first above written.

CONTRACTOR

By

$405 / A$
DEPT. OF FISH, WILDLIFE \& PARKS

By

Approved for legal consent: 


\section{Appendix 13}

\section{Sample \\ Disturbed Site \\ Rehabilitation \\ Contract}

III. Sample
Closure Order

\section{Protection of Disturbed Areas from Establishment of Noxious Weeds.}

To protect disturbed areas such as, but not limited to, landings, temporary roads, and loading ramps from establishment of noxious weeds the purchaser shall, when directed in writing by Forest Service, revegetate those areas where purchaser's operations have exposed the mineral soil.

Revegetation shall be done by seeding with grass or other desirable herbaceous seed. All seed used shall be certified and approved in advance by Forest Service.

Unless agreed to in writing, seeding shall be done in the early spring or fall during weather and moisture conditions favorable for quick germination and growth of the seed. Seeding shall be completed within 6 months of the last disturbance activity scheduled by the purchaser on the disturbed areas and before the germination of noxious weed seedlings.

Seeding shall be spread evenly at the rate of pounds per acre and the seed mixture shall consist of to seeding, purchaser shall apply pounds per acre of fertilizer. Percentages of nitrogen, phosphate, and potassium shall not be less than

Purchaser may, under B4.225, deposit sufficient funds to cover the cost of seeding. The rate of deposit for seeding shall be $1 /$ dollars $(\$$ ) per $M$ board feet) $\underline{2} /$, (other, specify) $\underline{3} /$ or equivalent for (Live-Dead) $4 /$ material meeting utilization standards and reported cut.

\section{Public Notice \\ ORDER ESTABLISHINC PROHIBITIONS IN AREAS OF THE SHOSHONE NATIONAL FOREST}

USDA - Forest Service

Shoshone National Forest

P.O. Box 2140

Cody, WY 82414

Telephone: (307) 527-6241

WASHAKIE WILDERNESS ORDER

By virtue of the authority vested in me under the Regulations of the Secretary of Agriculture, 36 CFR 261.50 (a) \& (b), the following acts are prohibited:

1. Grazing transportation livestock on sites posted closed to grazing [36 CFR $261.57(\mathrm{e})]$.

2. Possessing or transporting other than processed supplemental feed for livestock [36 CFR $261.58(\mathrm{t})$ ].

This order is posted in accordance with 36 CFR 261.51.

THIS ORDER SUPERSEDES AND RESCINDS STEPHEN P. MEALEY'S ORDER OF JUNE 21, 1984. DONE AT CODY, WYOMING THIS 3OTH DAY OF MAY, 1985.

\section{Stephen P. Mealey, Forest Supervisor}

Violations of this prohibition and the other regulations found in 36 CFR 261.3 through 261.21 are punishable by a fine of not more than $\mathbf{\$ 5 0 0}$ or imprisonment for not more than six months or both (16 USC 551). 


\section{Appendix 13}

\author{
IV. Sample \\ Inter-Agency \\ Quarantine \\ Agreement
}

\section{State of Wyoming \\ Memorandum of Understanding}

A. PARTIES: This Agreement is made between the Wyoming Highway Patrol (WHP), Wyoming Department of Agriculture (WDA), Park County and Teton County Weed and Pest Control (District).

B. AUTHORITY: W.S. 11-2-202, 11-5-116, 11-5-118, 37-8-301 and 24-12-103.

C. PURPOSE: The parties desire to cooperate in the enforcement of quarantines established pursuant to W.S. 11-5-116.

D. SERVICES BY THE WHP:

1. The WHP shall provide assistance to the WDA and the District in the implementation of the quarantine by providing inspection of vehicles transporting agronomic crops and/or farm products into and within Park County or Teton County.

2. The WHP shall periodically check vehicles transporting agronomic crops and/or farm products (hay \& straw) into and within Teton County and request proof of Transit Certificate (WDA-70).

3. The WHP shall periodically check vehicles transporting agronomic crops and/or farm products into Park County, and request proof of Transit Certificate (WDA70). Agronomic crops and/or farm products being transported into or within Park County requires either a Quarantine Release (WDA-113) or Transit Certificate (WDA-70).

4. Any driver failing to provide proof of certification shall be advised to: 1) return the cargo to its point of origin, or 2) change the destination of the cargo to a place outside of Park County or Teton County. The WHP at its discretion will take appropriate enforcement action.

5. Advise the individual of their right to a consultation within twenty-four (24) hours before the district board or its designated agent or legal counsel, for the purpose of providing proof of certification. In the event the individual exercises the right to a consultation, the cargo shall be moved to a port of entry or other location designated by the WHP or the District until said consultation has been held, and the cargo is released. Any person violating any provision of the quarantine may be subject to a fine not to exceed $\$ 100$ pursuant to W.S. 11-5117.

E. SERVICES BY THE DISTRICT:

1. Provide personnel to inspect fields for certification.

2. Provide assistance upon request to WHP to answer certification questions.

3. Pay for services rendered as agreed upon between affected District and the WHP.

4. If requested, grant the individual a consultation within twenty-four (24) hours. [See D (5) above regarding temporary storage of cargo.] Any person violating any provision of the quarantine may be subject to a fine not to exceed $\$ 100$ pursuant to W.S. 11-5-117.

F. SERVICES BY THE WDA:

1. Provide certificate of inspection (WDA-69) \& transit certificate forms (WDA-70).

2. Provide assistance upon request to WHP to answer certification questions.

3. Provide assistance upon request to the District.

4. Provide a procedure manual for the enforcement of quarantines.

G. DURATION OF THIS AGREEMENT:

1. This agreement shall become effective upon signing by all parties and shall remain in effect until terminated by written notice of one of the parties.

2. This agreement may be amended by written mutual agreement of the parties. H. COMPLIANCE WITH LAWS:

In performing this contract, all parties agree to comply with all applicable state, federal, and local laws, rules, and regulations.

I. SOVEREIGN IMMUNITY:

The State and District reserve all claims it may have to sovereign immunity from events arising out of this agreement. 


\section{Appendix 13}

\section{Sample County Weed Management Agreement}

\section{WEED CONTROL PLAN \\ (Project Name - County)}

The Department of State Lands, Abandoned Mine Reclamation (AMR) Bureau hereby submits this Weed Control Plan to the County Weed Control Board as required by the Montana County Noxious Weed Management Act. Rule 7-22-2121, New Section C (3) (a) states, "The person or agency disturbing the land shall submit to the board a written plan specifying the methods to be used to accomplish revegetation. The plan must describe the time and method of seeding, fertilization practices, recommended plant species, use of weed-free seed, and weed management procedures to be used."

The attached Invitation For Bid package, covers most of the above requirement under the following sections: (1) Section IV, Special Provisions, Subsection 4.30, Fertilizing, Seeding, and Mulching; and (2) Section V, Technical Specifications, Subsection 5.00, Seed and Fertilizer.

Upon completion of the Project the Abandoned Mine Reclamation Bureau will continue to monitor the site biannually for any further abandoned mine hazards and any growth of noxious weeds. If any noxious weeds listed by the County Weed District appear on the reclamation site, the County Weed Supervisor will be notified immediately.

The most effective method of control will be implemented according to the District's noxious weed program. The AMR Program assumes responsibility for weed control on all AMR sites during reclamation construction and for two years after the date of reclamation completion. After two years, the weed control responsibility reverts back to the deeded landowner.

The Weed Control Plan for the Abandoned Mine Reclamation Project is officially approved and in effect until two years after the completion of reclamation construction when executed by the following officials.

Richard L. Juntunen, Chief

Date

Abandoned Mine Reclamation Bureau

Department of State Lands

Chairman

County Weed Control Board

Date

County Weed Control Board

Supervisor County Weed District

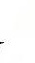




\section{Appendix 13}

MCA. Upon written request of Department, District may conduct management and control measures neces sary for compliance with Title 7, Chapter 22, Part 21, MCA, or state lands and on easements held by the Department.

B. For State Lands Subject to an Easement - District shall treat all easements across state lands as the private land of the easement holder.

C. For State Lands Subject to a Land Use Authorization -

1. Request by District for Voluntary Compliance: When the District has received a complaint or has other reason to believe that noxious weeds are present on state lands subject to a land use authorization, such as a lease, license sale contract, timber sale contract, District shall notify the holder of the land use authorization, inspect as necessary, seek voluntary compliance, as provided in 7-22-2123, by the holder of the land use authorization.

2. Enforcement by District - If noxious weeds are present on state lands subject to a land use authorization and also present on private lands owned or controlled by the holder of the state land use authorization, the District shall include the state lands in whatever enforcement action it takes to remedy the weed problem on the private lands.

3. Department Assistance to District - If noxious weeds are present on state lands subject to a land use authorization but are not present on the private lands owned or controlled by the holder of that state land use authorization, and the holder of the state land refuses to voluntarily comply after District action under C. 1., District shall then require compliance through administration of its land use authorization.

II. Other Responsibilities of Department
A. Department shall reimburse District for all weed management and control measures conducted pursuant to $I$. A. above. Department may not request District to conduct weed management and control unless it has money appropriated by the Montana Legislature for that purpose.

B. Department shall notify the District of any noxious weed infestation it observes on state lands or on easements held by Department within District.

C. Upon request of District, Department shall, whenever possible, furnish information and assistance to develop District's noxious weed management plan.

III. Administration of Agreement

A. Each party to this agreement agrees to hold the other party free and harmless of and from all liability arising out of, or occasioned by, the negligence of that other party, its agents, officers, and employees in the conduct of control and management activities pursuant to this agreement.

B. This agreement is effective upon signature by both parties and remains in effect until no longer authorized by law or until terminated by either party on 30 days written notice.

C. Department's obligation under this Cooperative Agreement are contingent upon appropriation of funds by the Montana Legislature.

Weed Management District

By:

Chairman

DEPARTMENT OF STATE LANDS

By:

Dennis Hemmer, Commissioner Date 


\section{Appendix 13}

\section{Sample} Source of Material Contract

\section{Source of Supply and Quality Requirements.}

All material sources shall meet weed-free requirements set forth in the CYA Certification Standards For Feeds (livestock and wildlife), Mulches, Bedding, and Re-seeding Materials. The Contractor shall notify the Engineer of the source (s) proposed for use at least 1 month before beginning operations or starting crushing. The source(s) will be Investigated for "weeds of concern" during the period. If weeds of concern are present, the investigator will determine if the upper portion of the source is to be stripped or the weeds sprayed with a herbicide. When spraying is required, the spray shall be applied by a licensed operator in accordance with the regulations of the applicable state where the source is located. An agronomist's certification that the source(s) is free from "weeds of concern" may be substituted for the above requirements.

Material Source Management.

If Material Source

is used, the following provisions shall apply:

* The Contractor's activities shall be restricted to the areas designated on the Development and Reclamation Plan (DRP).

* $\quad$ Area $A$ is reserved for this project and has been previously stripped and partially developed. The excavated portion of the area is filled with water. The area shall be developed from west to east. The depth of the excavation may vary with material availability. 


\section{Appendix 14}

\section{Weed Science Society of America Accepted Names and Weed Codes}

Common Name
Alfalfa
Austrian fieldcress
Austrian pea weed
Buffalobur
Camelthorn
Canada thistle
Common burdock
Common crupina
Dalmatian toadflax
Downy brome
Diffuse knapweed
Dyers woad
Field Bindweed
Goatweed (St. Johnswort)
Globepodded hoarycress
Henbane
Hoary cress (Whitetop)
Houndstongue
Jointed goatgrass
Leafy spurge
Loosestrife
Musk thistle
Ox-eye daisy
Perennial pepperweed
Perennial sowthistle
Plumeless thistle
Poison hemlock
Puncturevine
Quackgrass
Rush skeletonweed
Russian knapweed
Scotch thistle
Showy milkweed
Silver-leaf nightshade
Skeletonleaf bursage
Smooth brome
Spotted knapweed
Syrian bean caper
Tansy aster (Common)

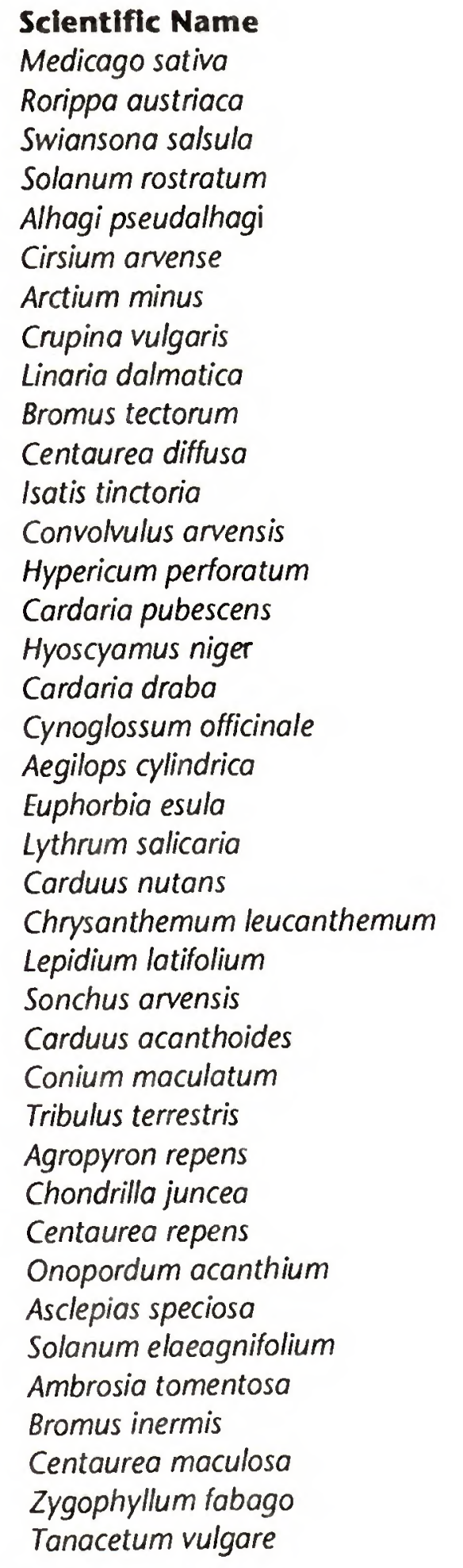

Code

MEDSA

RORAU

SWASA

SOLCU

ALHPS

CIRAR

ARFMI

CJNVU

LINDA

BROTE

CENDI

ISATI

CONAR

HYPPE

CADPU

HSYNI

CADDR

CWWOF

AEGCY

EPHES

LYTSA

CRUNU

CHYLE

LEPLA

SONAR

CRUAC

COIMA

TRBTE

AGRRE

CHOJU

CENRE

ONRAC

ASCSP

SOLEL

FRSTO

BROIN

CENMA

ZYGFA

CHYU 


\section{Appendix 14}

Tansy mustard
Tansy ragwort
Timothy
Wild carrot
Woolly (common) mullein
Yellow starthistle
Yellow sweetclover
Yellow toadflax

Descurainia pinnata

Senecio jacobaea

Phleum pratense

Daucus caroto

Verbascum thapsus

Centaurea solstitialis

Melilotus officinalis

Linaria vulgaris
DESPI

SENJA

PHLPR

DAUCA

VESTH

CENSO

MEUOF

LINVU 


\section{Appendix 15}

\section{Sources of Information}

I. Reference Personnel
A. Greater Yellowstone CoordInating Committee

Team Leader

Greater Yellowstone Coordinating Committee

Box 2556

Billings, MT 59103

406-657-6361

B. National Park Service

(1) Regional Director

Rocky Mountain Region

National Park Service

P.O. Box 25287

Denver, CO 80225-02871

(3) Superintendent

Yellowstone National Park

P.O. Box 168

Yellowstone National Park, WY 82190-0168

307-344-7381

C. USDA Forest Service

(1) Regional Forester

USDA Forest Service

Intermountain Region

Federal Building

324 N. 25th St.

Ogden, UT 84401

801-625-5352

(3) Regional Forester

USDA Forest Service

Northern Region

Federal Building

P.O. Box 7669

Missoula, MT 59807

406-329-3511:

(5) Forest Supervisor

Bridger Teton National Forest

340 N. Cache

P.O. Box 1888

Jackson, WY 83001

307-773-2752
(2) Superintendent

Grand Teton National Park

P.O. Drawer 170

Moose, WY 83012

307-733-2880
(2) Regional Forester

USDA Forest Service

Rocky Mountain Region

P.O. Box 25127

Lakewood, CO 80225

303-236-9431

(4) Forest Supervisor

Beaverhead National Forest

610 N. Montana

Dillon, MT 59725

406-683-3900

(6) Forest Supervisor

Custer National Forest

Box 2556

Billings, MT 59103

406-657-6361 


\section{Appendix 15}

(7) Forest Supervisor

Shoshone National Forest

Box 2140

Cody, WY 82414

307-527-6241

(9) Forest Supervisor

Targhee National Forest

P.O. Box 208

St. Anthony, ID 83445

208-624-3151

D. Bureau of Land Management

(1) State Director

BLM, Idaho State Office

3380 Americana Terrace

Boise, ID 83706

208-334-1401

(3) State Director

BLM, Wyoming State Office

2515 Warren Avenue

P.O. Box 1828

Cheyenne, WY 82003

307-772-2326

(5) District Manager

BLM, Butte District Office

106 N. Parkmont

P.O. Box 3388

Butte, MT 59702

406-494-50591

(7) District Manager

BLM, Rock Springs District Office

P.O. Box 1869

Highway 191 North

Rock Springs, WY 82901

307-382-5350
(8) Forest Supervisor

Gallatin National Forest

P.O. Box 130

Bozeman, MT 59715

406-587-6701

(10) Forest Supervisor

Caribou National Forest

Federal Building

250 S. Forest Ave, \#294

Pocatello, ID 83201

208-236-7500

(2) State Director

BLM, Montana State Office

222 North 32 nd St.

P.O. Box 36800

Billings, MT 59107

406-255-2904

(4) District Manager

BLM, Idaho Falls District Office

940 Lincoln Road

Idaho Falls, ID 83401

208-529-1020

(6) District Manager

BLM, Miles City District Office

West of Miles City

P.O. Box 940

Miles City, MT 59301

406-232-4331

(8) District Manager

BLM, Worland District Office

P.O. Box 119

101 South 23 St.

Worland, WY 82401

307-347-9871 


\section{Appendix 15}

\section{E. State Department of Agriculture}

(1) ID State Weed Coordinator Idaho Dept of Agriculture 120 Klotz Lane Boise, ID 83702 208-334-2986

(2) MT State Weed Coordinator Montana Dept of Agriculture Capitol Station

Agriculture/Livestock Building Helena, MT 59620

406-444-2944

(3) WY Weed and Pest Coordinator Wyoming Dept of Agriculture 2219 Carey Ave.

Cheyenne, WY 82003

307-777-6585

\section{F. County Weed Supervisors}

(1) Idaho

(a) Bonneville Countty Weed Supv 605 Capital Ave Idaho Falls, ID 83805

208-267-5341

(c) Fremont County Weed Supv St. Anthony, ID 83445 208-624-3102

(b) Caribou County Weed Supv Box 638.

Soda Springs, ID 83276

208-547-4483

(d) Jefferson County Weed Supv Courthouse, Room 34

Rigby, ID 83442

208-745-6984

(e) Madison County Weed Supv Box 5801

Rexburg, ID 83440 208-356-3191

(f) Teton County Weed Supv Courthouse Driggs, ID 83422 208-787-2959

(2) Montana

(a) Beaverhead County Weed Supv 2 South Pacific CL 12 Dillon, MT 59725 406-683-4923

(b) Carbon County Weed Supv Box 215 Joliet, MT 59041 406-962-3490

(c) Gallatin County Weed Supv $\mathrm{Rm}$ 304, Courthouse Bozeman, MT 59715 406-585-1359

(d) Madison County Weed Supv Box 278

Virginia City, MT 59755 406-843-5392

(e) Park County Weed Supv $414 \mathrm{E}$. Callender Livingston, MT 59047 406-222-6120

(f) Stillwater County Weed Supv Box 344 Absarokee, MT 59001 406-328-4165 


\section{Appendix 15}

(g) Sweet Grass County Weed Supv

Box 1033

Big Timber, MT 59011

406-932-4718

(3) Wyoming Weed \& Pest (W \& P)

(a) Fremont County W \& P Supv Courthouse, N. 2nd St.

Lander, WY 82520

207-332-2848

(c) Lincoln County W \& P Supv

P.O. Box 1117

Afton, WY 83110

307-886-3394

(b) Hot Spgs County W \& P

Supv - P.O. Box 543

Thermopolis, WY 82443

307-864-2278

(d) Park County W \& P Supv

P.O. Box 626

Powell, WY 82435

307-754-4521

(e) Sweetwater County W \& P Supv (f) Teton County W \& P Supv

P.O. Box 73

Farson, WY 82932

307-273-9683

P.O. Box 1852

Jackson, WY 83001

307-733-8419

\section{G. Weed Scientists and Entomologists}

(1) Dept of Ent., Plant \& Soil Science

College of Agriculture

University of Idaho

Moscow, ID 83843

(2) Dept of Plant \& Soil Sciences

College of Agriculture

Montana State University

Bozeman, MT 59717

(3) Dept of Entomology

College of Agriculture

Montana State University

Bozeman, MT 59717

(4) Dept of Plant \& Soil Sciences

College of Agriculture

University of Wyoming

Laramie, WY 82071

(5) Dept of Entomology

College of Agriculture

University of Wyoming

Laramie, WY 82071

(6) USDA, Ag Research Service

Rangeland Weeds Laboratory

Culbertson Hall

Montana State University

Bozeman, MT 59717

(7) USDA, APHIS, PPQ

Bio-Control Facility

Forestry Sciences Laboratory

Montana State University

Bozeman, MT 59717 


\section{Appendix 15}

H. USDA, Soll Conservation Service

(1) State Conservationist

Soil Conservation Service

801 State Capitol Blvd.

Boise, ID 83702

(3) State Conservationist

Soil Conservation Service

Federal Office Building

100 East "B" St., Room 3124

Casper, WY 82601
(2) State Conservationist Soil Conservation Service Federal Building, Room 443 10 East Babcock St. Bozeman, MT 59715-4704

\section{Greater Yellowstone Association of Conservation Districts}

Executive Director

P.O. Box 176

Bozeman, MT 59771

406-586-9333

Idaho

(1) Caribou Soil Conservation Dist.

159 East 2nd South \#4

Soda Springs, ID 83276

208-547-2558

(2) Clark Soil Conservation Dist.

263 East 4th North

Rexburg, ID 83440

208-522-5137

(3) East Side Soil \& Water Cons. Dist.

1120 Lincoln Road

Idaho Falls, ID 83401

208-522-5137

(4) Madison Soil \& Water Cons. Dist

263 East 4 th North

Rexburg, ID 83440

208-522-5137

(5) Teton Soil Conservation Dist.

P.O. Box 87

Driggs, ID 83422

208-354-2955

(6) Yellowstone Soil Cons. Dist.

315 East 5th North

St. Anthony, ID 83445

208-624-3341

Montana

(1) Beaverhead Conservation Dist.

117 South Idaho Street

P.O. Box 606

Dillon, MT 59725

406-683-6539

(2) Carbon Conservation Dist. 205 South Main Street

Drawer J

Joliet, MT 59041

406-962-3641

(3) Madison Conservation Dist.

219 Main Street

P.O. Box 606

Ennis, MT 59729

406-682-7289

(4) Park Conservation Dist.

Route, 62, Box 3197

Livingston, MT 59047

406-222-2899 


\section{Appendix 15}

(5) Ruby Valley Conservation Dist.

104 Poppleton Street

P.O. Box 295

Sheridan, MT 59749

406-842-5741

(7) Sweet Grass Conservation Dist.

P.O. Box 749

Highway 10 East

Big Timber, MT 59011

406-932-5160

Wyoming

(1) Big Sandy Conservation Dist.

P.O. Box 202

Farson, WY 82932

307-273-5531

(3) Dubois-Crowheart Cons. Dist.

P.O. Box 27

Dubois, WY 82513

307-455-2388

(5) Lincoln Conservation Dist.

110 Pine Street

Cokeville Town Hall, Rm 1

P.O. Box 98

Cokeville, Wr 83114

307-279-3256

(7) Popo Agie Conservation Dist.

177 North 3rd

Lander, WY 82520

307-332-3144

(9) Riverton Conservation Dist.

320 East Lincoln

Riverton, WY 82501

307-856-7524

(11) South Big Horn Cons. Dist. 444 Greybull Avenue Box 791

Greybull, WY 82426

307-765-2483
(6) Stillwater Conservation Dist.

130 South Pratten

P.O. Box 415

Columbus, MT 59019

406-322-5359

(2) Cody Conservation Dist.

4958 Powell Highway

Cody, WY 82414

307-527-7780

(4) Hot Springs Conservation Dist.

606 Amoretti

Thermopolis, WY 82443

307-864-3488

(6) Meeteetse Conservation Dist.

5423 State Highway 120

P.O. Box 528

Meeteetse, WY 82433

307-868-2431

(8) Powell-Clarks Fork Cons. Dist.

140 North Ferris

Powell, WY 82435

307-754-9301

(10) Shoshone Conservation Dist. 359 Nevada Avenue Lovell, WY 82431 307-548-7422

(12) Star Valley Conservation Dist. 338 Washington Street, \#14

P.O. Box 216

Afton, WY 83110

307-886-3018 


\section{Appendix 15}

(13) Sublette Conservation Dist. P.O. Box 36

Pinedale, WY 82941

307-367-2257
(14) Teton Conservation Dist.

125 East Pearl

P.O. Box $S$ Jackson, WY 83001

307-733-2110

(15) Washakie County Cons. Dist.

1700 Robertson

Worland, WV 82401

307-347-2212

\section{Informational \\ Publications Available \\ Pertaining to \\ Weed Identifi- cation and Control}

\section{TITLE}

A GUIDE TO SELECTED WEEDS OF OREGON

by: R.B. Hawkes, T.D. Whitson and

La Rea ). Dennis

Oregon Dept. of Agriculture in

Cooperation with Oregon State Univ.

1985

CHEMICAL CONTROL OF RANGE WEEDS

(Grasses-Forbs-Woody Plants)

Reproduced from USDA-USDI Publication

\section{AVAILABLE FROM}

Oregon State University

Bookstore

Corvallis, OR 97331

(503) $754-4323$

Montana Extension Service Extension Mailing Room

Pryor Hall - MSU

Bozeman, MT 59717

COMMON MONTANA RANGE PLANTS

MSU Range Science Club, 2nd Ed.

MSU Range Science Dept.

$\$ 13.50$

Robert R. Yaeger, Wayne C. Leininger,

and Donald $E$. Ryerson

CONTROL OF WEEDS \& WOODY PLANTS

Agricultural Ext. Service

ON RANGELANDS

by: R.W. Bovey, A.F. Wiese,

R.A. Evans, H.L. Morton

University of Minnesota

St. Paul, MN 55108

(612) 373.1615

H.P. Alley

June, 1984 AB-BU-2344

EASTERN WASHINGTON RANGE PLANTS EB 1302 Washington State Univ.

Ben F. Roche Jr. and Cindy Jo Talbot

Published November 1984

Cooperative Ext. Service $\$ 1.50$

FLORA OF THE GREAT PLAINS. 1986.

University Press of Kansas

The Great Plains Flora Association

Ronald L. McGregor, Coordinator

University Press of Kansas

Lawrence, KS 66045

$\$ 55.00$, plus $\$ 1.50$ postage 


\section{Appendix 15}

FLORA OF THE PACIFIC NORTHWEST, 1973

C. Leo Hitchcock \& Arthur Cronquist University of Washington Press
Montana State University Bookstore $\$ 42.75$

GILKEY'S WEEDS OF THE PACIFIC NORTHWEST Oregon State Univ. Press

by: La Rea J. Dennis

Library of Congress Catalog No. 80-82742

ISBN: 0-88246-039-0

HERBICIDE HANDBOOK OF THE WEED

SCIENCE SOCIETY OF AMERICA

5th Edition, 1983
Weed Science Soc. of America 309 West Clark Street

Champaign, II 61320
HERBICIDE MANUAL: A WATER RESOURCES

TECHNICAL PUBLICATION

First Edition, 1983

U.S. Department of Interior
Superintendent of Documents

U.S. Gov. Printing Office

Washington, D.C. 20402
HERBICIDE MANUAL FOR NONCROPLAND

WEEDS

by: R.S. Dunham

Issued March, 1965

Agricultural Handbook \# $269 \$ .50$
Superintendent of

Documents

U.S. Gov. Printing Office

Washington, D.C. 20402
HERBICIDES FOR MONTANA CROPS

Packet \# 13

$\$ 5.00$
Montana Extension Service

Extension Mailing Room

Pryor Hall - MSU

Bozeman, MT 59717

INTERMOUNTAIN FLORE: VASCULAR PLANTS

Available from bookstores

OF THE INTERMOUNTAIN WEST, USA - Vol. $6 \$ \$ 78.00$

The Monocotyledons. 1977

Arthur Cronquist, Arthur H. Holmgren,

Noel H. Holmgren, James Reveal,

Patricia K. Holmgren.

Published for the New York Botanical

Garden by Columbia University Press, New York.

KNAPWEED - ITS CAUSE, EFFECT AND

SPREAD IN MONTANA

Circular 307

April, 1983
Cooperative Extension Service Montana State University Bozeman, MT 59717
LEAFY SPURGE

Monograph No. 3

$\$ 15.00$
Weed Science Soc. of America 309 West Clark St.

Champaign, IL 61820 


\section{Appendix 15}

LEAFY SPURGE - DISTRIBUTION, BIOLOGY AND CONTROL

Circular 309

Cooperative Extension Service Montana State University

Circular 309

NEBRASKA WEEDS

Revised 1979

Bozeman, MT 59717

State of Nebraska

Department of Agriculture

Weed Division

Lincoln, NE 68509

(402) 472-7211 $\$ 16.95$

PLANTS OF SOUTH DAKOTA GRASSLANDS

(A Photographic Study)

by: J.R. Johnson \& J.T. Nichols

South Dakota State University Agricultural Experiment Station

December 1970 Bulletin \# 566

Brookings, SD 57006

POISONOUS RANGE PLANTS IN MONTANA

Montana State University Cooperative

Extension Service

Wayne C. Leininger, John E. Taylor
MSU Bookstore - $\$ 4.25$

MSU Ext. Publications $\$ 3.90$
The Flower Press 192 Larch Lane Columbia Falls, MT 59912 $\$ 7.95$ or Falcon Press, Box 279 Billings, MT 59103 1-800-582-BOOK (outside MT) 1-800-592-BOOK (inside MT)

RESPONSE OF SELECTED WOODY PLANTS

IN THE U.S. TO HERBICIDES

by: Rodney W. Bovey USDA Agricultural Research Service

Ag Handbook \# 493

Stock \# 001-000-03492-8 \$1.75

SOUTH DAKOTA WEEDS

Last Edition Cost $=\$ 10.00$

Published by: South Dakota State Weed

Control Commission
Supt. of Documents U.S. Govt. Printing Office

Washington, D.C. 20402
Agricultural Ext. Service South Dakota State Univ. Brookings, SD 57006 


\title{
Appendix 15
}

SYSTEMATIC HERBICIDES FOR WEED CONTROL (Phenoxy herbicides, dicamba, picloram

amitrole \& glyphosate)

by: D.L. Klimnman, R.W. Bovey,

E.L. Knake, A.H. Lange,

J.A. Meade, W.A. Skroch,

R.E. Stewart \& D.L. Wyse

December, 1983 AB-BU-2281

THISTLES OF KANSAS

Kansas State Board of Ag
Agricultural Ext. Service University of Minnesota St. Paul, MN 55108 (612) $373-1615$
Plant, Health \& Industry

Division

Topeka, KS 66612

MSU Ext. Publications

Bulletin $323 \$ 3.00$

May, 1985

\author{
Bulletin $323 \$ 3.00$
}

MSU Cooperative Extension Service

VASCULAR PLANTS OF MONTANA, 1984

Mountain West Publishing

Robert D. Dorn

Box 1471

Cheyenne, WY 82003

price $\$ 9.75$

WEED CONTROL MANUAL AND HERBICIDE GUIDE Published by: Ag Consultant and

Meister Publishing Co.

Willoughby, OH 44094

Fieldman

A Meister Publication

1989 6th Edition - Cost ( 5 or more)

$\$ 13.00$ plus postage

WEED IDENTIFICATION PLATES

(Set of 16)

Penn State University

Ag Mail Room

University Park, PA 16802

WEEDS OF ALBERTA

Alberta Environmental

Center

(403) 427-2727

WEEDS OF CANADA

Canadian Gov't Pub.Center

by: C. Frankton \& G.A. Mulligan

First Printing, 1955 (Revised 1970)

Catalogue \#A43-948 \$6.95

Supply \& Services Canada

Huil, Quebec

Canada K1A OS9

WEEDS OF COLORADO

CSU Book Store

Robert L. Zimdahl

Bulletin 521A 


\section{Appendix 15}

WEEDS OF EASTERN WASHINGTON \& ADJACENT Camp-Na-Bor-Lee Assn.
$\begin{array}{ll}\text { AREAS } & \text { Davenport, WA } 99122 \\ \text { by: Gaines and Swan } & \\ \text { Washington State University } & \end{array}$

WEEDS OF THE NORTH CENTRAL STATES

University of Illinois

North Central Regional Research

Publication \# 281

Bulletin \# 722

at Urbana-Champaign

College of Agriculture

Agricultural Exp. Station

Urbana, IL 61801

(217) $333-1000$

WEEDS OF AND POISONOUS PLANTS OF

WYOMING AND UTAH

May 1988

Bulletin \# $498 \$ 15.00$

University of Wyoming

Agricultural Exp. Station

Laramie, WY 82071

(307) 766-3268

WILD WILDFLOWERS OF THE WEST

Edith S. Kinucan and

Penney R. Brons, 1979

Publ. by Kinucan \& Brons

Box 765

Ketchum, ID 83340

Available from bookstores -

$\$ 8.95$

WILDFLOWERS, GRASSES AND OTHER

Available at bookstores

PLANTS OF THE NORTH PLAINS AND

$\$ 6.00$

BLACK HILLS

Theodore Van Bruggen,

Biology Dept.

Univ. of SD, 3rd Ed. - 1983

WEED HANDBOOK (Bound Weed ID Cards) Converse County Weed \& Pest Series $1-30$

Box 728

Wyoming Weed \& Pest Council

$\$ 3.50$ each

Douglas, WY 82633

(307) $358-2775$ 


\section{APR 1 \& IOSI}

Instruction Mamorandum No. WY $-91-239$

Expires $9 / 30 / 92$

$20 \%$

District Managers, Worland, Rawlins and Rock Springs

From:

Deputy State Director, Division of Lands and Renewable Resources

Subject: Guidelines for Coordinated Management of Noxious Weeds in the GYA

Attached for your information and use is a copy of the "Guidelines for

Coordinated Management of Noxious Weeds in the Greater Yellowstone Area.

\section{BILLIE G. DANIELS}

Ariving

1 Attachment:

1 - Binder, "Guidelines for Coordinated Management of Noxious Weeds in the Greater yellowstone Area" (127 pp.)

Distribution
Director (230), Rm 901, Premier Bldg
$\operatorname{SCD}(\mathrm{SC}-325)$
$\mathrm{CP}$
1 w/o atch.
1 w/o atch.
2 w/atch.

PC: WEEDS GYA, JF 


\section{GREATER YELLOWSTONE COORDINATING COMMITTEE}

GYA Team Leader: Custer National Forest

Box 2556

Billings, MT 59103

(406) $657-6361$

Date:

APF 2 '991

SUBJECT: Guidelines for Coordinated Management of Noxious Weeds in the GYA

TO: $\quad$ Ray Brubaker, Director

State of Wyoming

USDI, Bureau of Land Management

2515 Warren Avenue

Cheyenne, WY 82003

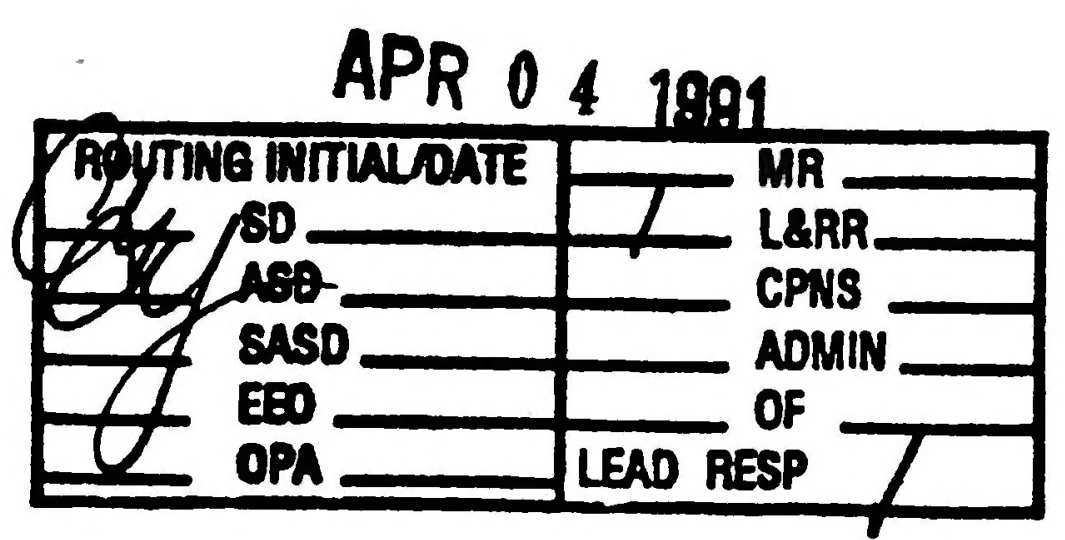

A Memorandum of Understanding (MOU) for Noxious Weed Management was signed by all entities within the Greater Yellowstone Area (GYA) on September 30, 1990. This MOU encourages and formalizes the cooperative relationship necessary for effective management and coordination of Noxious Weed programs among the land managers. The enclosed Guidelines, developed by an Interagency Task Group, will result in increased sharing of expertise, information, resources, and provide a process to improve the efficiency and effectiveness of all weed management programs.

The Guidelines call for an area-wide information brochure on Noxious Weed awareness and establishment of GYA Certification Standards for feeds, mulches, bedding and re-seeding materials.

The Guidelines will be presented at the Noxious Weed Management Short Course for Federal Land Managers within the GYA on Apr 11 22-25 in Bozeman, Montana. Additional Horkbooks can be obtained from Jim Free, Region 2, U.S. Forest Service (303-236-9533).

Thank you for your support and involvement.
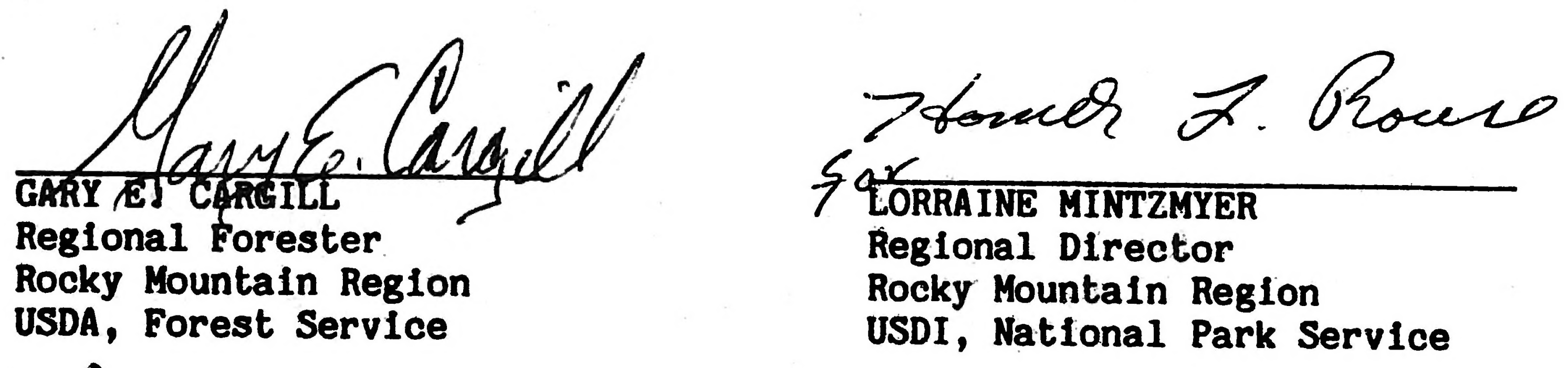

Enclosure 


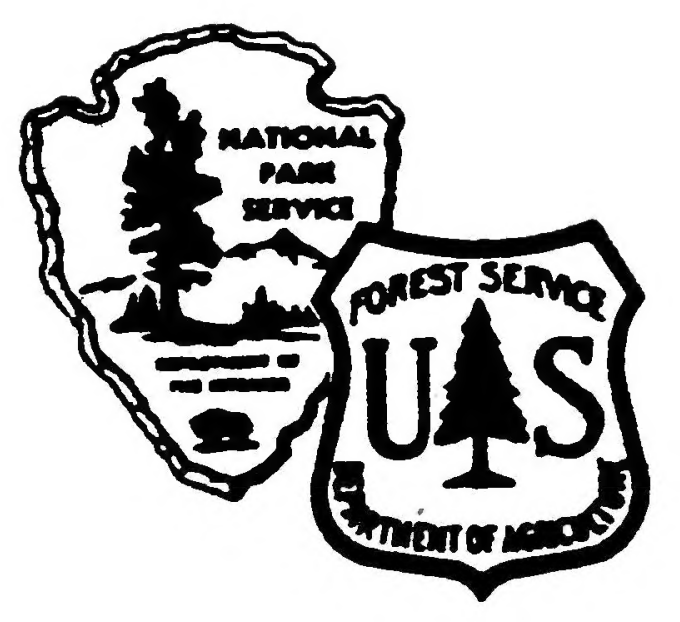

GREATER YELLOWSTONE COORDINATING COMMITTEE

GYA Team Leader: Custer National Fores

Box 2551

Billings, MT 5910:

(406) $657-636$

Date:

APF $2 \cdot 991$

SUBJECT: Guidelines for Coordinated Management of Noxious Weeds in the GYA

TO:

Ray Brubaker, Director
State of Wyoming
USDI, Bureau of Land Management
2515 Warren Avenue
Cheyenne, WY 82003

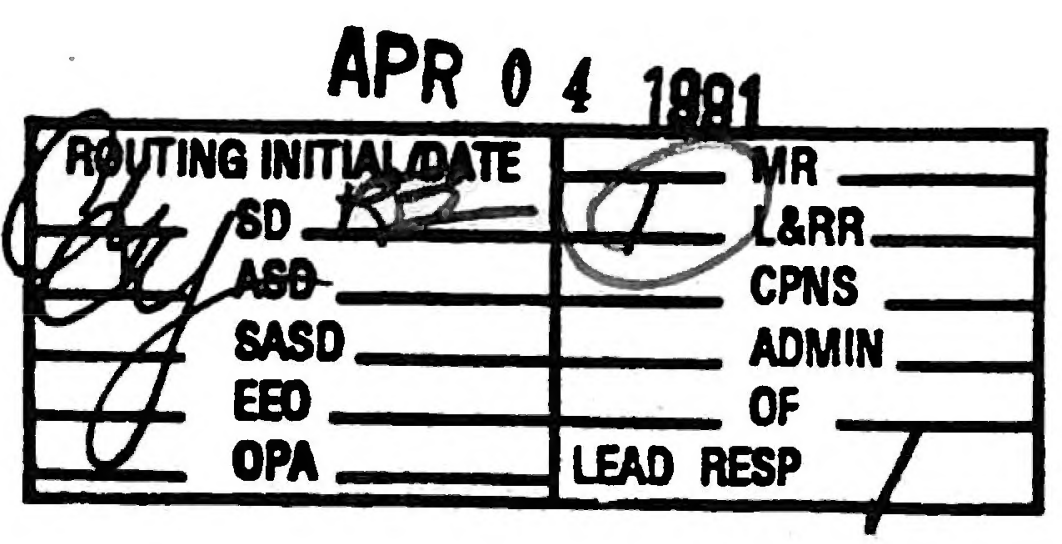

6

A Memorandum of Understanding (MOU) for Noxious Weed Management was signed by all entities within the Greater Yellowstone Area (GYA) on September 30, 1990. This MOU encourages and formalizes the cooperative relationship necessary for effective management and coordination of Noxious Weed programs among the land managers. The enclosed Guidelines, developed by an Interagency Task Group, will result in increased sharing of expertise, information, resources, and provide a process to improve the efficiency and effectiveness of all weed management programs.

The Guidelines call for an area-wide information brochure on Noxious Weed awareness and establishment of GYA Certification Standards for feeds, mulches, bedding and re-seeding materials.

The Guidelines will be presented at the Noxlous Weed Management Short Course for Federal Land Managers within the GYA on Apr 11 22-25 in Bozeman, Montana. Additional workbooks can be obtained from Jim Free, Region 2, U.S. Forest Service (303-236-9533).

Thank you for your support and involvement.
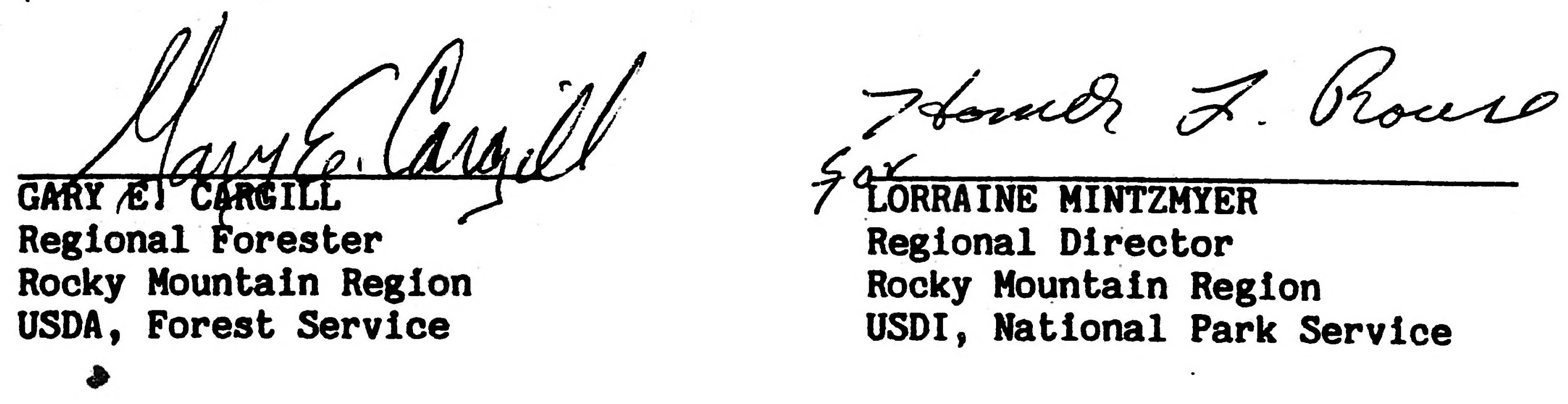

Enclosure 